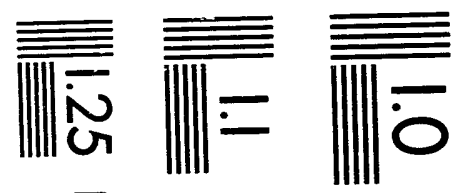

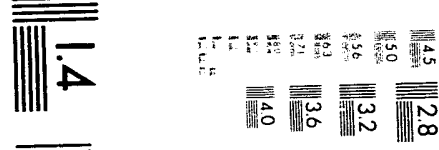

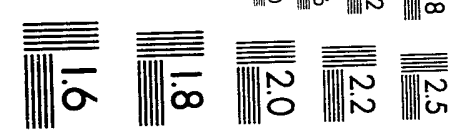



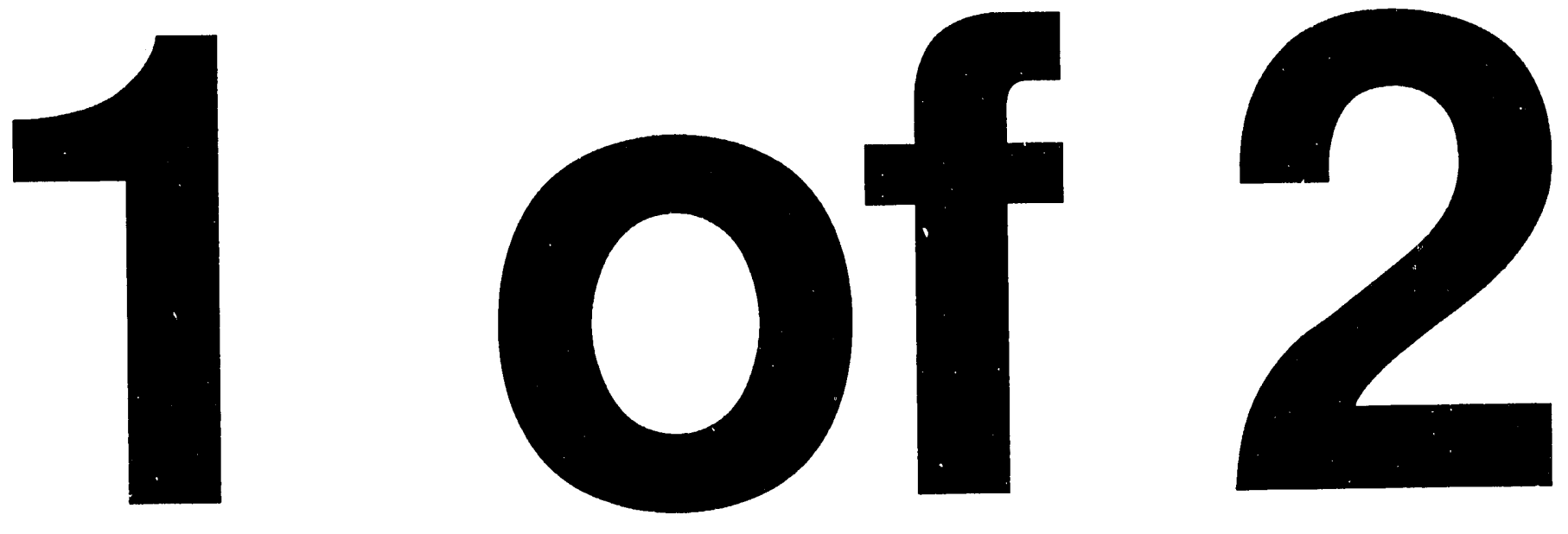


\title{
LONG-TERM SURVEILLANCE PLAN FOR THE \\ LOWMAN, IDAHO, DISPOSAL SITE
}

\section{SEPTEMBER 1993}

\section{This report supersedes report number DOIE/AL-350212.0000}

\author{
Prepared by \\ Jacobs Engineering Group Inc. \\ Albuquerque, New Mexic:o
}

\section{DISCLAIMER}

\begin{abstract}
This report was prepared as an account of work sponsored by an agency of the United States Government. Neither the United States Government nor any agency thereof, nor any of their employees, makes any warranty, express or implied, or assumes any legal liability or responsibility for the accuracy, completeness, or usefulness of any information, apparatus, product, or process disclosed, or represents that its use would not infringe privately owned rights. Reference herein to any specific commercial product, process, or service by trade name, trademark, manufacturer, or otherwise does not necessarily constitute or imply its endorsement, recommendation, or favoring by the United States Government or any agency thereof. The views and opinions of authors expressed herein do not necessarily state or reflect those of the United States Government or any agency thereof.
\end{abstract}




\section{TABLE OF CONTENTS}

Section

Page

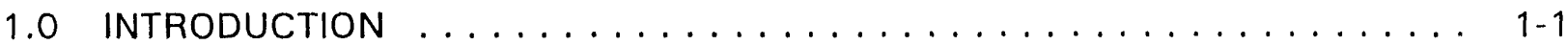

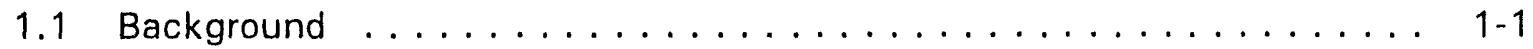

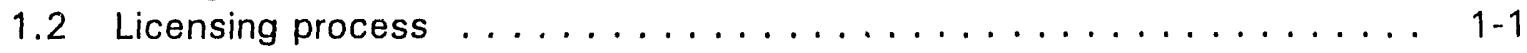

1.2.1 Acquisition ....................... 1-2

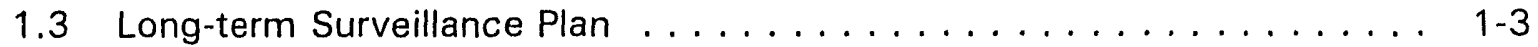

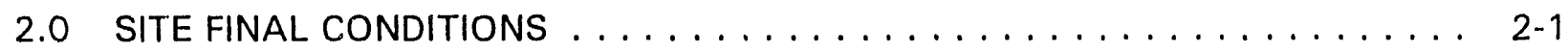

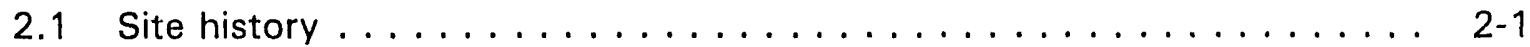

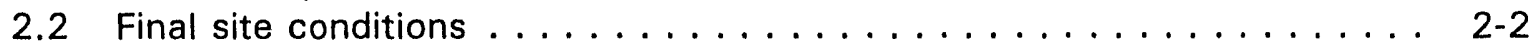

2.2.1 Description and location of disposal site area . . . . . . . . . 2-2

2.2.2 Disposal site access and security ............... 2-2

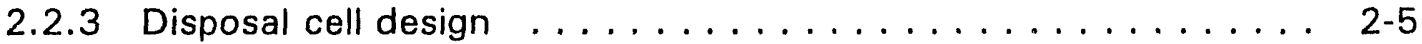

3.0 SITE DRAWINGS AND PHOTOGRAPHS $\ldots \ldots \ldots \ldots \ldots \ldots \ldots \ldots$

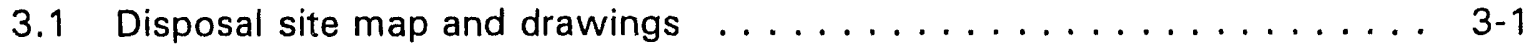

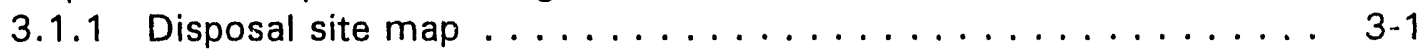

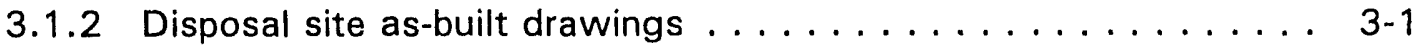

3.2 Site baseline photographs . . . . . . . . . . . . . . . . $3-2$

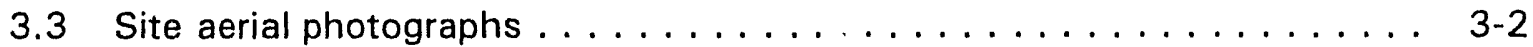

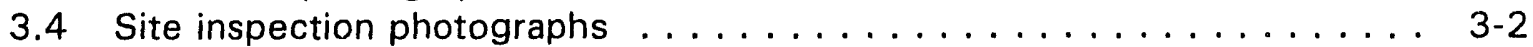

3.4.1 Features to be photographed .............. 3-4

4.0 PERMANENT SITE SURVEILLANCE FEATURES $\ldots \ldots \ldots \ldots \ldots \ldots \ldots$

4.1 Survey monuments . . . . . . . . . . . . . . . . . . . . 4-1

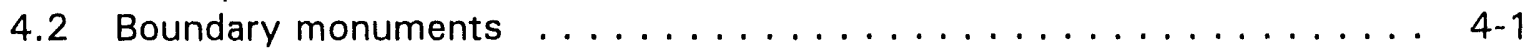

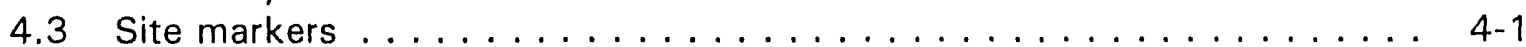

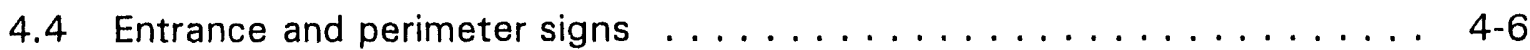

4.5 Settlement plates $\ldots \ldots \ldots \ldots \ldots \ldots \ldots \ldots \ldots \ldots \ldots \ldots$

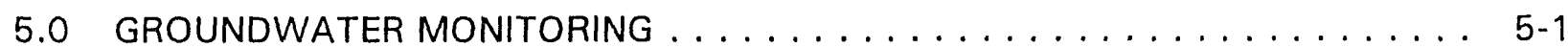

5.1 Groundwater characterization ................... $5-1$

5.1 .1 Hydrostratigraphy ..................... 5-4

5.1 .2 Background groundwater quality ............. $5-4$

5.1.3 Monitored constituents and concentration limits .......... 5-8

5.1 .4 Baseline groundwater quality ............... 5-8

5.2 Groundwater monitoring network ................. 5-10

5.2 .1 Direct monitoring ...................... 5-10

5.2 .2 Monitor well installation and development ........... 5-10

5.2 .3 Indirect monitoring network ................ 5-10

5.3 Groundwater monitoring program ................. 5-10

5.3 .1 Sampling frequency . . . . . . . . . . . . . . . 5-11

5.3.2 Screening monitoring and exceedence validation ........ 5-13

5.3 .3 Evaluative monitoring ................. 5-13 
TABLE OF CONTENTS (Continued)

Section

Page

5.3 .4 Indirect monitoring .................... $5-14$

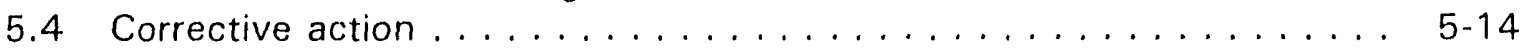

5.5 Data validation and quality assurance $\ldots \ldots \ldots \ldots \ldots \ldots \ldots \ldots$

5.6 Reporting ........................ 5-15

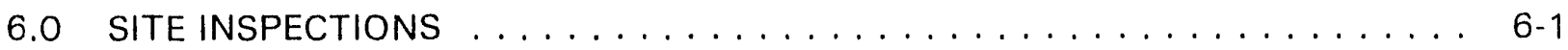

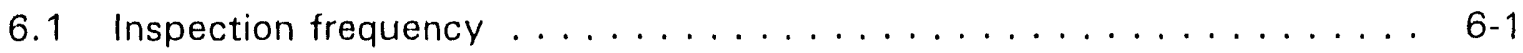

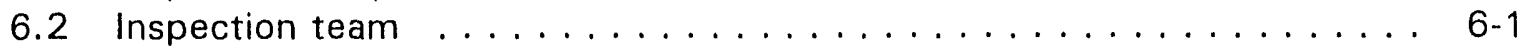

6.3 Preparation for inspection . . . . . . . . . . . . . . . . 6-2

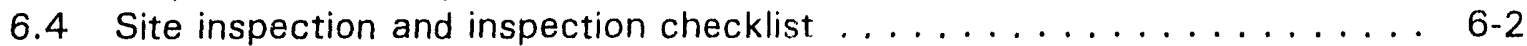

6.4 .1 Off-site areas ....................... 6-3

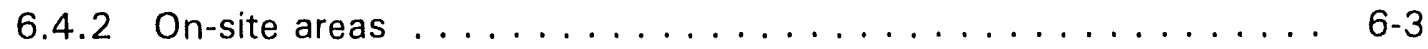

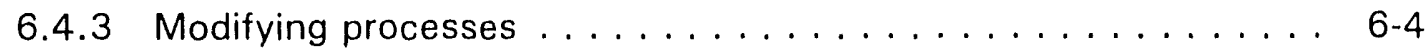

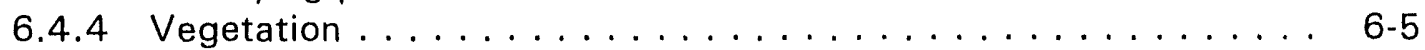

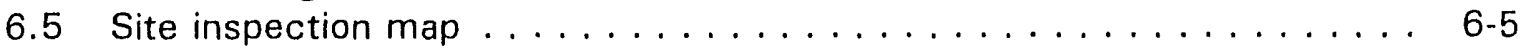

6.6 Reporting requirements ................... $6-5$

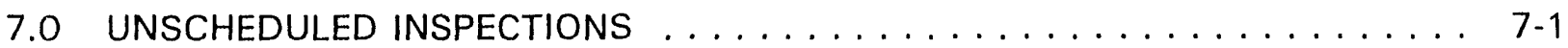

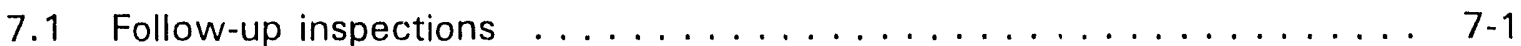

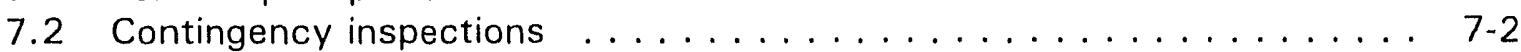

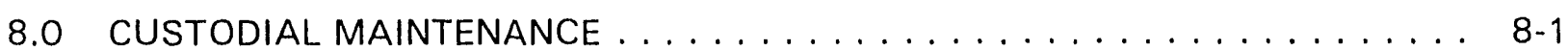

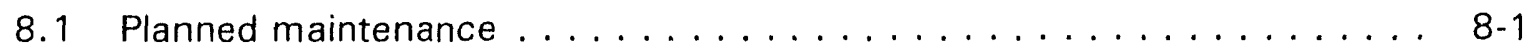

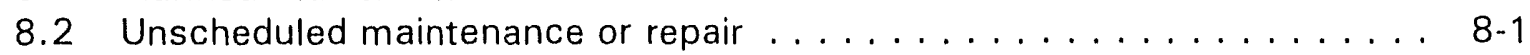

8.3 Certification and reporting requirements $\ldots \ldots \ldots \ldots \ldots \ldots$

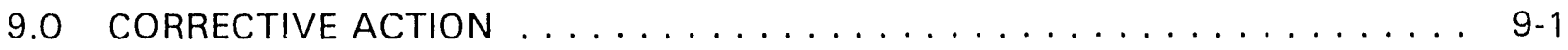

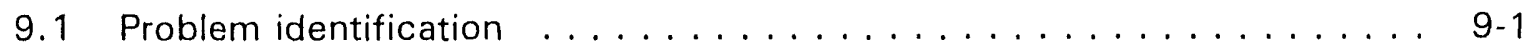

9.2 Certification and reporting requirements . . . . . . . . . . . $9-4$

10.0 RECORD KEEPING AND REPORTING REQUIREMENTS $\ldots \ldots \ldots \ldots \ldots \ldots$. . . . . . $\ldots$

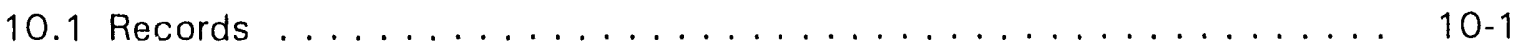

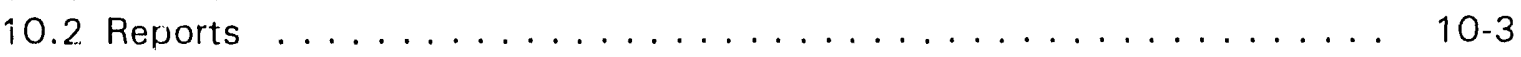

11.0 EMERGENCY NOTIFICATION AND REPORTING . . . . . . . . . . . . . 11 1

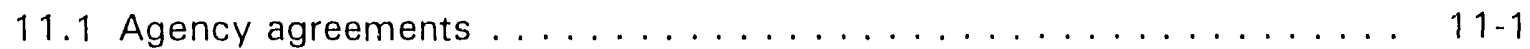

11.2 Unusual occurrences . . . . . . . . . . . . . . . . . 11-1

11.3 Earthquakes ........................... 11-2

11.4 Meteorological events . . . . . . . . . . . . . . . . 11-2

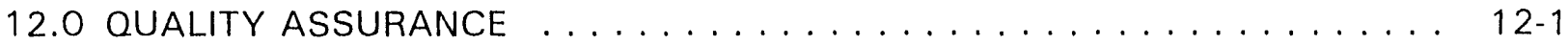


TABLE OF CONTENTS (Concluded)

Section

Page

13.0 PERSONNEL HEALTH AND SAFETY $\ldots \ldots \ldots \ldots \ldots \ldots \ldots \ldots \ldots \ldots \ldots$

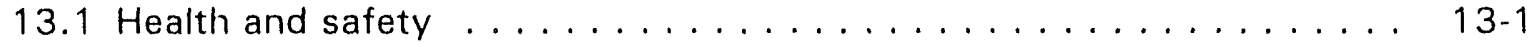

13.1.1 Emergency medical and law enforcement . . . . . . . . . 13-1

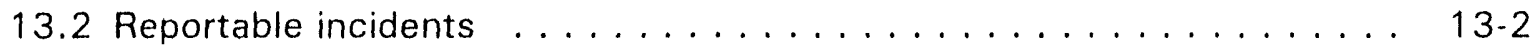

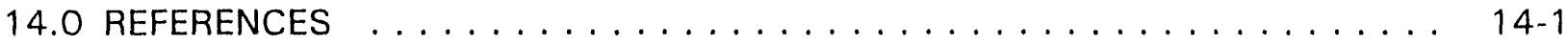

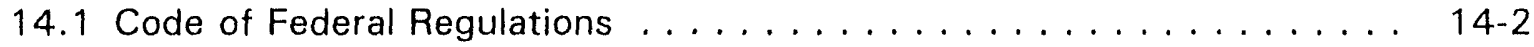

14.2 DOE orders . . . . . . . . . . . . . . . . . . . . 14-2

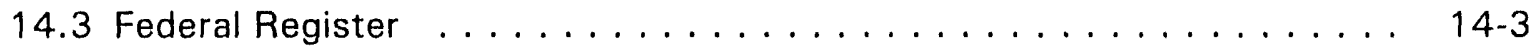

14.4 Public Laws . . . . . . . . . . . . . . . . . . . . . 14-3

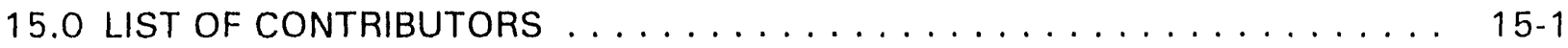

ATTACHMENT 1 SITE OWNERSHIP/CUSTODY DOCUMENTATION

ATTACHMENT 2 NRC CONCURRENCE AND LICENSING DOCUMENTATION

ATTACHMENT 3 PERMANENT SITE FILE INDEX

ATTACHMENT 4 SITE INSPECTION PHOTO LOG

ATTACHMENT 5 INITIAL SITE INSPECTION CHECKLIST

ATTACHMENT 6 AGENCY NOTIFICATION AGREEMENTS 


\section{LIST OF FIGURES}

Figure

Page

2.1 Area map-Lowman, Idaho, disposal site .................. 2-3

2.2 Disposal site location-Lowman, Idaho . . . . . . . . . . . . . . . . . 2-4

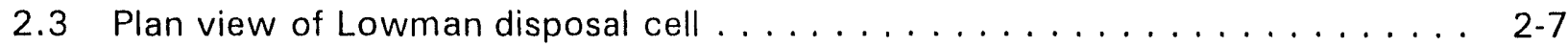

2.4 Cross section of Lowman disposal cell . . . . . . . . . . . . . . . . 2-8

4.1 Survey/boundary monument-Lowman, Idaho, disposal site . . . . . . . . . 4-3

4.2 Boundary monument-Lowman, Idaho, disposal site . . . . . . . . . . . . . . 4-4

4.3 Site marker incised message - Lowman, Idaho, disposal site . . . . . . . . . . . 4-5

4.4 Site marker specifications - Lowman, Idaho, disposal site . . . . . . . . . . . 4-7

4.5 Perimeter sign-Lowman, Idaho, disposal site . . . . . . . . . . . . . . . . 4-8

4.6 Entrance sign-Lowman, Idaho, disposal site . . . . . . . . . . . . . . 4 4-9

5.1 Geologic cross section-Lowman disposal site near Lowman, Idaho . . . . . . 5-5

5.2 Potentiometric map of alluvium/weathered granodiorite, April 1991 . . . . . . 5-6

5.3 Plan view of disposal cell, and groundwater monitoring wells, Lowman disposal site near Lowman, Idaho ... . . . . . . . . . . . . . . . . . . . . . . . 5-7

5.4 UMTRA Project groundwater monitoring program . . . . . . . . . 5-12

9.1 Corrective action-UMTRA Project long-term surveillance program . . . . . . 9-2

9.2 Key elements in the corrective action process . . . . . . . . . . . . 9-3

\section{LIST OF PLATES}

Plate 1 Disposal site map 


\section{LIST OF TABLES}

Table

Page

2.1 Lowman disposal site access key holders . . . . . . . . . . . . 2-5

3.1 Aerial photography specifications for the Lowman disposal site . . . . . . . . 3-3

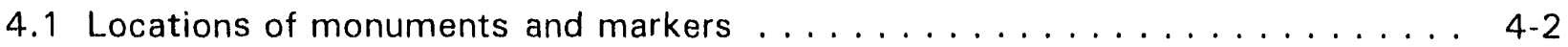

5.1 List of monitored constituents and their statistical maximum background groundwater concentrations .................... 5-3

5.2 Statistical summary of background groundwater quality . . . . . . . . . . 5-9

5.3 Groundwater monitoring well network, Lowman, Idaho, disposal site . . . . . 5-11 


\section{LIST OF ACRONYIVS AND ABBREVIATIONS}

\begin{tabular}{|c|c|}
\hline Acronym & Definition \\
\hline ac & acre \\
\hline BLM & Bureau of Land Management \\
\hline CFR & U.S. Code of Federal Regulations \\
\hline $\mathrm{cm}$ & centimeter \\
\hline $\mathrm{cm} / \mathrm{s}$ & centimeter per second \\
\hline DOE & U.S. Department of Energy \\
\hline EA & environmental assessment \\
\hline EPA & U.S. Environmental Protection Agency \\
\hline $\mathrm{ft}$ & feet \\
\hline $\mathrm{ft}$ & foot \\
\hline GJPO & Grand Junction Projects Office \\
\hline ha & hectare \\
\hline in & inch \\
\hline $\mathrm{km}$ & kilometer \\
\hline LTSP & long-term surveillance plan \\
\hline $\mathrm{m}$ & meter \\
\hline$m^{3}$ & cubic meters \\
\hline MCL & maximum concentration limit \\
\hline $\mathrm{mi}$ & mile \\
\hline $\mathrm{mg} / \mathrm{L}$ & milligrams per liter \\
\hline NRC & U.S. Nuclear Regulatory Commission \\
\hline NWS & National Weather Service \\
\hline $\mathrm{pCi} / \mathrm{L}$ & picocuries per liter \\
\hline POC & point of compliance \\
\hline QA & quality assurance \\
\hline QC & quality control \\
\hline RAP & remedial action plan \\
\hline SOP & standard operating procedure \\
\hline SOS & stabilized on site \\
\hline TAC & Technical Assistance Contractor \\
\hline TAD & Technical Approach Document \\
\hline TDS & total dissolved solid \\
\hline TER & Technical Evaluation Report \\
\hline UMTRA & Uranium Mill Tailings Remedial Action \\
\hline UMTRCA & Uranium Mill Tailings Radiation Control Act \\
\hline USACE & U.S. Army Corps of Engineers \\
\hline USGS & U.S. Geological Survey \\
\hline $\begin{array}{l}\text { WSAP } \\
v d^{3}\end{array}$ & $\begin{array}{l}\text { water sampling analysis plan } \\
\text { cubic vards }\end{array}$ \\
\hline
\end{tabular}




\subsection{INTRODUCTION}

The long-term surveillance plan (LTSP) for the Lowman, Idaho, Uranium Mill Tailings Remedial Action (UMTRA) Project disposal site describes the surveillance activities for the Lowman disposal cell. The U.S. Department of Energy (DOE) will carry out these activities to ensure that the disposal cell continues to function as designed. This preliminary final LTSP is being submitted to the U.S. Nuclear Regulatory Commission (NRC) as a requirement for issuance of a general license for custody and long-term care for the disposal site. The general license requires that the disposal cell be cared for in accordance with the provisions of this LTSP. The LTSP documents whether the land and interests are owned by the United States or an Indian tribe, and describes, in detail, how the long-term care of the disposal site will be carried out through the UMTRA Project long-term surveillance program. The Lowman, Idaho, LTSP is based on the DOE's Guidance for Implementing the UMTRA Project Long-term Surveillance Program, (DOE, 1992).

\subsection{BACKGROUND}

Title I of the Uranium Mill Tailings Radiation Control Act (UMTRCA) of 1978 (Public Law 95-604, 1978), and subsequent amendments authorized the DOE to perform remedial actions at 24 inactive uranium mill tailings sites to reduce the potential public health impacts from the unstabilized residual radioactive materials in and around the uranium mill tailings. The Lowman, Idaho, uranium mill radioactive sands site in Boise County was one of the 24 sites identified for remediation in the UMTRCA. The DOE and the state of Idaho entered into a cooperative agreement under the UMTRCA, setting forth the terms and conditions whereby the remedial action was conducted (DOE Cooperative Agreement No. DE-FCO4-85AL20535). The NRC and the state of Idaho concurred in July 1991 and September 1991, respectively, with DOE's plan for the Lowman site remedial action, which was described and evaluated in the environmental assessment (EA) (DOE, 1991a) and remedial action plan (RAP) (DOE, $1991 \mathrm{~b}$ ) prepared by the DOE. The NRC's review and evaluation of the DOE's plans for remedial action are contained in their Final Technical Evaluation Report (TER) (NRC, 1991).

\subsection{LICENSING PROCESS}

The NRC has developed regulations (10 CFR 40.27) for issuing a general license [effective November 29, 1990 (55 FR 45591)] for the long-term care of DOE UMTRA (Title I) disposal sites, including the Lowman disposal site. The license is available only to the DOE (or any successor Federal agency designated by the President) and has no termination date. The purpose of this general license is to ensure that the UMTRA disposal sites will be cared for in such a manner to protect the public health and safety and the environment upon completion of remedial actions. A disposal site comes under the general license after the NRC concurs that the remedial action is complete at that site and formally accepts a site-specific LTSP that meets the requirements of 10 CFR 40.27. Because the Lowman 
processing site radioactive sands were stabilized on site, the NRC licensing process would normally proceed in two phases: surface remediation Phase I, and the groundwater remediation Phase II. The first phase would allow the DOE to complete all remedial actions at the processing sites, except for restoration of the groundwater. This includes complying with the proposed groundwater protection standards addressing the design and performance at the disposal site. Under NRC regulations, the general license will become effective when the NRC concurs in the DOE's certification that the remedial action is complete and accepts the Lowman disposal site LTSP. When the NRC concurs in the DOE's determination that groundwater restoration activities at the processing sites under 40 CFR 192 Subparts $A$ through $C$ have been completed, the second phase of the general license will be issued. The Lowman disposal site does not have groundwater contamination. As a result, one phase of licensing will occur at the site. The NRC is currently reviewing the Draft Completion Report for the Lowman remedial action project. Until the NRC completes their review of the Draft Completion Report, the Lowman site will remain in prelicensing status. Following NRC acceptance of the final LTSP and certification report, the licensing process for the Lowman disposal site will be completed.

\subsubsection{Acquisition}

The state of Iciaho acquired the larger portion of the site, 37 acres (ac) [15 hectares (ha) ], from NWI Land Management Corporation via quitclaim deed, which conveyed the land in fee simple title. The land acquired from NWI Land Management Corporation was to remain with the state of Idaho until the remedial action project at Lowman was completed. Once completed, transfer of the land to the custody of the Federal Government, under the jurisdiction of the DOE, is to take place.

The state of Idaho also acquired a parcel of land by purchase from the U.S. Forest Service, under the Small Tracts Act. The parcel, consisting of 4.32 ac (1.75 ha), was required for the final disposal cell design and provided a buffer zone to the disposal cell area. The subsurface mineral rights were acquired via transfer of jurisdiction from the Bureau of Land Management (BLM). A legal description of the boundaries of the Lowman disposal site is provided in Attachment 1.

Remedial action at the Lowman site, under Subpart A requirements of the U.S. Environmental Protection Agency's (EPA) Standards for Remedial Actions at Inactive Urarium Processing Sites (40 CFR 192), was completed on June 16, 1992. No further remedial action is needed under Subparts $A$ through $C$ of 40 CFR 192. Cleanup of Contaminated Groundwater, as no groundwater contamination exists at the site (DOE, 1991b). Under the terms of the cooperative agreement, the state of Idaho will now transfer title to the Lowman disposal site to the DOE. The DOE, or another Federal agency that the President may designate, will have perpetual custody of the Lowman disposal site and permanent right of entry to undertake such monitoring, maintenance, and emergency measures as may be necessary to protect public health and safety and the environment. 
The disposal site will be restricted from unauthorized entry and public use.

\subsection{LONG-TERM SURVEILLANCE PLAN}

This document describes the long-term surveillance program to be implemented at the L.owman site to ensure that the disposal cell continues to perform as designed. The plan is based on DOE's Guidance for Implementing the UMTRA Project Longterm Surveillance Program (DOE, 1S92).

This LTSP rieets the requirements under 10 CFR 40.27 by addressing the following:

- Site description and ownership.

- Description of final site conditions.

- Site inspection procedures and personnel.

- Custodial maintenance and corrective action programs.

- Record keeping and reporting.

- Quality assurance (QA).

- Emergency response. 


\subsection{SITE FINAL CONDITIONS}

\subsection{SITE HISTORY}

The Lowman mill site was used to recover columbite/euxenite and monazite concentrates between 1955 and 1960. During the life of the mill, approximately 200,000 tons $(180,000$ tonnes $)$ of dredge concentrates were processed. Final concentrates were sent to the Mallinckrodt Chemical works at Hematite, Missouri, where columbium and tantalum pentoxides, uranium oxicie, rare-earth elements, titanium, and thorium-iron residues were produced. Radioactive sands with low leachability characteristics remained at the Lowman site.

The remedial action was initiated at the Lowman uranium mill radioactive sands disposal site in 1991 to stabilize the radioactive sand piles. Specifically, the principal feature of the remedial action was the consolidation and stabilization of the residual radioactive materials from the sand piles, mill yard, ore storage area, windblown/waterborne areas, settling ponds, and vicinity properties on top of the existing piles of black sands, located in the southern portion of the site. The disposal site boundary is not fenced; however, access is partially restricted by a gate across the access road.

Concurrence from the NRC on the RAP was received on July 31,1991 (Attachment 2).

The remedial action at the Lowman site was completed in 1992. A total of 129,400 cubic yards (yd ${ }^{3}$ ) $\left[98,950\right.$ cubic meters $\left.\left(m^{3}\right)\right]$ of contaminated materials were stabilized onsite in a disposal cell covering 8.2 ac $(3.3 \mathrm{ha})$ within the 37 -ac (15-ha) disposal site (MKF, 1992).

Under provisions of 10 CFR 40.27 for long-term surveillance and maintenance, groundwater compliance monitoring will be part of the long-term surveillance program. Currently, no groundwater contamination exists at the disposal site, and no groundwater restoration will be required.

When the general license becomes effective for the Lowman disposal site after NRC concurrence on the completion of the surface remedial action and approval of the LTSP, the long-term surveillance program will be the responsibility of the DOE Grand Junction Projects Office (GJPO), Grand Junction, Colorado. The programmatic transfer will occur within 30 days of notification by the NRC that the license is in effect. The DOE will remain the responsible Federal agency, unless a successor agency is designated by the President of the United States. 


\subsection{FINAL SITE CONDITIONS}

\subsubsection{Description and location of disposal site area}

The Lowman site is located in Boise County, Idaho, approximately 73 miles (mi) 1120 kilometers $(\mathrm{km})]$ northeast of Boise and $0.5 \mathrm{mi}(0.8 \mathrm{~km})$ northeast of the village of Lowman. The 37-ac (15-ha) former mill site is located in Section 27, Township 9 North, Range 7 East, Boise Principal Meridian, at latitude $44^{\circ} 05^{\prime} 09^{\prime \prime}$ north and longitude $115^{\circ} 36^{\prime} 30^{\prime \prime}$ west (Figure 2.1).

The Lowman site !ies at an elevation of approximately 3850 feet $(\mathrm{ft}) \mid 1200$ meters $(\mathrm{m}) /$ on terrace deposits, $80 \mathrm{ft}(24 \mathrm{~m})$ above and to the east of Clear Creek and its associated floodplain. The total site acreage is approximately 42 ac (17 ha), and it is bound on the south by State Highway 21, on the west by Clear Creek, and on the north and east by U.S. Forest Service land. The site consists of several piles of radioactive sands, an ore storage area, abandoned mill buildings (concrete structures onlyl, two settling ponds, and windblown/waterborne contaminated areas (MKF, 1992).

The area in the vicinity of the disposal site is characterized by steep, heavily wooded terrain, and is within the Boise National Forest. The land in the surrounding area of the disposal site is used for recreation, grazing, logging, and mining (DOE, 1991a).

A Class III cultural resource survey of approximately 65 ac (26 ha) at and around the Lowman site was conducted in May 1987. No historic or prehistoric cultural resources are known to exist at the radioactive sands site (DOE, 1991a; BRR, 19871 .

Figure 2.2 provides a detailed view of the disposal site and vicinity. Additionally, the Lowman site can be located using the following directions:

- Proceed $0.5 \mathrm{mi}(0.8 \mathrm{~km})$ north on State Highway 21 from the south end of the Highway Bridge across the South Fork of the Payette River in Lowman.

- Turn left onto the site access road (immediately after crossing Clear Creek).

- Proceed $0.1 \mathrm{mi}(0.2 \mathrm{~km})$ to the gate across the site access road.

\subsubsection{Disposal site access and security}

The state of Idaho will be notified periodically concerning DOE site visits so that the state of Idaho may choose to send observers. Keys to the lock on the disposal site security gate are held by the state of idaho. Additionally, keys are kept by the DOE UMTRA Project Manager; the Technical Assistance Contractor (TAC) UMTRA Project Manager; and the Supervisory, General Engineer, GJPO (Table 2.1). 


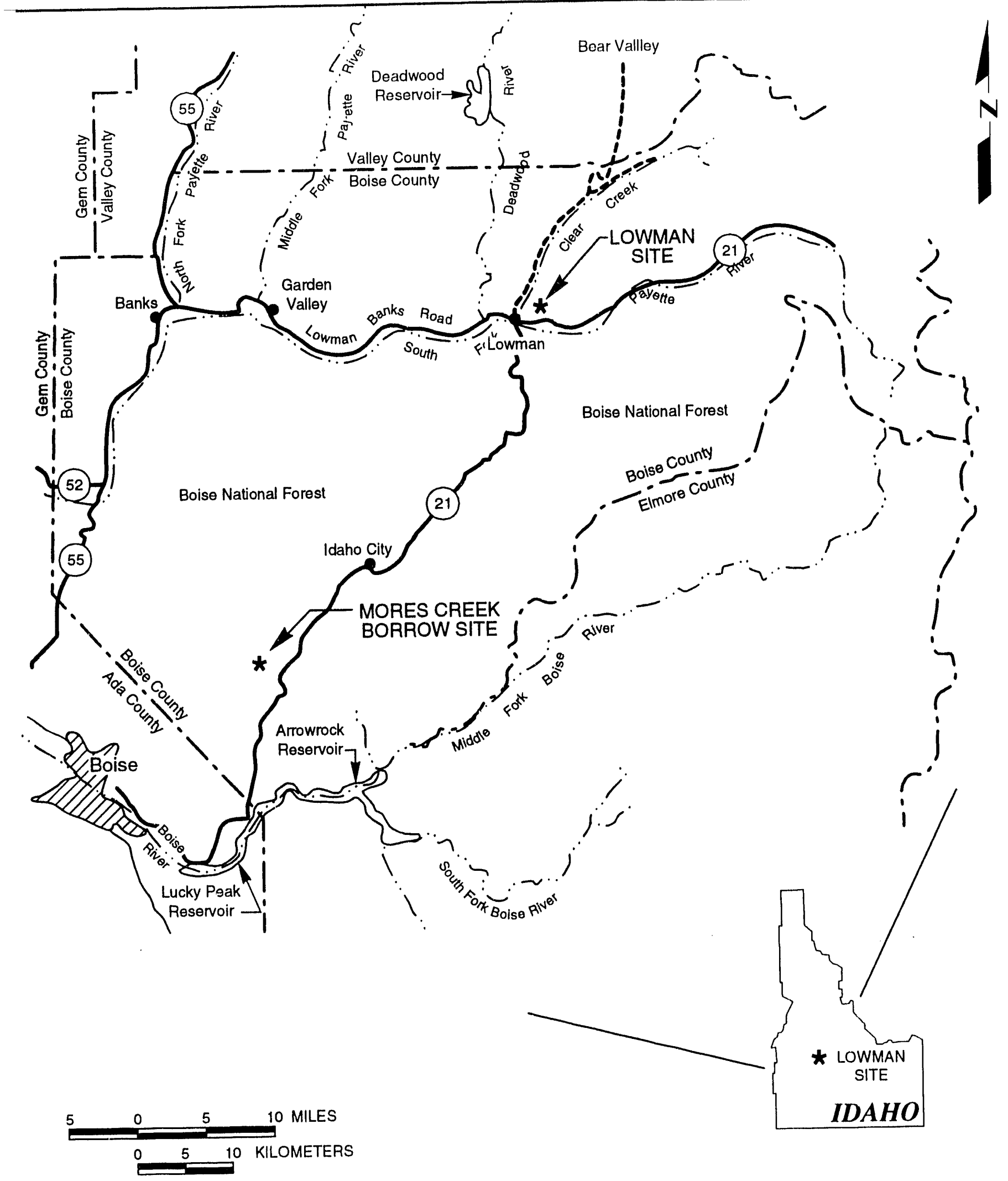

FIGURE 2.1

AREA MAP

LOWMAN, IDAHO, DISPOSAL SITE

(DOE, 1991a)

LOWLTSP 


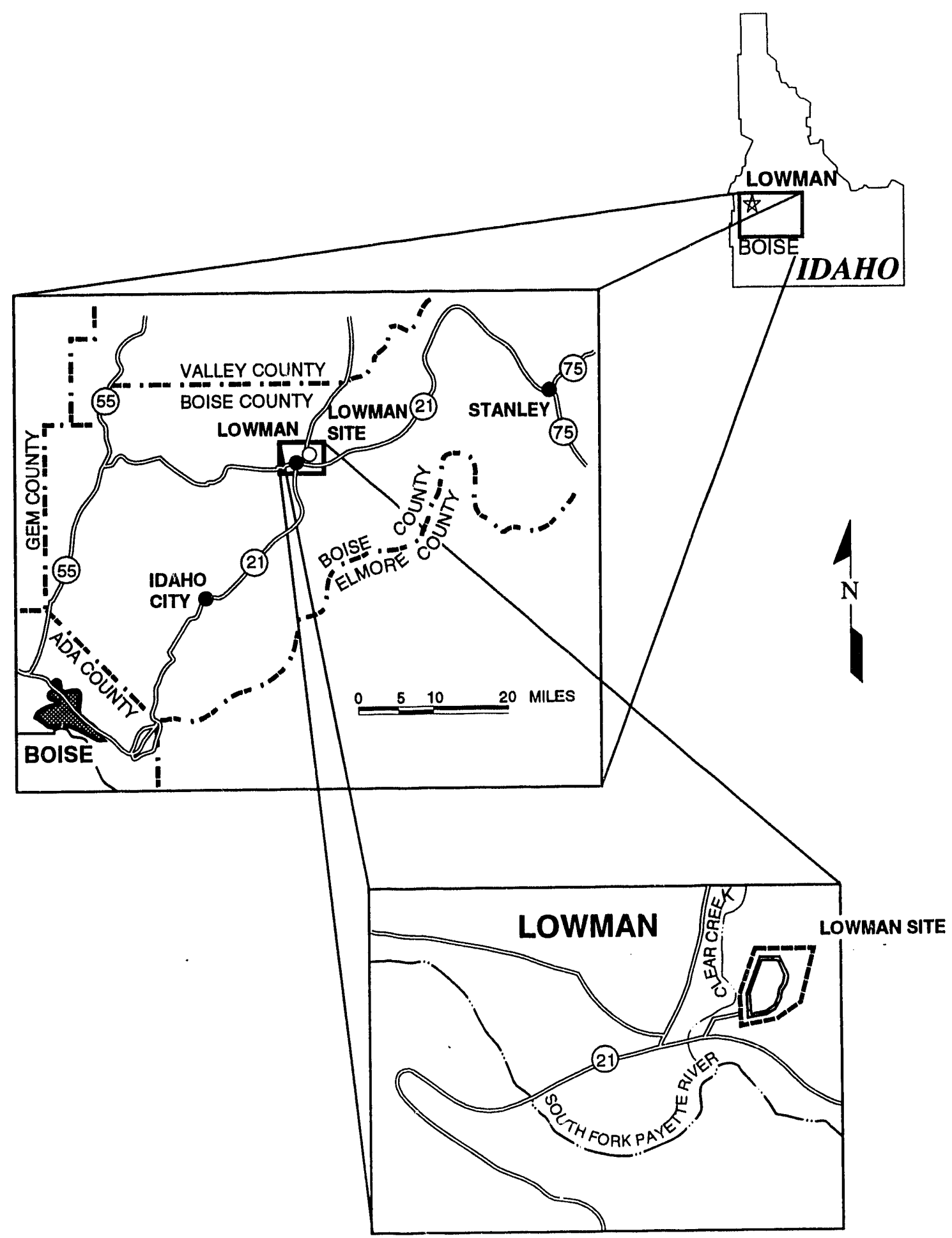

FIGURE 2.2 
Table 2.1 Lowman disposal site access key holders

\begin{tabular}{|c|c|c|}
\hline Title and current contract & Telephone & Address \\
\hline $\begin{array}{l}\text { DOE UMTRA Project Manager } \\
\text { (Albert Chernoff) }\end{array}$ & $(505) 845-4022$ & $\begin{array}{l}\text { U.S. Department of Energy } \\
\text { UMTRA Project Office } \\
2155 \text { Louisiana NE } \\
\text { Suite } 4000 \\
\text { Albuquerque, NM } 87110\end{array}$ \\
\hline $\begin{array}{l}\text { TAC UMTRA Project Manager } \\
\text { (Roger Nelson) }\end{array}$ & $(505) 888-1300$ & $\begin{array}{l}\text { Jacobs Engineering Group } \\
2155 \text { Louisiana NE } \\
\text { Suite } 10000 \\
\text { Albuquerque, NM } 87110\end{array}$ \\
\hline $\begin{array}{l}\text { Supervisory General Engineer } \\
\text { GJPO } \\
\text { (Joe Virgona) }\end{array}$ & (303) 248-6019 & $\begin{array}{l}2597 \text { B } 3 / 4 \text { Road } \\
\text { Grand Junction, CO } 81503\end{array}$ \\
\hline
\end{tabular}

The Lowman disposal site is visible from State Highway 21. Two entrance signs and 20 perimeter signs are located around the site to inform the public of the site's function and ownership (Section 4.0). No security fence or stock fence exist at this site. Site access is controlled by a locked gate across the access road that should effectively preclude vehicular intrusion. Human intrusion, vandalism, and livestock grazing are not expected to be problems. If any of the above issues become problems, site security will be reevaluated.

The scheduled site inspections (Section 6.0) will monitor the effectiveness of the security measures at the Lowman, Idaho, disposal site. The DOE 24-hour telephone number on the two entrance signs (Section 4.0) and agreements with local agencies to notify the DOE in the event of an emergency or breach of site integrity (Section 11.0) will provide additional security measures.

\subsubsection{Disposal cell design}

The completed disposal cell has sideslopes of 20 percent (five horizontal to one verticall and a topslope of 10 percent. The radioactive sands and contaminated materials were covered with a 1.5 -foot $(\mathrm{ft})(0.46-\mathrm{m})$ thick layer of compacted earth as a radon barrier to inhibit radon emanation, then covered with a $0.5-\mathrm{ft}(0.15-\mathrm{m})$ thick layer of free-draining, sandy bedding material and riprap rock material for erosion protection. The disposal cell covers approximately 9 ac $(4 \mathrm{hal}$ ). Some reshaping of sands was performed around the perimeter of the pile. The stabilized disposal cell is surrounded by a rock apron. The apron protects the cell from potential gully intrusion. The apron is 3 to $6 \mathrm{ft}(0.9 \mathrm{~m}$ to $1.8 \mathrm{~m})$ thick and 25 to 
$35 \mathrm{ft}(8$ to $11 \mathrm{~m})$ wide. A plan view of the disposal cell is provided in Figure 2.3. A cross section of the apron is shown in Figure 2.4.

The surface conditions of the disposal cell will be monitored during the yearly inspections to determine if the disposal cell and erosion protection measures are performing as designed. Guidelines to be followed when inspecting the disposal cell and criteria for corrective actions or repairs are as follows:

- Crest-Observations will be made in all directions for any features that are anomalous or unexpected and that may require a closer inspection. A walk around the edge and along diagonal transects of the crest will be made. Additional transects, at approximately 50-yd (46-m) intervals, will be walked along the sideslopes. A search will be made for evidence of any differential settling, subsidence, or cracks. The rock cover will be examined for evidence of rapid deterioration. Individual rocks will be examined for excessive fracturing, oxidation, or other signs of deterioration. Areas of sand accumulation and volunteer plant growth will be noted.

- Slopes-Modifications to the disposal site are most likely to occur on the lower portions of the slopes. Therefore, a careful examination at the toe of the slope will be a key part of this inspection. Settlement or sliding, although highly unlikely, will be apparent by the presence of bulges and depressions, cracks, or scarps. Any localized change in color (e.g., "stained" vegetation) or concentration of vegetation will be described and examined for evidence of seepage. During the inspections, the slopes will be examined for evidence of animal intrusion, burrowing, changes in vegetation, and human activity. Cattle, sheep, or wildlife may inadvertently wander onto the site, but they are not likely to remain.

- Drainage ditch and drainage channels-The inspectors will walk along the entire length of each channel to determine whether the channels have been functioning and can be expected to continue to function as designed. The channels and sideslopes will be examined for evidence of erosion or sedimentation, slides, incipient erosion channels, debris, or growing vegetation. The sideslopes will also be examined for evidence of piping or burrowing by animals, which could lead to sloughing of material into the channel. The condition of the drainage ditches and swales will then be compared to the design criteria outlined in the Morrison-Knudsen engineers Final Design and Engineering Calculations, Volume IV of the Lowman site RAP (DOE, $1991 \mathrm{~b}$ ). 


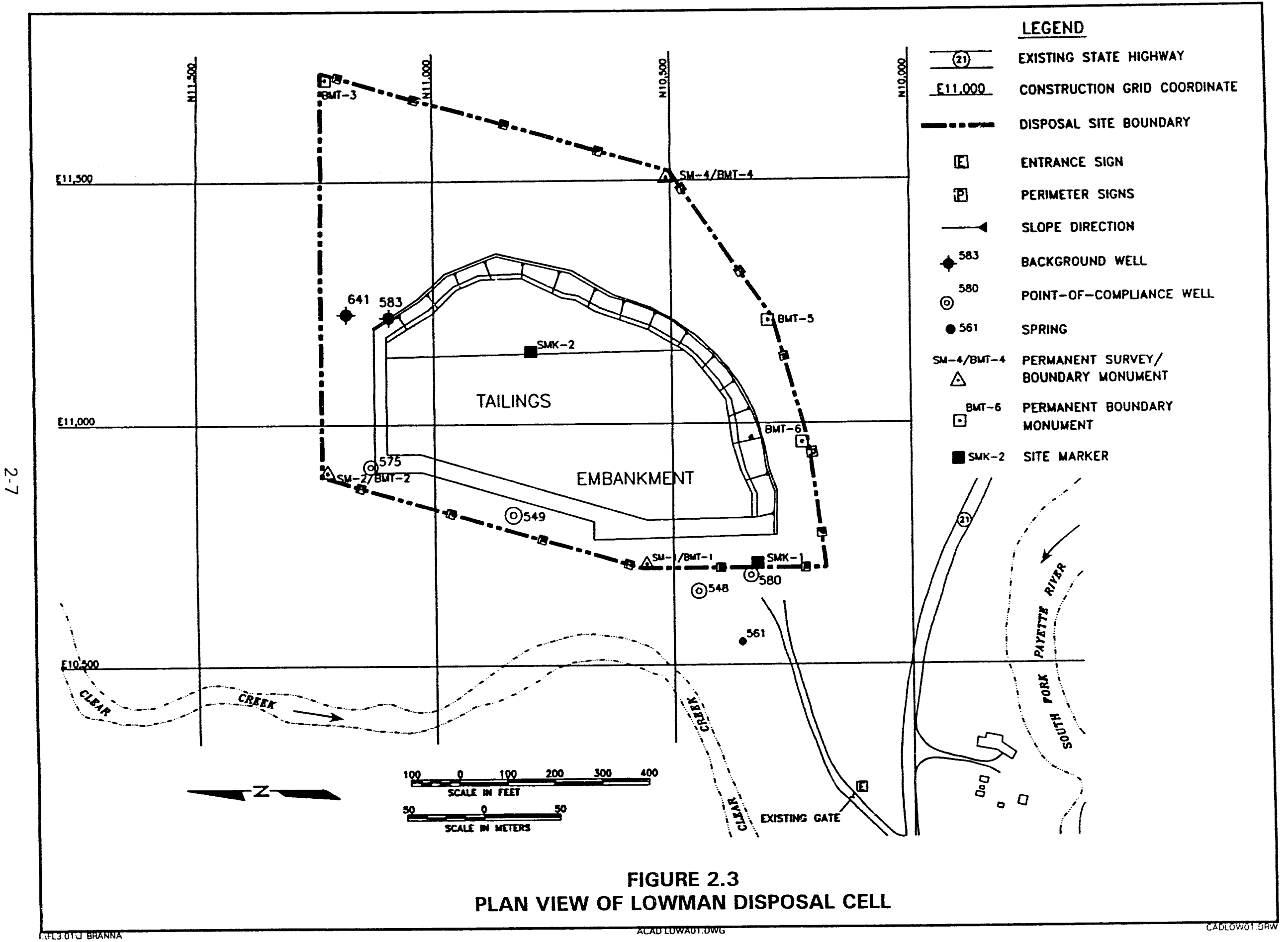



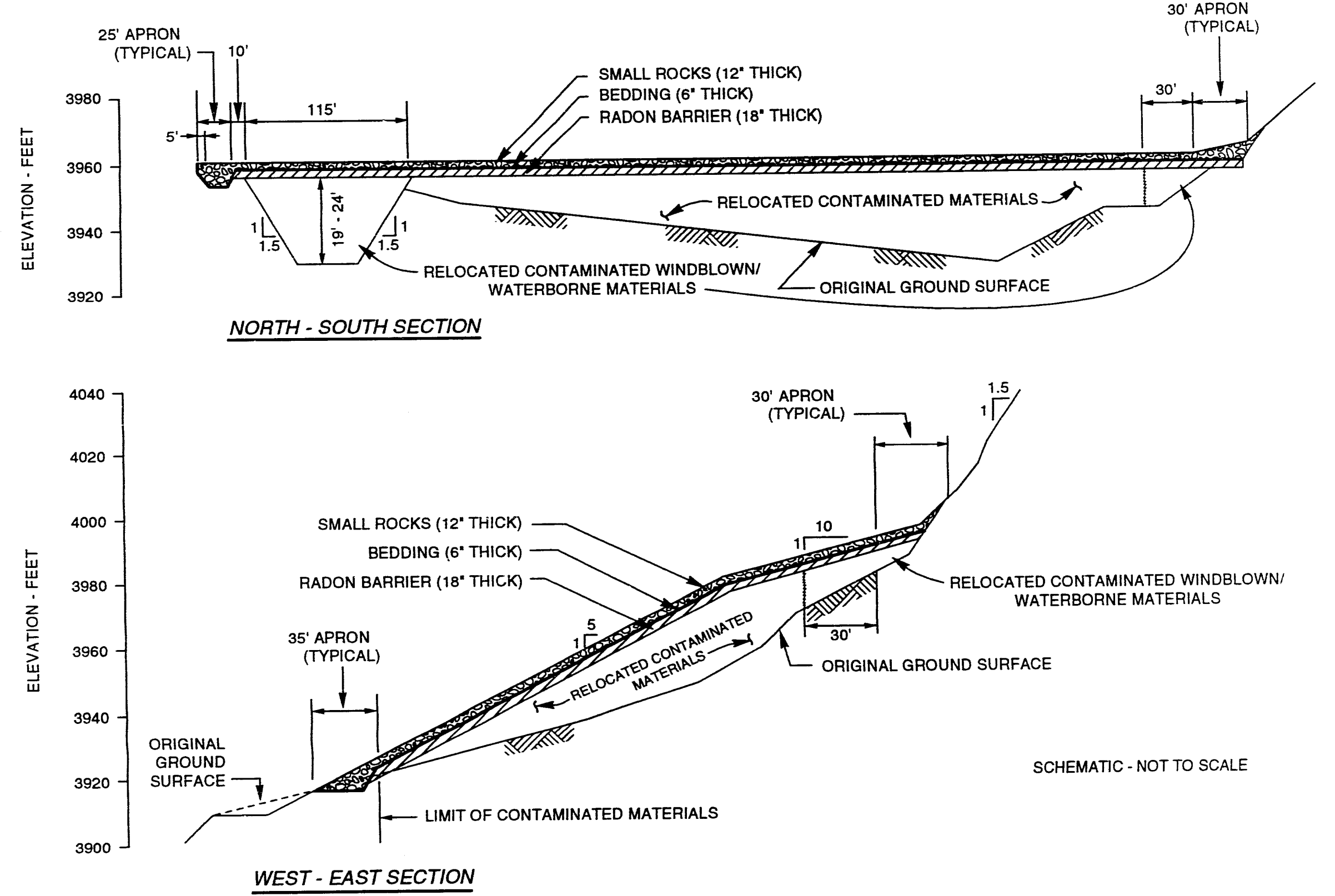

FIGURE 2.4 CROSS SECTION OF LOWMAN DISPOSAL CELL 


\subsection{SITE DRAWINGS AND PHOTOGRAPHS}

At the completion of remedial action, disposal site as-built conditions were documented with as-built drawings and photographs (MFK, 1992). This information will be used to illustrate baseline conditions against which future conditions of the disposal site can be compared.

\subsection{DISPOSAL SITE MAP AND DRAWINGS}

A site atlas will be prepared that includes a disposal site map. The site atlas will be updated, as necessary, after each site inspection. All of the drawings are archived in the permanent site file as indicated in the site file index (Attachment 3).

\subsubsection{Disposal site map}

A disposal site map, including topographic features for the Lowman site, is included as Plate 1. The map identifies the following site features:

- Disposal site plus an area of $0.25 \mathrm{mi}(0.4 \mathrm{~km})$ around the site perimeter.

- Scale 1 in $=200 \mathrm{ft}(1 \mathrm{~cm}=24 \mathrm{~m})$.

- Disposal site boundary.

- Disposal cell.

- State plane coordinates.

- Groundwater monitoring wells.

- Drainage system.

- Site gate.

- Site access road.

The Lowman disposal site map is presented in Plate 1. If the disposal site map is updated, the revised map will include the year of revision and the revision number. The disposal map will serve as the base map for site inspections (Section 6.5). A new, separate inspection map will be prepared after each inspection. Each site inspection map will indicate the year of the inspection and the type of inspection. All site base maps and periodic site inspection maps will become part of the permanent Lowman site file.

\subsubsection{Disposal site as-built drawings}

Upon completion of the remedial action at the Lowman disposal site, as-built drawings were made to illustrate the final disposal cell construction and final site conditions. These drawings are included in the Lowman Draft Completion Report (MKF, 1992) and are in the permanent site file. As-built drawings are to be used to document changes in physical site conditions or changes to the disposal cell over time or for developing corrective action plans, if required. 


\subsection{SITE BASELINE PHOTOGRAPHS}

A photographic record of the final site condition at the Lowman disposal site is found in the Lowman permanent site file as indicated in Attachment 3. This record consists of a series of aerial and ground photographs that provide a baseline visual record of final site construction activities and final site conditions to complement the as-built drawings. The post-construction photographs provide an orientation tool prior to site inspection and provide a baseline record of surveillance features. The final completion report for the disposal site contains two sets of baseline photographs. One set was taken during the remedial action to illustrate implementation of the final design and site construction methods. These photographs may provide useful construction details in the event that repairs or corrective action become necessary. A second set of photographs was taken at the end of construction to document as-built conditions.

\subsection{SITE AERIAL PHOTOGRAPHS}

Aerial photographs for the Lowman disposal site were taken in June 1992, after the completion of surface remedial action. These photographs provide a permanent record of site conditions, enable inspectors to monitor changes in site conditions (e.g., erosion patterns, vegetation changes, land use) over time, and provide a useful orientation tool prior to inspections of the disposal site. The need for new aerial photographs will be evaluated at 5 -year intervals, beginning with the year the license becomes effective for the Lowman site. A summary of the specifications for aerial photographs at the Lowman disposal site is provided in Table 3.1, while more detailed guidance is provided in Attachment 3 of the Guidance for Implementing the UMTRA Project Long-term Surveillance Program (DOE, 1992).

\subsection{SITE INSPECTION PHOTOGRAPHS}

Photographs will be taken during site inspections to document conditions of the disposal cell and the disposal site to provide a continuous record for monitoring changing conditions over time. These photographs can be compared with the baseline photographs to determine if the integrity of the site has been affected.

Each photograph will be recorded individually on the photo log form (Attachment 4). An appropriate description of the feature photographed, including the azimuth (if necessary), will be entered on the log form. Copies of the photographs and the photo logs will be included in annual site inspection reports.

Whenever possible, a photograph should include a reference point such as a survey monument, boundary monument, site marker, or monitor well. For large-scale features such as drainage ditches or disposal cell slopes, a north arrow and scale will be included for reference. 
Table 3.1 Aerial photography specifications for the Lowman disposal site

\section{AREA TO BE PHOTOGRAPHED}

- Final disposal site plus a minimum of $0.25 \mathrm{mi}(0.4 \mathrm{~km})$ beyond site boundaries unless site conditions require otherwise.

\section{PRODUCTS TO BE DELIVERED}

- One set of vertical color, infrared stereo contact prints, 9-inch (in) 123-centimeter (cm)l, scale 1 in $=200 \mathrm{ft}(1 \mathrm{~cm}=24 \mathrm{~m})$ (representation fraction 1:2400); double weight, glossy, not trimmed.

- One index map, scale $1 \mathrm{in}=200 \mathrm{ft}(1 \mathrm{~cm}=24 \mathrm{~m})$; flight lines and frame numbers will be provided.

- One set of 2 each of low and high oblique photographs (and negatives) in natural color, 8-in by $10-$ in $(20-\mathrm{cm}$ by $25-\mathrm{cm})$; or $9-$ in by $9-\mathrm{in}(23-\mathrm{cm}$ by $23-\mathrm{cm})$ contact prints.

\section{FLIGHT DATE}

- To be determined upon the acceptance of this LTSP.

\section{CAMERA}

- Precision, 9-in by 9 -in $(23-\mathrm{cm}$ by $23-\mathrm{cm})$ format for vertical photos. A 35 -millimeter (single lens reflex) or larger format camera for oblique photos is acceptable.

\section{FILM}

- Eastman-Kodak Aerochrome Infrared 2443, or its equivalent, for vertical photos.

- Eastman-Kodak Ektacolor, or its equivalent, for oblique photos.

\section{FILTER}

- Wratten Nos. 12 or 15 for infrared photos. Skylight filter for color photos.

\section{FLIGHT LINE COVERAGE}

- Sixty percent end overlap; 30 percent average side overlap.

\section{GROUND CONTROL}

- Control stations will be second order, Class 1, for horizontal control and third order for vertical control |Standard U.S. Geological Survey map accuracy specifications/. 
For specific areas where the photograph is used to monitor change over time, the distance from the feature and the azimuth will be recorded, and all subsequent photographs will be taken from the same orientation to provide a more accurate picture of changing conditions. The magnetic declination of the compass should be corrected for true north. This information will also be provided on the site inspection checklist and photo log.

All site inspection photographs taken, as well as all corresponding photo log forms, will be maintained in the permanent Lowman site file.

\subsubsection{Features to be photographed}

The following disposal site features should be documented with photographs during every scheduled inspection at the Lowman site:

- Permanent site surveillance features.

- Access gate and access road.

- Drainage gully and drainage channels.

- Perennial spring located outside southwest corner of disposal site boundary.

- Groundwater monitor wells.

- Radioactive sands embankment.

- Disposal cell (top, sides, apron, and surrounding area). Panoramic staquences of photographs from selected vantage points may be used for this purpose.

- Area around the site for signs of erosion, development, or other disturbances that may affect the site.

- Large mulched area north of the site.

- Mulched area west of the site.

- Seeps and spring west of the radioactive sands embankment.

- Erosion protection material (riprap).

- Potential erosion in steeper areas adjacent to the radioactive sands embankment. 
Any new or potential problem areas identified during a site inspection will be well documented with photographs. Photographs will also be taken to provide a record of developing trends and to allow inspectors to make reasonable decisions concerning additional inspections, custodial maintenance or repairs, or corrective actions. 


\subsection{PERMANENT SITE SURVEILLANCE FEATURES}

Survey and boundary monuments, site markers, and entrance and perimeter signs are the permanent surveillance features at the Lowman disposal site. Three survey/boundary monuments and four boundary monuments define the seven corners of the irregularly shaped and unfenced perimeter of the disposal site. Twenty perimeter (warning) signs (including two along the south entrance) were placed at spaced intervals around the disposal site so that one or more signs will be visible in daylight to a person approaching from any direction. One of the perimeter signs and one site marker were placed at the official entrance to the disposal site at the southwest corner. The other site marker was placed near the center of the disposal cell on the 10:1 topslope.

The construction and emplacement of the site surveillance features are described below and are in accordance with the specifications set forth in the DOE's Guidance for Implementing the UMTRA Project Long-term Surveillance Program (DOE, 1992). The coordinates for the boundary and survey monumen:s and site markers are presented in Table 4.1.

\subsection{SURVEY MONUMENTS}

Three survey monuments, Berntsen RT-1 metal markers, were set into the top of a truncated cone of reinforced concrete that is set in concrete. The design of the survey/boundary monuments is shown in Figure 4.1. The depths of the holes for the survey/boundary monuments were chosen so that the bottom of the holes were at least 18 in $(46 \mathrm{~cm})$ below frost line [total depth 38 in $(97 \mathrm{~cm})$ ). The four metal bars in each hole used as reinforcement for the concrete also serve the additional purpose of being potential locating devices when using metal detectors should any of the monuments become buried over time. The monument extends at least 4 in $(10 \mathrm{~cm})$ above the ground surface for easy location.

\subsection{BOUNDARY MONUMENTS}

Berntsen Federal aluminum survey monuments, Model A-1, were used for the four site boundary monuments. The design of the boundary monument is shown in Figure 4.2. The ceramic magnets epoxied in the cap and base are vertically oriented for maximum detection if they become covered. The monuments were set with the base 38 inches (in) 197 centimeters $(\mathrm{cm}) /$ below the ground surface and the top 10 in $(25 \mathrm{~cm})$ aboveground to facilitate location.

\subsection{SITE MARKERS}

Two unpolished grarite site markers constructed with the dimensions shown in Figure 4.3 identify the Lowman disposal site; the general location of the disposal cell; the date of closure, September 14, 1991; the dry tonnage of residual 
Table 4.1 Locations of monuments and markers

\begin{tabular}{|c|c|c|}
\hline Symbol & Elevation & Coordinates" \\
\hline \multicolumn{3}{|c|}{ Site boundary corners } \\
\hline 1 & & $\frac{N 10,550.00}{E 10,700.00}$ \\
\hline 2 & & $\frac{N 11,220.00}{E 10,890.00}$ \\
\hline 3 & & $\frac{N 11,240.00}{E 11.730 .00}$ \\
\hline 4 & & $\frac{N}{E} 10, \frac{500.00}{11,520.00}$ \\
\hline 5 & & $\frac{N 10,285.00}{E 11.220 .00}$ \\
\hline 6 & & $\frac{N 10,210.00}{E 10,980.00}$ \\
\hline 7 & & $\frac{N 10,170.00}{E 10.705 .00}$ \\
\hline \multicolumn{3}{|c|}{ Survey/boundary monuments $^{b}$} \\
\hline$S M-1 / B M T-1$ & 3899.034 & $\frac{N 10,539.96292}{E 10.710 .06382}$ \\
\hline SM-2/BMT-2 & 3933.126 & $\frac{N 11.209 .92412}{E 10.900 .05850}$ \\
\hline SM-4/BMT-4 & 4119.645 & $\frac{N 10,510.00201}{E 11,509.99253}$ \\
\hline \multicolumn{3}{|c|}{ Boundary monuments } \\
\hline BMT-3 & 4205.829 & $\frac{N 11,229.94570}{E 11,720.01856}$ \\
\hline BMT-5 & 4009.436 & $\frac{N 10,294.94351}{E 11,210.00108}$ \\
\hline BMT-6 & & $\frac{N 10,220.00}{E 10,970.00}$ \\
\hline BMT-7 & & $\frac{N 10,180.00}{E 10,715.00}$ \\
\hline \multicolumn{3}{|l|}{ Site markers } \\
\hline SMK 1 & & $\frac{N 10,330.00}{E 10,720.00}$ \\
\hline SMK 2 & & $\frac{N 10,780.00}{E 11,160.00}$ \\
\hline
\end{tabular}

${ }^{a}$ The coordinates are based on the project survey control points established by the BLM.

${ }^{b}$ Actual coordinates and elevations surveyed after installation of monuments and markers. 


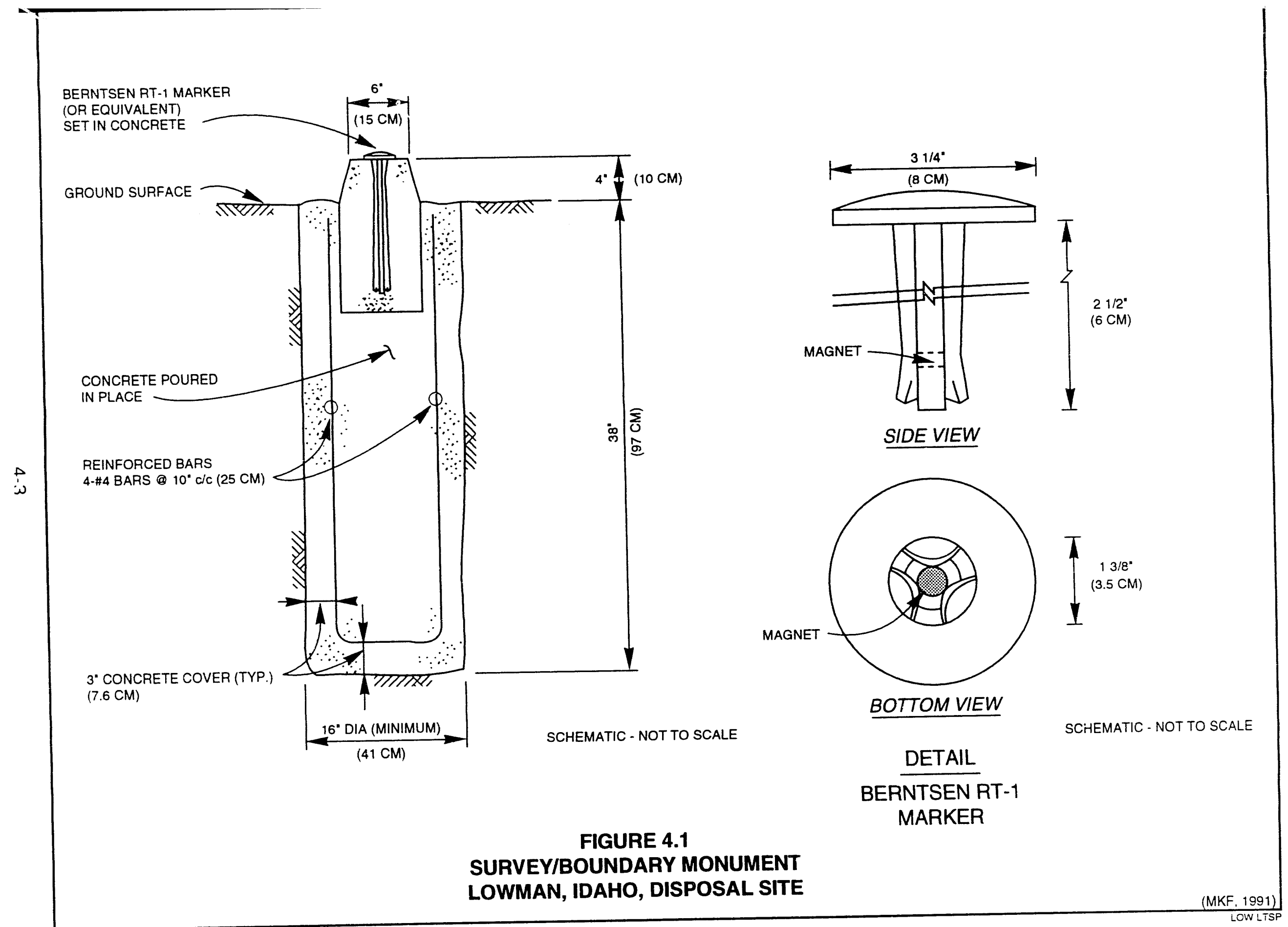




\section{BERNTSEN FEDERAL ALUMINUM SURVEY MONUMENT, MODEL A-1, STANDARD LOGO CAP}

$\stackrel{p}{a}$
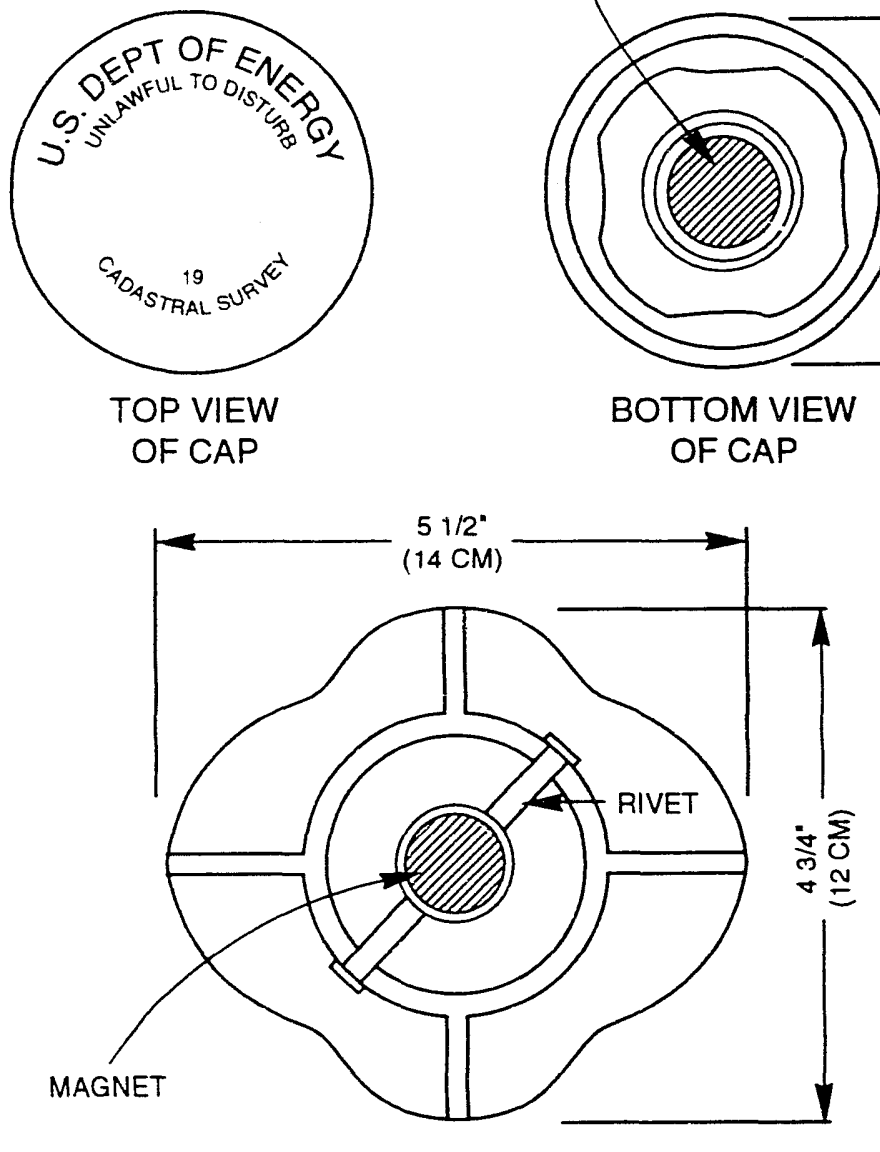

TOP VIEW OF BASE

BOTTOM VIEW

OF CAP

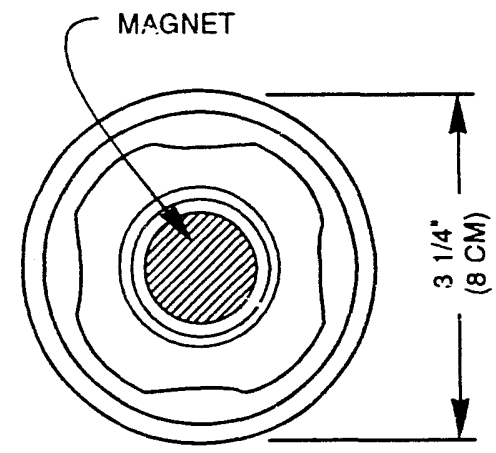

FIGURE 4.2

BOUNDARY MONUMENT

LOWMAN, IDAHO, DISPOSAL STTE

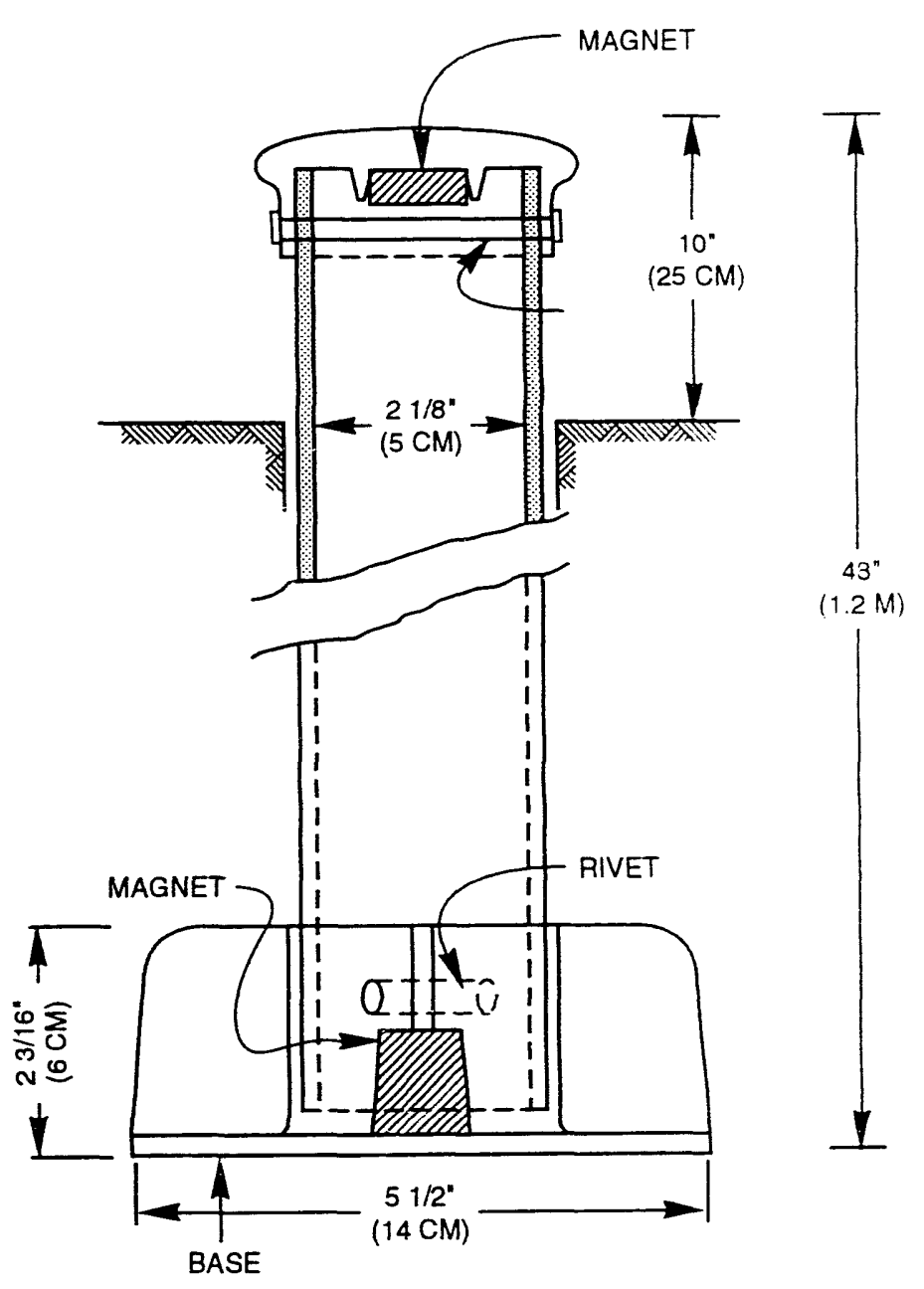




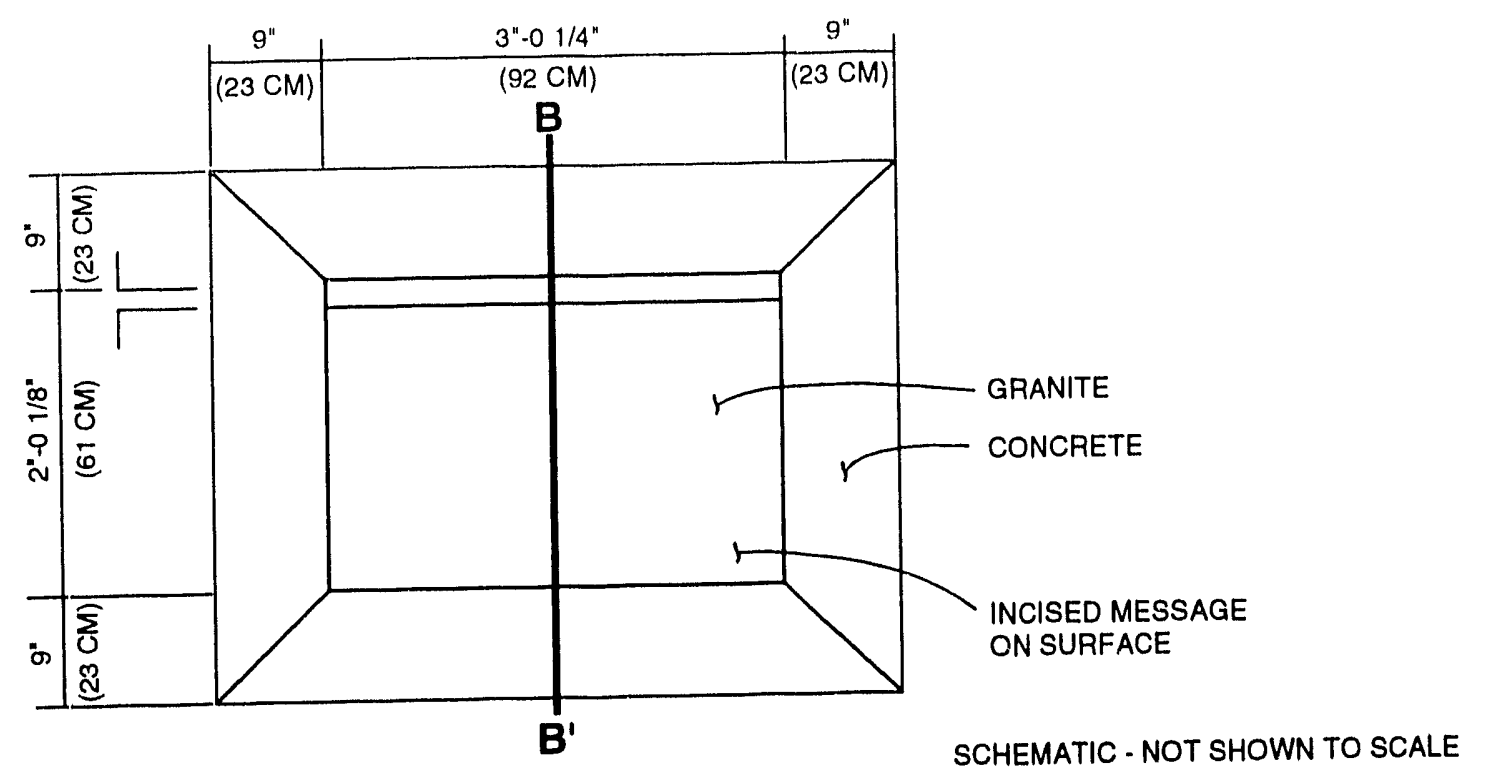

PLAN VIEW OF SITE MARKER

(SEE CROSS SECTION B - B' IN FIGURE 4.4)

\section{LOWMAN, IDAHO}

\section{DATE OF CLOSURE: DRY TONS OF TAILINGS: RADIOACTIVITY: \\ SEPTEMBER 14, 1991 222, 230 12 CURIES, RA-226}

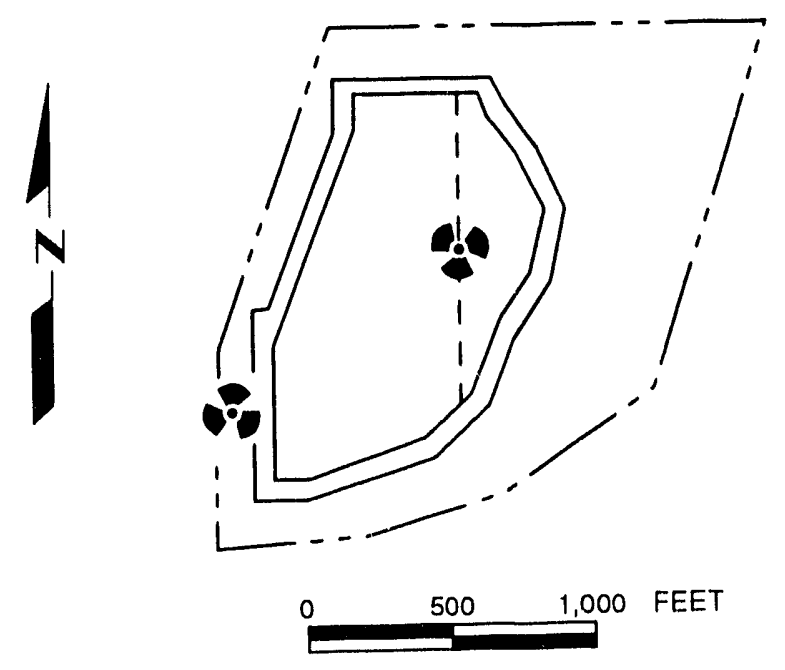

INCISED MESSAGE

NOTE: MINIMUM DEPTH OF

INCISING TO BE 1/4" (0.6 CM)
FIGURE 4.3

SITE MARKER INCISED MESSAGE LOWMAN, IDAHO, DISPOSAL SITE 
radioactive materials $(222,230)$, and the curies of radioactivity $(12$ curies, Ra-226). Site marker SMK 1, near the entrance to the site, is set in a bed of reinforced concrete that extends $3 \mathrm{ft}(0.9 \mathrm{~m})$ below ground surface (Figure 4.4). Site marker SMK 2, at the center of the cell, is set in a bed of reinforced concrete that extends to the top of the infiltration radon barrier (Figure 4.4). The excavation and setting of SMK 2 was conducted in such a manner so as to keep disturbance of the surrounding riprap and underlying material to a minimum.

\subsection{ENTRANCE AND PERIMETER SIGNS}

Twenty perimeter warning signs mounted on steel posts were placed at approximately $200-\mathrm{ft}(61-\mathrm{m})$ intervals. These signs display the international symbol indicating the presence of radioactive materials. They also state that the disposal site is Government property, that it contains residual radioactive materials, and that trespassing is forbidden (Figure 4.5). The two entrance signs have the same information as the perimeter signs plus the name of the site and the name and telephone number of the DOE Grand Junction Projects Office (Figure 4.6).

Whenever the DOE telephone number changes, the signs must be corrected and replaced.

The signs are constructed in accordance with the dimensions and specifications shown in Figures 4.5 and 4.6. The tops of the signs are 70 in $(180 \mathrm{~cm})$ above the ground surface; the sign posts are embedded in concrete to a depth of 38 in $(97 \mathrm{~cm})$ below ground surface.

\subsection{SETTLEMENT PLATES}

Long-term settlement of the disposal cell will be very small, because the materials were compacted during placement. Settlement of the bedrock foundation will be negligible. Therefore, the potential hazards of settlement, including differential settlement-induced cracking of the radon barrier, were considered acceptably small; and settlement plates were not required. 

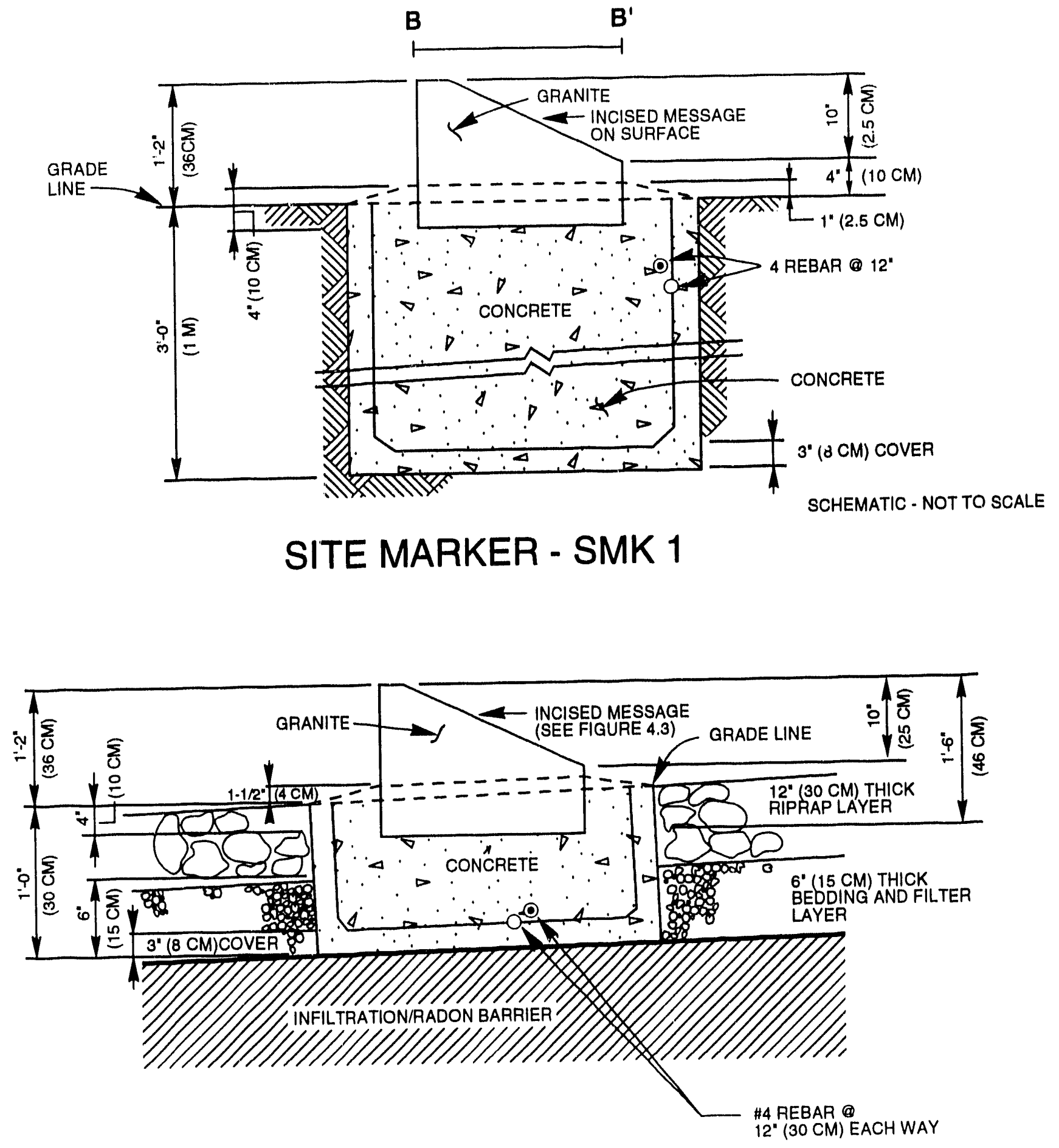

SCHEMATIC - NOT TO SCALE

\section{SITE MARKER - SMK 2 SIDE VIEWS}

FIGURE 4.4

SITE MARKER SPECIFICATIONS

LOWMAN, IDAHO, DISPOSAL 


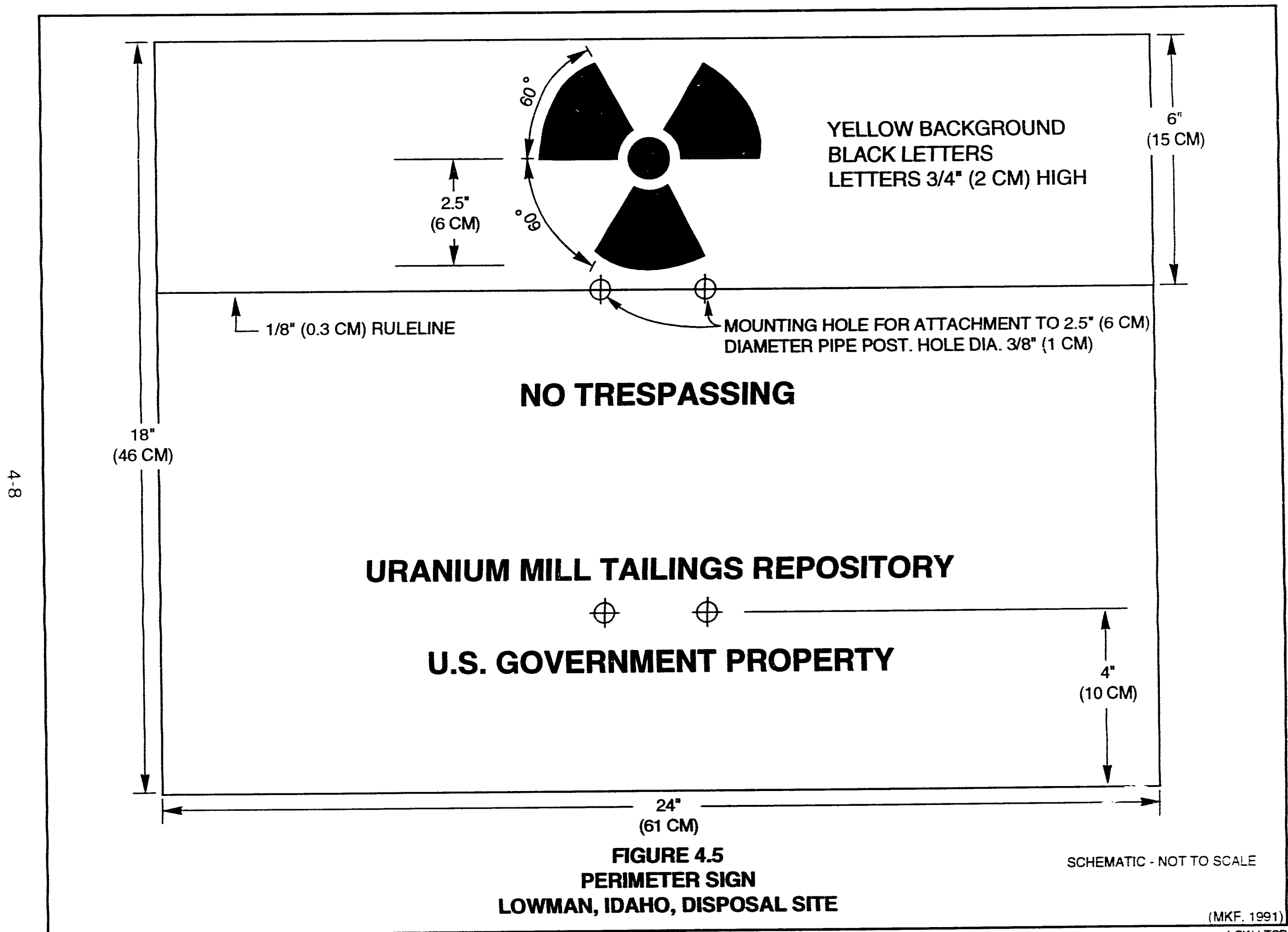




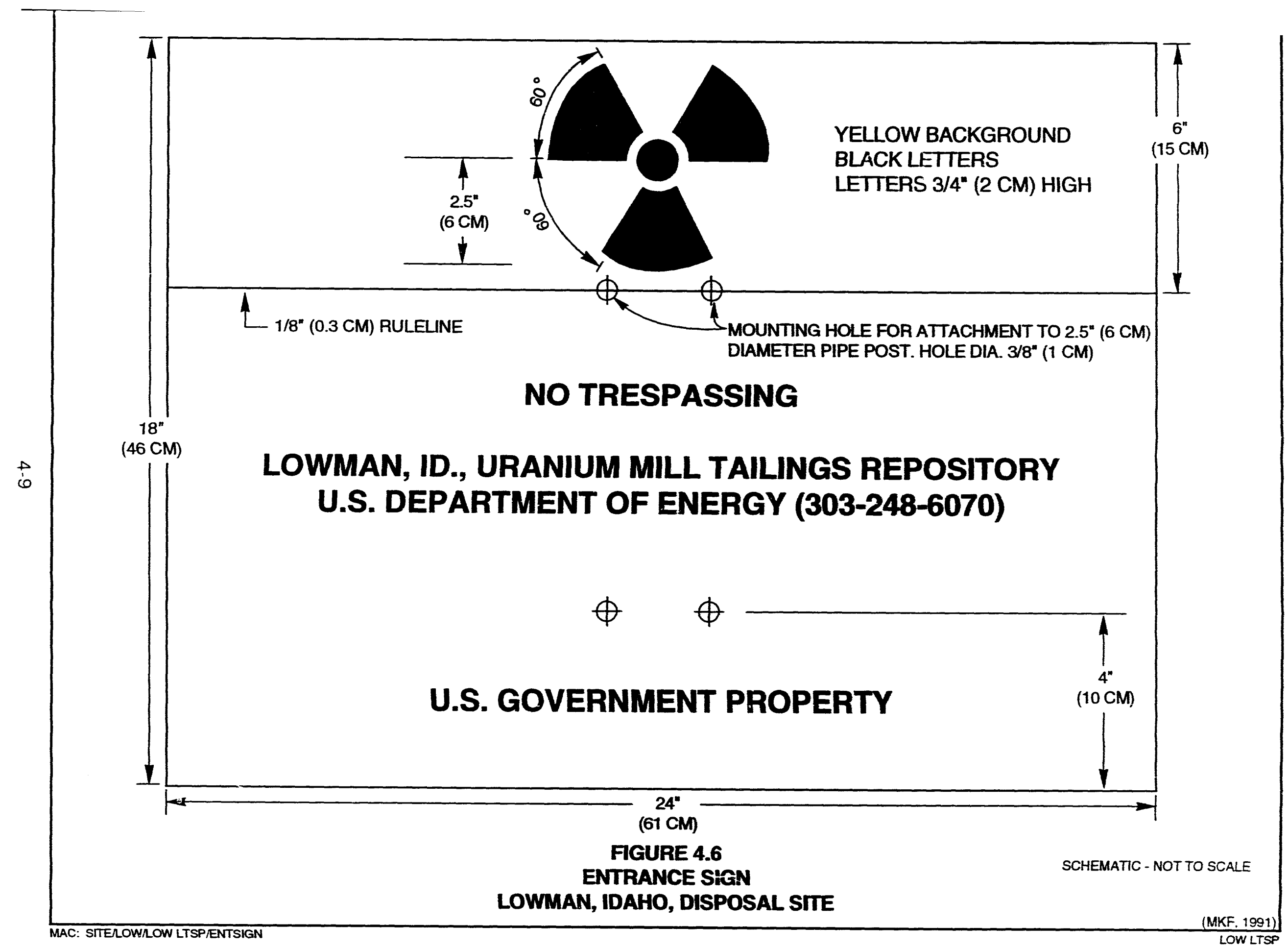




\subsection{GROUNDWATER MONITORING}

NRC regulations in 10 CFR 40.27 (b) require that the disposal site LTSP describe existing groundwater conditions and any groundwater activities or strategies that may be required at the disposal site to comply with the proposed EPA stanclards (52 FR 36000) issued in 1987. The existing design of the disposal site should be sufficient to provide long-term protection against future groundwater contamination at the Lowman site. The DOE will comply with the published proposed groundwater quality standards until the final standards are in effect. When the proposed standards become final, the DOE will reevaluate the monitoring program for compliance with the final standard.

The radioactive sands at the Lowman site were stabilized on the site. The DOE has demonstrated in the RAP that the Lowman disposal site will comply with Subpart A 140 CFR 192) of the proposed EPA groundwater protection standards by constructing a disposal cell that will prevent any radioactive sand leachate from mixing with groundwater within the required 1000-year design life of the cell, or at a minimum of 200 years (DOE, $1991 \mathrm{bl}$. Specifically, either designated maximum concentration limits $(M C L)$ or background water quality concentrations (whichever are greater) will not be exceeded in the uppermost aquifer at the point of compliance (POC).

A groundwater monitoring program is necessary for the UMTRA Lowman disposal site, based on the criteria for establishing a groundwater monitoring program set forth in 40 CFR 192.02 (a)-(c). The groundwetisr monitoring program will be implemented and conducted over a specified period of time adequate to demonstrate that the initial performance of the disposal cell is in accordance with the design requirements. The DOE is also responsible for demonstrating that any required cleanup or control of existing processing-related groundwater contamination at the Lowman processing site complies with the proposed EPA groundwater protection standards in Subparts $A$ through $C$ of 40 CFR 192. Given the conditions at the Lowman site, no existing process-related groundwater contamination exists and no cleanup or control will be required.

Long-term surveillance groundwater monitoring at the disposal site involves 11 the performance assessment developed in conjunction with the disposal cell design; 2) the identification of specific hazardous constituents to be monitored, as necessary; and 3) the establishment of conceritration limits for the monitored constituents (DOE, 1992). Details of the site characterization are provided in the Lowman RAP (DOE, 1991b) and the EA (DOE, 1991a).

\subsection{GROUNDWATER CHARACTERIZATION}

The DOE has characterized the hydrogeologic units, aquifer hydraulic and transport properties, radioactive sand materials, and geochemical conditions at the Lowman disposal site. This information is summarized in the following subsections.

The DOE has demonstrated in the RAP that the Lowman disposal site will comply with Subpart A (40 CFR 192) of the proposed EPA groundwater protection 
standards by meeting MCLs for designated hazardous constituents in the underlying uppermost acpuifer at the POC. Complance with the groundwater standards will be achieved for the following reasons:

- The disposal option prepared for the Lowman site involved consolidation of radioactive sands and associated contaminated materials at the site. The materials were placed in an above-grade disposal cell designed to reduce radon emanation, resist erosion, preclude differential settlement, and remain stable against static and dynamic forces.

- Design features in conjunction with existing conditions at the Lowman disposal site will achieve compliance with the proposed EPA groundwater protection standards at the Lowman disposal site. The DOE proposed to meet MCLs or background concentrations for the designated hazardous constituents in groundwater at the POC in the uppermost aquifer hydraulically downgradient from the disposal unit. The alluvium/weathered granodiorite is the uppermost aquifer at the Lowman disposal site. Compliance with EPA standards will ensure protection of human health and the environment.

- The selection of hazardous constituents to be monitored was based on hydrogeologic characterization at the Lowman site. Hazardous constituents resulting from the uranium processing operations suspected to be present in materials stabilized at the Lowman disposal site were investigated. The hazardous constituents were identified from descriptions of the uranium recovery process, characterization of the contaminated materials, and evaluation of groundwater quality data. Based on chemical analyses of pore fluids from suction lysimeters placed at or near the base of the radioactive sands, several hazardous constituents exceeded laboratory method detection limits. They included antimony, barium, molybdenum, net gross alpha, nitrate, and uranium. Chromium, lead, and radium-226 and -228 also exceeded the laboratory method detection limits in neutral pH batch-leach tests. However, no mean concentrations of hazardous constituents exceeded the MCLs, and only pore fluid concentrations of antimony in radioactive sands exceed the statistical maximum for background groundwater quality. Antimony was designated as a hazardous constituent with a sufficiently high source concentration to potentially affect groundwater quality.

- The DOE has assessed the performance of the proposed disposal cell at the Lowman site in conjunction with the area's hydrogeologic system. This assessment has shown that the disposal cell will minimize and control releases of the hazardous constituents to groundwater and surface water and radon emanations to the atmosphere to the extent necessary to protect human health and the environment. Natural, stable materials were used in construction of the Lowman disposal cell to ensure long-term performance. The DOE has also demonstrated that design features necessary for compliance with the EPA groundwater protection standards minimize the need for further maintenance of the disposal site (DOE, 1991b). 


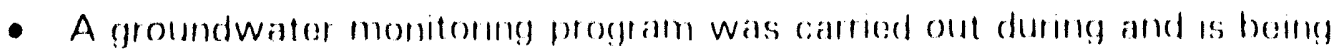
condesed atter the remedial action period to demonstrate that the mithal performance of the disposal coll is in accordance with the design requirements and to ensure compliance of the disposial site with the EPA groundwater protection standards. Groundwater in the uppermost aquifer will be monitored upgradient and downgradient from the disposal cell at the POC. Downgradient water will be monitored using the four POC wells and a spring. Background water quality will be monitored using two existing upgradient wells. Compliance wells will be sampled annually in 1994 and 1995. Monitoring data will be reviewed and analyzed, and recommendations will be presentc t in the Lowman water sampling analysis plan (WSAP). The constituents to be monitored will include the designated hazardous constituent and a standard suite of indicator parameters (Table 5.1).

Table 5.1 List of monitored constituents and their statistical maximum background groundwater concentrations

\begin{tabular}{lc}
\hline \multicolumn{1}{c}{ Monitored constituent } & $\begin{array}{c}\text { Maximum concentrations in } \\
\text { background } \text { (mg/L) }\end{array}$ \\
\hline Antimony & 0.007 \\
Major ions (indicator parameters) & 56 \\
Calcium & 9.6 \\
Chloride & 0.08 \\
Iron & 8.77 \\
Magnesium & 0.48 \\
Manganose & 11.82 \\
DH & 3.68 \\
Potassium & 57 \\
Sodium & 80 \\
Sultate & 280 \\
TDS & 280 \\
\hline
\end{tabular}

"Monitor wolls 576, 578, 579, 583, 585, and 641 were used to dotermine buckeround groundwator quality based on data colloctod botwoon August 1987 and April 1993.

- Site characterization suggests that no preexisting contamination of groundwater is present and that groundwater cleanup will not be required. Therefore, demonstration of cleanup and control of existing processing-related groundwater contamination will not be necessary. 


\subsubsection{Hydrostratigraphy}

The Lowman site lies on a shallow terrace above Clear Creek, approximately $0.25 \mathrm{mi}(0.4 \mathrm{~km})$ upstream from the confluence with the south fork of the Payette River. The moderately sloping terrace consists of colluvium, alluvium, and glacial outwash deposits underlain by granodiorite bedrock. Glacial outwash deposits form an upper alluvial terrace lying approximately $80 \mathrm{ft}(24 \mathrm{~m})$ above Clear Creek at the Lowman site. The bottom of this terrace consists of 10 to $50 \mathrm{ft}(3$ to $15 \mathrm{~m})$ of gravel and cobbles in a sandy matrix, grading upward to finer-grained alluvium and sandy, clayey colluvium. A lower fluvial terrace lies approximately $25 \mathrm{ft}(8 \mathrm{~m})$ above Clear Creek and is comprised of silty, clayey sand and sandy gravels with lenses of cobbles and boulders. Underlying these unconsolidated deposits is a granodiorite bedrock that is moderately to highly weathered and is densely fractured. A geologic cross section is shown in Figure 5.1.

Groundwater beneath the Lowman site occurs in alluvium/weathered granodiorite and the fractured zone of the deeper nonweathered granodiorite. The uppermost aquifer at the Lowman site is the alluvium/weathered granodiorite. No deep regional aquifers underlie the site. Depth to groundwater beneath the site ranges from 27 to $78 \mathrm{ft}(8$ to $24 \mathrm{~m})$ in the upper glacial outwash terrace to $6 \mathrm{ft}(2 \mathrm{~m})$ in the lower fluvial terrace adjacent to Clear Creek. A potentiometric map of the alluvium/weathered granodiorite is shown in Figure 5.2.

Groundwater beneath the site is recharged from rainfall and snowmelt. The groundwater at the site flows west by southwest, along the alluvium/granodiorite bedrock contact and within a preferential flow path created by a paleochannel. Groundwater at the site discharges to an on-site perennial spring (monitoring site \#561) and into Clear Creek (Figure 5.3).

Hydraulic conductivities were measured in the granodiorite bedrock using sluginjection tests. The average hydraulic conductivity of the nonweathered granodiorite is $0.02 \mathrm{ft}$ per day $(\mathrm{ft} / \mathrm{day})\left(7.1 \times 10^{-6} \mathrm{~cm} / \mathrm{sec}\right)$. An average linear groundwater velocity in the alluvium/weathered granodiorite of $0.15 \mathrm{ft} / \mathrm{day} / 5.3 \times$ $10^{-5} \mathrm{~cm} / \mathrm{sec}$ ) was calculated using an average hydraulic gradient of 0.07 and an effective porosity of 25 percent. Additional information is provided in Attachment 3 of the Lowman RAP (DOE, 1991b).

\subsubsection{Background ground water quality}

Background groundwater quality is defined as the groundwater quality from a hydrogeologic unit at the disposal site that has not been contaminated by uranium processing activities ITechnical Approach Document (TADII (DOE, 1989). Background groundwater quality at the Lowman site was characterized by a monitor well network as noted in Attachment 3 of the RAP (DOE, 1991b). The statistical maximum concentration of hazardous constituents was used as a basis for developing concentration limits in the water resources protection strategy presented in Attachment 4 of the RAP (DOE, 1991b). None of the hazardous 


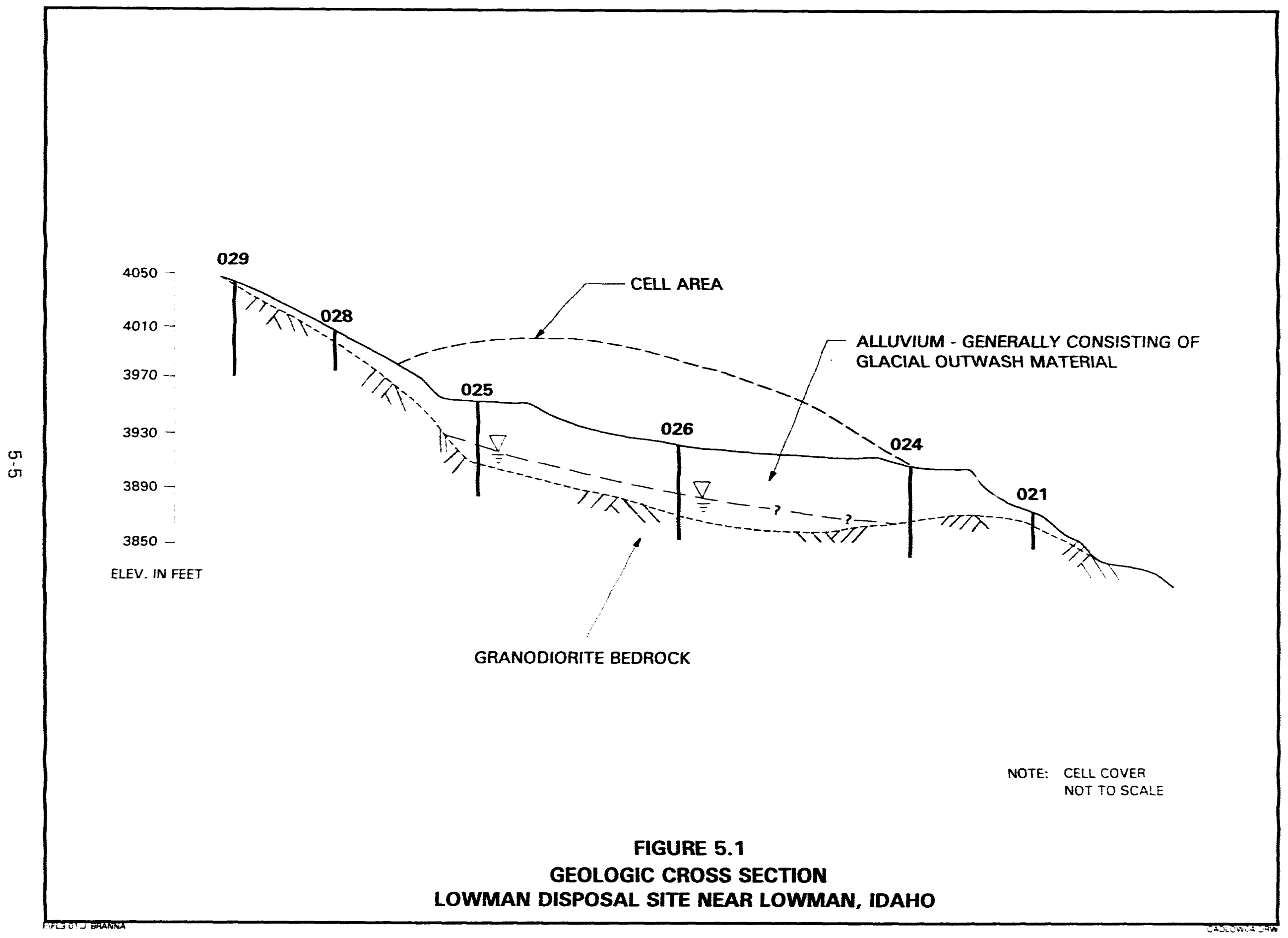




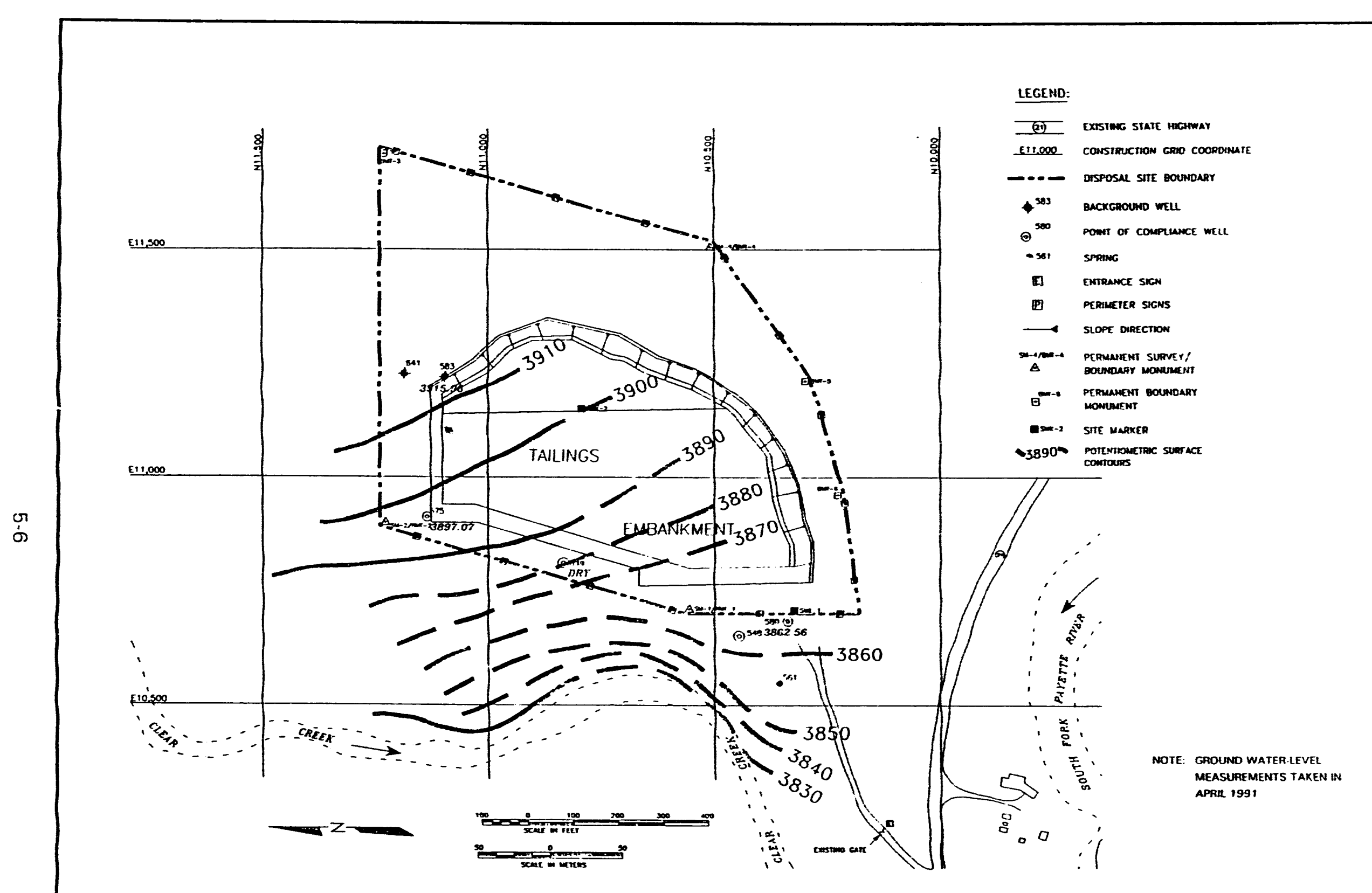

FIGURE 5.2

POTENTIOMETRIC MAP OF ALLUVIUM/WEATHERED GRANODIORITE, APRIL 1991 


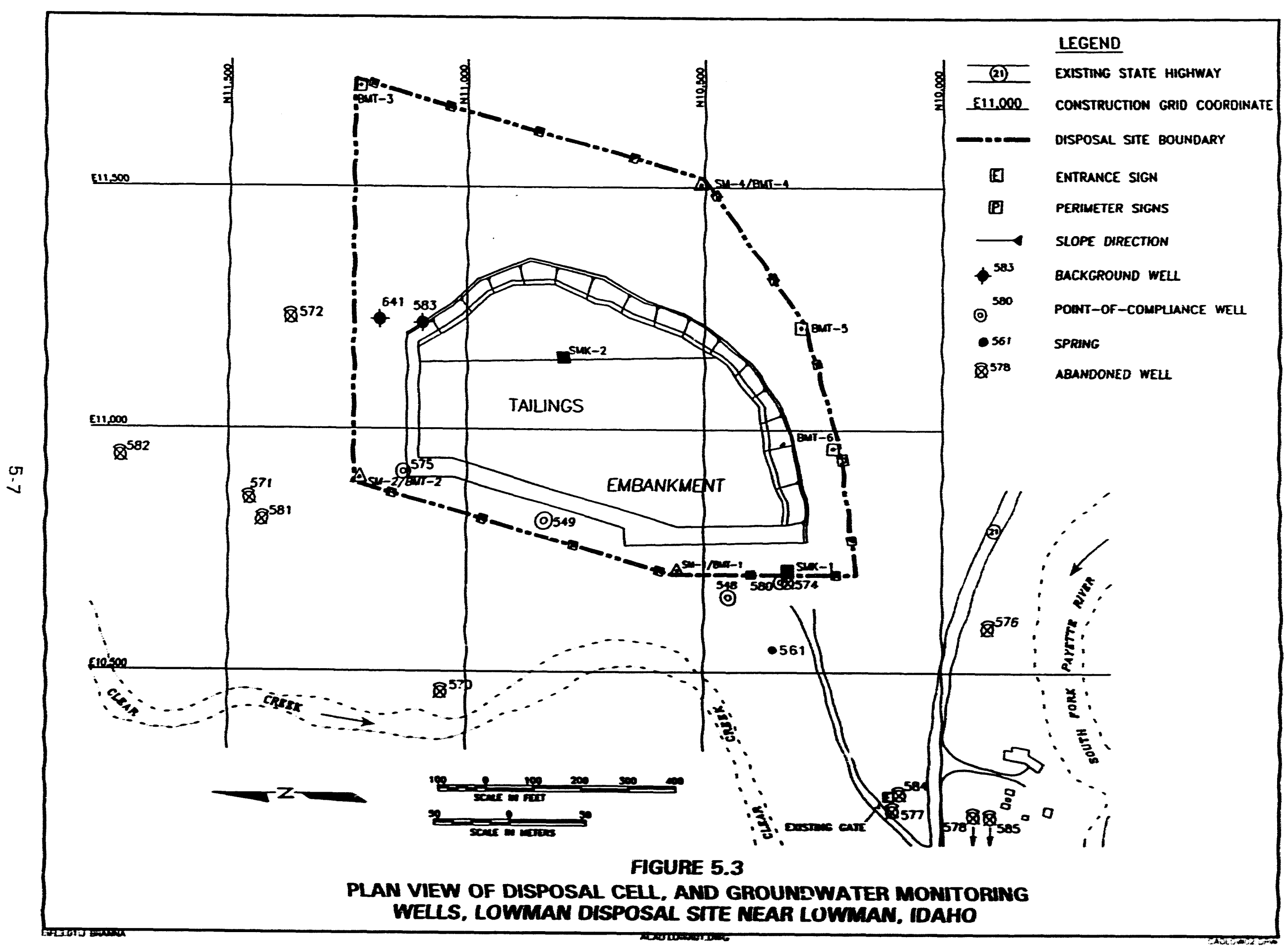


constituents in background water exceed EPA MCLs. A statistical summary of the background groundwater quality is provided in Table 5.2 .

\subsubsection{Monitored constituents and concentration limits}

The proposed EPA groundwater protection standards consist of three components: 1) a list of the designated hazardous constituents from Table 1, Appendix 1, to 40 CFR 192, and Appendix IX to 40 CFR 264; 2) a corresponding list of proposed concentration limits for the constituents; and 3 ) a POC.

The DOE proposes to achieve compliance with the proposed EPA groundwater protection standards (Subparts $A$ and $B$ of 40 CFR 192) by meeting the EPA MCLs or background concentrations for antimony, the designated hazardous constituent in groundwater in the uppermost aquif? (alluvium/weathered granodiorite) at the POC at the Lowman disposal site. The DOE has concluded that the EPA groundwater protection standards will be met at the POC because, with the exception of antimony, none of the hazardous constituents that exceed laboratory method detection limits within the radioactive sand pore fluids were above the proposed concentration limits. The DOE has demonstrated that antimony will meet the proposed concentration limits at the POC through attenuation in subsoils beneath the disposal cell and by dilution in groundwater underflow. The Lowman processing site is in compliance with the groundwater portion of Subpart B of 40 CFR 192, because statistical analyses of groundwater samples indicate no groundwater contamination. To support these arguments further, a detailed discussion is presented in Attachment 3 of the RAP (DOE, 1991b). The list of monitored constituents and their maximum background concentrations are presented in Table 5.1.

Although site characterization activities used six monitor wells to determine background groundwater quality, only two background monitor wells (641 and 583) will be monitored during the post-remedial action surveillance. These two monitor wells are located upgradient of the disposal cell and are completed in the uppermost aquifer (alluvium/weathered granodiorite).

\subsubsection{Baseline groundwater quality}

Baseline water quality for the disposal sites is defined as the representative water quality of groundwater that has been potentially influenced by uranium processing activities at a disposal site where the residual radioactive materials were stabilized. Baseline water quality has been characterized at the Lowman site with monitor wells 570,571,575,580,581, and an on-site perennial spring (monitor station 5611 . Statistical analysis indicates that no evidence of preexisting contamination is present as a result of radioactive sands at the site IAttachment 3 of the RAP IDOE, 1991bll. Monitor wells 570, 571, and 581 were abandoned in August 1992. 
Table 5.2 Statistical summary of background groundwater quality

\begin{tabular}{lcccc}
\hline \multicolumn{1}{c}{ Constituent } & $\begin{array}{c}\text { Number of } \\
\text { samples }\end{array}$ & $\begin{array}{c}\text { Minimum } \\
\text { (mg/L) }\end{array}$ & $\begin{array}{c}\text { Maximum } \\
\text { (mg/L) }\end{array}$ & $\begin{array}{c}\text { Mean or media } \\
\text { (mg/L) }\end{array}$ \\
\hline Maior ions & & & & \\
Calcium & 41 & 7.7 & 56 & $40^{\text {a }}$ \\
Chloride & 41 & 0.5 & 9.6 & 1.0 \\
lron & 34 & 0.03 & 0.08 & 0.03 \\
Magnesium & 41 & 0.37 & 8.77 & $4.39^{\text {a }}$ \\
Manganese & 39 & 0.01 & 0.48 & 0.01 \\
pH & 45 & 5.27 & 11.82 & 7.42 \\
Potassium & 41 & 0.90 & 3.68 & $1.65^{\mathrm{a}}$ \\
Sodium & 41 & 5.28 & 57 & $15^{\mathrm{a}}$ \\
Sulfate & 40 & 0.1 & 80 & $8.5^{\mathrm{a}}$ \\
TDS & 41 & 65 & 280 & $177^{\mathrm{a}}$
\end{tabular}

EPA inorganics with MCLs

$\begin{array}{lllll}\text { Arsenic } & 41 & 0.01 & 0.01 & 0.01^{\mathrm{b}} \\ \text { Barium } & 45 & 0.01 & 0.70 & 0.24^{\mathrm{a}} \\ \text { Cadmium } & 41 & 0.0005 & 0.0025 & 0.0005 \\ \text { Chromium } & 45 & 0.01 & 0.04 & 0.01 \\ \text { Lead } & 45 & 0.003 & 0.04 & 0.005 \\ \text { Mercury } & 26 & 0.0002 & 0.0002 & 0.0002^{\mathrm{b}} \\ \text { Molybdenum } & 44 & 0.01 & 0.02 & 0.01 \\ \text { Nitrate (as NO } & 45 \text { ) } & 1 & 24 & 3 \\ \text { Selenium } & 45 & 0.005 & 0.005 & 0.005^{\mathrm{b}} \\ \text { Silver } & 33 & 0.01 & 0.01 & 0.01^{\mathrm{b}} \\ \text { Ra-226 and -228 (pCi/L) } & 31 & 0.1 & 7.4 & 0.7^{\mathrm{a}} \\ \text { U-234 and -238 } & 40 & 0.0005 & 0.0109 & 0.0019 \\ \text { Net gross alpha (pCi/L) } & 45 & -1.2 & 8.3 & 0.3\end{array}$

Other Appendix IX constituents (40 CFR 264)

\begin{tabular}{lllll} 
Antimony & 45 & 0.003 & 0.007 & 0.003 \\
Beryllium & 21 & 0.005 & 0.005 & $0.005^{\mathrm{b}}$ \\
Cobalt & 22 & 0.03 & 0.03 & $0.03^{\mathrm{b}}$ \\
Copper & 27 & 0.01 & 0.01 & $0.01^{\mathrm{b}}$ \\
Cyanide & 36 & 0.01 & 0.01 & $0.01^{\mathrm{b}}$ \\
Nickel & 29 & 0.04 & 0.04 & $0.04^{\mathrm{b}}$ \\
Sulfide & 23 & 0.1 & 4.7 & $0.4^{1}$ \\
Thallium & 21 & 0.01 & 0.05 & 0.01 \\
Tin & 19 & 0.005 & 0.005 & $0.005^{\mathrm{b}}$ \\
Vanadium & 41 & 0.01 & 0.03 & 0.01 \\
Zinc & 41 & 0.005 & 0.09 & 0.007 \\
\hline
\end{tabular}

aMean value

"These statistical values result from values being reported at or below analytical detection limit. Monitor wells 576, 578,579,583,585, and 641 were used to determine background groundwater quality. Samples were collected between August 1987 and April 1993.

$\mathrm{mg} / \mathrm{L}=$ milligrams per liter

TDS $=$ total dissolved solids

$p \mathrm{Ci} / \mathrm{L}=$ picocuries per liter 
Baseline groundwater quality will be monitored at the POC at the Lowman site using monitor wells 548, 549,575, and 580 and the perennial spring (monitor station 561) located downgradient of the disposal cell. The locations of the POC wells are illustrated in Figure 5.3. Background groundwater will be monitored, using monitor wells 641 and 583, to indicate changes in local groundwater quality (Figure 5.3).

\subsection{GROUNDWATER MONITORING NETWORK}

\subsubsection{Direct monitoring}

The groundwater monitoring network consists of four monitor wells downgradient from the disposal cell at the POC (DOE monitor wells 548, 549, 575, and 580). These monitor wells are completed in the weathered granodiorite. These wells will be used for baseline groundwater quality monitoring at the POC. In addition, an on-site perennial spring (monitor station 561) will be monitored for surface water quality. Background groundwater quality will continue to be monitored upgradient from the disposal cell using wells 583 and 641 . This monitoring network is shown in Figure 5.3. Well location data, monitor well completion records, and construction logs for these wells are available in the permanent site file. Table 5.3 lists the depths of the well-screened intervals.

\subsubsection{Monitor well installation and development}

The monitor wells used for long-term surveillance monitoring at the disposal site were installed and developed in accordance with procedures described in the UMTRA Project standard operating procedures (SOPs), ensuring that appropriate data are collected with adequate QA (TAC, 1985). The monitor well completion records are available in the UMTRA Project Office permanent site file.

\subsubsection{Indirect monitoring network}

Indirect monitoring is not necessary for the Lowman site.

\subsection{GROUNDWATER MONITORING PROGRAM}

The groundwater monitoring program was developed in consultation with the NRC and the state of Idaho. The plan is designed to demonstrate that the initial performance of the disposal cell is in accordance with the design requirements. The program will monitor the uppermost aquifer including analyzing groundwater samples from a series of monitor wells downgradient from the disposal cell at the POC and upgradient from the disposal cell as background. This direct monitor well 
Table 5.3 Groundwater monitoring well network, Lowman, Idaho, disposal site

\begin{tabular}{|c|c|}
\hline Well number & $\begin{array}{c}\text { Screened interval } \\
\text { (depth below land surface) }\end{array}$ \\
\hline \multicolumn{2}{|l|}{ Upgradient } \\
\hline 583 & $\begin{array}{l}180.5-195.5 \mathrm{ft} \\
(55.0-59.5 \mathrm{~m})\end{array}$ \\
\hline 641 & $\begin{array}{c}117-137 \mathrm{ft} \\
(35.7-41.8 \mathrm{~m})\end{array}$ \\
\hline \multicolumn{2}{|l|}{ Downgradient } \\
\hline 548 & $\begin{array}{c}55-75 \mathrm{ft} \\
(16.8-22.9 \mathrm{~m})\end{array}$ \\
\hline 549 & $\begin{array}{c}46.5-56.5 \mathrm{ft} \\
(14.2-17.2 \mathrm{~m})\end{array}$ \\
\hline 575 & $\begin{array}{c}37-47 \mathrm{ft} \\
(11.3-14.3 \mathrm{~m})\end{array}$ \\
\hline 580 & $\begin{array}{c}39-59 \mathrm{ft} \\
(11.9-18.0 \mathrm{~m})\end{array}$ \\
\hline
\end{tabular}

network is discussed in Section 5.2.1 of this report. Performance monitoring frequency is outlined in Section 5.3.1 of this report. The constituents to be monitored are listed in Table 5.1 .

All aspects of the groundwater monitoring program will be conducted in accordance with accepted industry $\mathrm{OA}$ practices, including directives in DOE Orders $5700.6 \mathrm{C}$ and 5400.1. The general sequence for conducting the groundwater monitoring program is provided in Figure 5.4 .

\subsubsection{Sampling frequency}

The schedule for groundwater sampling takes into account such factors as background groundwater quality, the geochemistry of the radioactive sand pore fluid solution, groundwater flow rate, the possibility of seasonal variations in groundwater quality, and risk to human health and the environment. Information regarding these factors is presented in the Lowman RAP (DOE, $1991 \mathrm{~b}$ ).

In addition to collecting groundwater samples, groundwater levels will be measured prior to sampling each well. The resulting water-level data will be examined periodically to estimate groundwater flow rate and direction to ensure that no significant hydrologic change has occurred that could affect groundwater monitoring. 


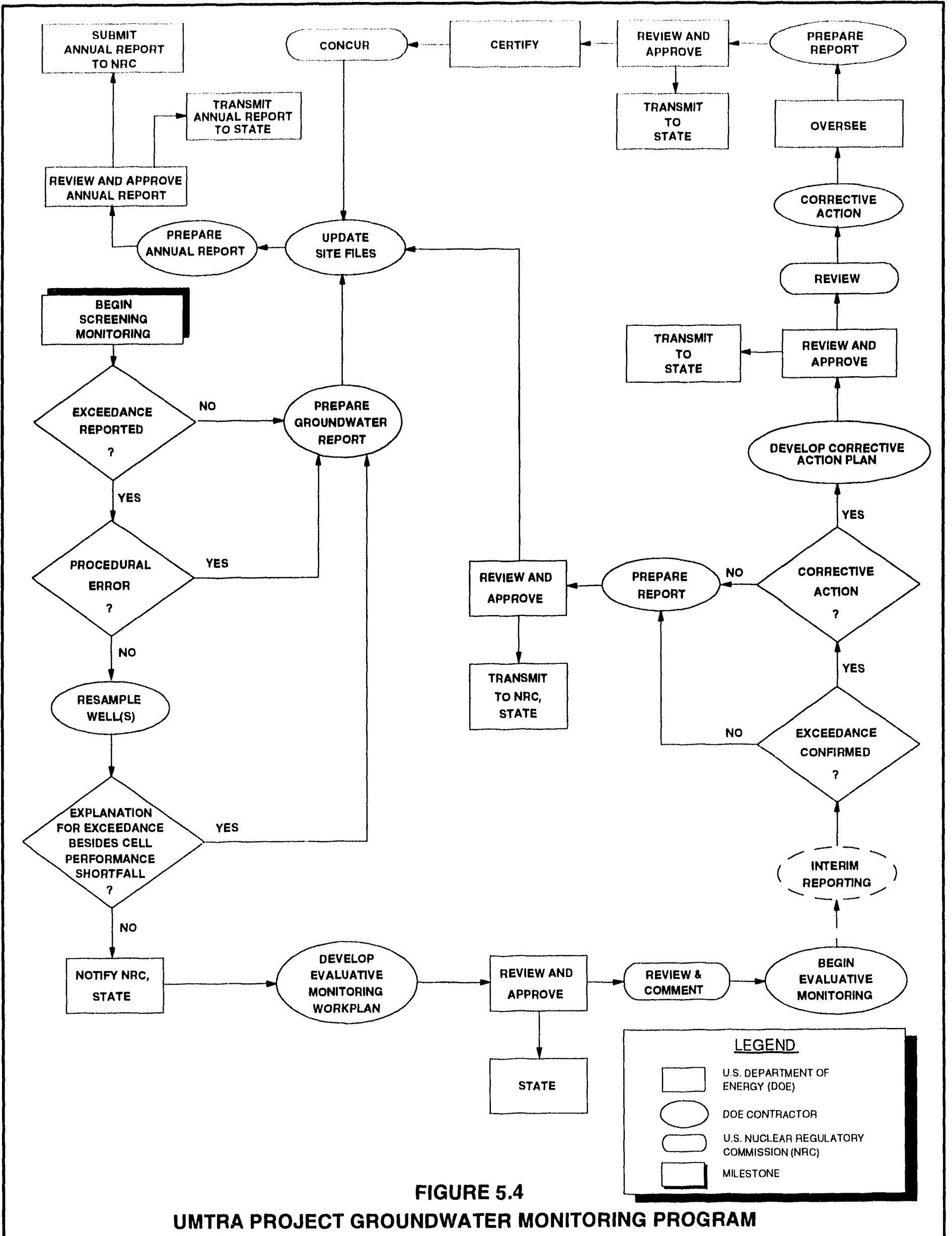

(DOF, 1992) 
Based on the previously defined background water quality conditions at the site, quartorly sampling has been reduced to ammually at POC, background, and downgradient monitor wells. Annual sampling will be conducted through 1995. This frequency is subject to change based on recommendations presented in the Lowman WSAP. Sampling will be conducted approximately at the same time of the year, each year, for consistency.

Performance evaluations will be conducted periodically to determine the following:

- The effectiveness of the disposal cell groundwater compliance strategy.

- The effectiveness of the groundwater monitoring plan (i.e., groundwater monitor well network, sampling frequency, analytes measured).

- The need for continued monitoring.

Monitoring data will be reviewed and analyzed, and recommendations will be presented in the Lowman WSAP. This approach will provide the flexibility necessary to respond to new information and changing conditions. Performance evaluation reports will be presented to the NRC and the state of Idaho for comments. The statistical methods described in the EPA's Statistical Analysis of Groundwater Monitoring Data at RCRA Facilities - Interim Final Guidance (EPA, 1989 ) or other appropriate methods will be applied as necessary.

\subsubsection{Screening monitoring and exceedence validation}

During the established groundwater monitoring period, screening monitoring will be conducted to observe possible changes in groundwater quality and to assess cell performance. Screening monitoring involves routine water-quality data collection, data evaluation, and possible resampling. Exceedences in concentration limits are evaluated on a well-by-well and analyte-by-analyte basis. If the maximum background concentration presented in Table 5.1 is exceeded, the appropriate steps will be taken as specified in Section 5.3.2 of the Guidance for Implementing the UMTRA Project Long-term Surveillance Program (DOE, 1992).

\subsubsection{Evaluative monitoring}

In cases where sampling, evaluation, and resampling performed during screening monitoring cannot rule out the disposal cell as the cause for the water-quality exceedence, additional field and evaluation work ("evaluative monitoring") may be required. This work is to be conducted to determine with greater surety whether the disposal cell is the cause and, if so, the nature and extent of the exceedence. Evaluative monitoring will involve the procedures described in Section 5.3.3 of the Guidance for Implementing the UMTRA Project Long-term Surveillance Program (DOE, 1992). 


\subsubsection{Indirect monitoring}

The DOE will conduct direct monitoring of groundwater at the Lowman disposal site, as specified in Section 5.2.1. Indirect monitoring is not necessary for the Lowman disposal site. Direct monitoring is considered sufficient to provide early detection of hazardous constituents released from the disposal cell and will detect notable changes in background groundwater quality.

\subsection{CORRECTIVE ACTION}

The EPA's proposed standards 140 CFR 192.02(c)/ require that a corrective action program be implemented within 18 months after verifying that the established concentration limits for one or more of the monitored constituents have been exceeded. The goal of the corrective action program is to restore the disposal cell to the design requirements. NRC regulations [10 CFR 40.27(c)/(5)] specify that the DOE will notify the NRC prior to implementing any significant action(s) that may be required. Section 9.0 provides guidance for implementing a corrective-action program.

If a determination has been made that corrective action is necessary, the DOE will prepare and submit a corrective action plan to the NRC for review. A copy of this plan also will be transmitted to the state of Idaho. The corrective action plan will include a monitoring program to demonstrate the effectiveness of the corrective action. The DOE will implement the corrective action after consultation with the NRC and the state of Idaho.

As a part of evaluative monitoring, a risk assessment may be performed to evaluate the potential harm from the exceedence to human health or the environment. If the risk assessment demonstrates no potential harm exists, the corrective action may involve no action except continued monitoring.

\subsection{DATA VALIDATION AND QUALITY ASSURANCE}

The UMTRA Project has established SOPs for monitor well installation and development, water sampling, sample preservation and transport, field procedures, and chain of custody.

$\mathrm{QA}$, quality control $(\mathrm{QC})$, analytical data management, and validation will be detailed in the Quality Assurance Implementation Plan, which is being developed in accordance with DOE Order 5700.6C, Quality Assurance.

Compliance groundwater monitoring at the Lowman disposal site will remain the responsibility of the UMTRA Project Office until the Lowman UMTRA site comes under the NRC general license. During this time, all aspects of groundwater monitoring will be conducted in accordance with these procedures and will be updated regularly to reflect changes in industry standards, best management practices, or guidance from the EPA. The QA procedures described in this section 
are consistent with the RCRA Groundwater Monitoring Technical Enforcement Guidance Document IEPA, 1986).

Upon licensing, the responsibility for groundwater monitoring at the Lowman disposal site will be transferred to the GJPO. It will then be the GJPO's responsibility to establish procedures and to develop a $Q A / O C$ program that is consistent with EPA guidance. (Section 12.0).

Sections 5.6.1 through 5.6.4 in the Guidance for Implementing the UMTRA Project Long-term Surveillance Program IDOE, 1992), summarize standard OA procedures that will be followed for water sampling, analytical $Q C$, analytical $O A$, and analytical data validation.

\subsection{REPORTING}

The data and results of the groundwater monitoring program will be reported annually to the NRC (Section 10.0). The following information will be included in the Lowman LTSP annual monitoring report:

- A table of concentration limits for hazardous constituents.

- A table comparing water quality to concentration limits.

- A summary of any exceedences of concentration limits.

- Water-quality or water-level data land indirect monitoring data, should it ever become necessary for evaluative monitoringl.

- A summary of any resampling, trends, exceedences, evaluative monitoring, or corrective actions required during the reporting period.

- Any significant trends or anomalies in the water-quality and water-level data. The narrative will include a comparison of collected data to preestablished baseline values.

- Any significant changes in the local hydrology.

- The methods for interpreting water quality or indirect monitoring data trends.

- The qualitative or statistical procedure selected to compare groundwater quality results with preestablished baseline values.

- A discussion of any new wells or indirect monitoring staticits that may have been installed, including the rationale for their installation and all completion data.

- All completed field and laboratory forms. 
In addition to the annual monitoring reports, five-year performance evaluation reports will be provided for the Lowman disposal site. The purpose of these status reports is to evaluate the effectiveness of the disposal cell. The five-year performance evaluation reports will, at a minimum, include the following:

- Review historic screening compliance monitoring data.

- Summarize trends in water levels and water quality.

- Include a statistical analysis of historical data, as necessary.

- Evaluate the performance of the disposal cell.

- Determine the effectiveness of the groundwater monitoring plan and whether or not the plan should be modified.

- Determine if the remedial action is complete.

The UMTRA Project Office will submit these reports to the NRC and the state of Idaho in compliance with the environmental monitoring requirements of DOE Order 5400.1. All groundwater monitoring data and supporting documentation will bo part of the permanent site file. The UMTRA Project Office will be responsible for the preparation of these reports until the site transfer of responsibility is complete for the GJPO. 


\subsection{SITE INSPECTIONS}

Inspections of the Lowman sito will result in preparation of a status leport on the disposal coll, recording any changes or modifications to the disposal cell and disposal cell sito over time and identifying potontial problems at an early stage pror to the noed for oxtensive maintenance, repairs, or corrective action. A fundamental part of the inspestion will bo the detection and documentation of progressive change over a number of voars as a result of slowly acting natural processes. The findings recorded during these inspections, when compared against the initial baseline conditions, will provide a basis for conducting future inspections. The three types of site inspections are as follows:

- Annual or scheduled site inspecitions.

- Follow-up inspections.

- Contingency inspections.

Each site inspection must be documented in a report that identifies the findings of the inspection. Copies of each inspection report will be submitted to the NRC and the state of Idaho and placed in the Lowinan site file. Annual or scheduled site inspection reports will be completed and submitted to the NRC within 90 days of the last UMTRA Program site inspection of that calendar year. Follow-up or contingency inspection reports must be submitted to the NRC within 60 days of the initial report.

\subsection{INSPECTION FREQUENCY}

Annual site inspections at the Lowman site will be conducted for the first 6 years following licensing. At the end of the 5-year period, the G.JPO will evaluate the need to continue conducting inspections on an annual basis. The recommendation will be based on an evaluation of the annual reports and any other reports that have been filed due to the need for maintenance or unscheduled events. If a determination is made that less frequent inspections are required, the GJPO will modify the LTSP and submit it to the NRC for acceptance. The state of Idaho will also receive copies for review. Subsequent inspections would be considered scheduled site inspections.

\subsection{INSPECTION TEAM}

The inspection team will consist of a chief inspector and one or more assistants. The chief inspector will be a geotechnical engineer, a civil engineer, or an engineering geologist knowledgeable in the processes that could adversely affect the site (e.g., identifying goomorphic agents of change).

Whore necessary for follow-up or assessment inspections, the team will include additional technical experts appropriate to the problems under investigation. 


\subsection{PREPARATION FOR INSPECTION}

Prior to conducting an inspection, inspectors will complete the following tasks:

- Review the final LTSP, the permanent site file, the previous site inspection report(s) and site inspection map(s), and any maintenance or corrective action reports.

- Prepare the site inspection checklist based on previous inspections or repairs; incorporate any modifications that may be needed.

- Verify and update the names and telephone numbers of all parties with whom access or notification agreements have been executed.

- Verify the DOE 24-hour telephone number and appropriate agency telephone numbers and contacts. Arrange to change the entrance sign, as needed.

- Schedule the site inspection.

- Notify the NRC, the state of Idaho, and adjacent landowners for possible attendance at the inspection.

- Assemble the equipment needed to conduct the inspection.

- Adjust the Brunton compass's magnetic declination for that of the Lowman area (currently 18.5 degrees east of true north).

\subsection{SITE INSPECTION AND INSPECTION CHECKLIST}

The site inspection will cover the disposal site area, the disposal cell, and the immediate off-site areas. All site inspection activities and observations are to be recorded and described using the as-built drawings, initial site inspection checklist (Attachment 5), site inspection map, a field notebook, and photographs. Observations and photographic stations should be recorded on the field maps. After the inspection is complete, these maps are to be drafted and retained in the permanent site file.

The initial site inspection checklist (Attachment 5 ) is a guideline for the inspectors during their inspection. At the completion of each inspection, the checklist will be revised to include new information or to delete items that are no longer pertinent. Revisions to the checklist will be documented in the inspection report.

A photographic record of the site inspection must be maintained. Site conditions are to be documented by ground photographs to provide a record of developing trends and to enable the DOE to evaluate the need for and extent of future activities. Any site feature or condition that requires the inspectors to make a written comment, explanation, or description will be photographed, if possible. A 
site inspection photo log will be used for rocording the photocgraphs (Allachment 4 ). All loatures will be photographed and reconded as specolied in Section 3.4. The number of photographs, the view angles, and the lonses used are up to the judgement of the inspectors, as long as sufficient photographs are taken for agency reviow.

\subsubsection{Off-site areas}

The area within $0.25 \mathrm{mi}(0.4 \mathrm{~km})$ of the perimeter of the disposal site will be surveyed for evidence of land use changes indicating increased human activity that could increase the probability of intrusion onto the site; or new roads or paths, changes in vegetation, or relevant geomorphic features le.g., gullies or aeolian formations) that could initiate site-threatening erosion.

\subsubsection{On-site areas}

A series of transects around the perimeter of the disposal site; along the base, crest, and sideslopes of the disposal cell; and in and around the diversion channels will be made to evaluate the integrity of the disposal cell site. Sufficient transects must be walked so that the disposal site area is thoroughly covered and inspected. Diagonal transects of the crest will be made, and the edge of the crest will be walked. Additional transects, at approximately 50 -yd $(46-\mathrm{m})$ intervals, will be walked along the sideslopes. Transects along the entire length of each diversion channel will be made to determine whether the channels have been functioning and can be expected to continue to function as designed. Design of the drainage ditches and swales can be found in the Morrison Knudsen Engineers, Lowman, Idaho, Subcontract Documents, Final Design for Ruview, Calculations, Volume IV (DOE, 1992).

At a minimum, the site perimeter and site area transects will be monitored for damage or disturbance to the following features:

- Site perimeter roads.

- Fences, gates, and locks.

- Permanent site surveillance features.

- Groundwater monitor wells.

- Site area vegetation or volunteer plant growth.

- Sedimentation or erosion.

Transects along the engineered component (diversion channols, cell sideslopes, cell crest, and cover) will be walked along their complete length and examined for ovidence of the following:

- Structural instability due to differential settlement, subsidence, cracking, sliding, or creep. 
- Erosion as evidenced by the development of rills or gullies.

- Sedimentation or debris.

- Rapid deterioration of the rock cover caused by weathering or erosion.

- Removal of rock or other disposal cell material.

- Seepage.

- Intrusion (inadvertent or deliberate) by humans or animals.

- Animal burrowing.

- Vandalism.

- Development of trails from human or animal activity.

- Volunteer plant growth.

\subsubsection{Modifying processes}

The elevation and location of the site are such that flooding on the South Fork Payette River or Clear Creek poses no threat to the integrity of the radioactive sand pile.

The rock riprap layer on the embankment slopes has been designed to prevent erosion due to runoff resulting from the 1 -hour probable maximum precipitation event. The cell is protected from gully intrusion by the large rock apron at the perimeter of the cell. The roadway above the cell was backfilled and mulched to maintain slope stability.

No erosion control monitoring features are required; however, future inspection teams should pay particular attention to the formation of any gullies above or alongside the disposal cell. Should gullies approaching $3 \mathrm{ft}(0.9 \mathrm{~m})$ in depth approach the disposal cell, a follow-up inspection will be scheduled to analyze the situation and determine what action, if any, is required.

Inadvertent or casual intrusion by humans or animals is not of great concern, but evidence of removal of the cover, extensive vandalism to signs and monuments, or the presence of well-established trails should be described in detail. Continuing vandalism to the site may require more active measures to control access to the site.

If new conditions requiring continuing observation, monitoring, or immediate action are discovered during the inspection, the inspector shall attempt to quantify the 
observed conditions and identify an appropriate level of action for subsecumont inspections.

\subsubsection{Vegetation}

The top of the embankment is sloped and covered with riprap. No vegetative growth was noted on the riprap surface. If vegetation becomes established in the erosion protection features, integrity of the features will be assessed and a determination will be made of the need to remove the vegetation.

North of the disposal site is a large mulched area and to the west of the site is a mulched area bordered by fairly steep terrain leading down to Clear Creek. Establishment of vegetation at these locations will be monitored during site inspections.

The annual inspection team will determine the need for further assessment of vegetative conditions by a plant specialist.

\subsection{SITE INSPECTION MAP}

A new site inspection map will be prepared following each scheduled inspection using the disposal site map (Plate 1 ) as a base. This map must include the following:

- Inspection traverses.

- Photographic locations.

- Locations and descriptions of any new, anomalous, or unexpected features.

- Features identified during previous inspections for observation or monitoring.

- Date of inspection.

\subsection{REPORTING REQUIREMENTS}

Upon completion of the field inspection, Section D of the initial site inspection checklist (Attachment 5) must be completed and the certification statement signed. Overlays for the as-built drawings or revised drawings should be developed that note any potential problems or other site conditions that may require future attention. The revised drawings should be labeled with the type of site inspection and the date the site inspection was performed.

All photographs must be logged on a site inspection photo log (Attachment 4). A separate photo log should be completed for each roll of film exposed, wilh an entry made for each photograph taken. The completed photo logs are to be attached to the inspection checklist and paginated accordingly. 
Documentary evidence of anomalous, new, or unexpected conditions or situations must be uncluded to provide a record of developing trends and to enable the responsible agency to make reasonable decisions concerning follow-up inspections, custodial maintenance, repair, and corrective action. Photographs may be used to provide such evidence.

A site inspection report with the following information will be prepared following every routine site inspection:

- Narrative of site inspection, results, conclusions, and recommendations.

- Site inspection checklist and any relevant supporting documentation.

- Site inspection map and other drawings, maps, or figures, as required.

- Inspection photographs and photo log sheet.

- Recommendations for additional follow-up inspections, repair, or custodial maintenance, if required.

- Follow-up or contingency inspection reports, if required.

- Custodial maintenance or repair report and certification, if required.

- Inspection certification.

- Groundwater monitoring data and analyses, if applicable.

Criterion 12 of 10 CFR 40 requires that the DOE submit the results of all routine site inspections to the NRC within 90 days of the last UMTRA Program site irispection for that calendar year. A copy of all site inspection reports will be maintained in the permanent site file. A copy of the inspection report will also be sent to the state of Idaho. 


\subsection{UNSCHEDULED INSPECTIONS}

Unscheduled inspections arise from reports or information indicating that site integrity has been or may be compromised. The need for an unscheduled inspection may be triggered by any of the following:

- Findings from an annual or scheduled site inspection.

- Other site visits, such as for groundwater sampling, special studies, corrective action, or other DOE activities.

- Reports from law enforcement agencies or the public.

- Reports from the Earthquake Early Warning Service or the National Weather Service (NWS).

\subsection{FOLLOW-UP INSPECTIONS}

Follow-up inspections are conducted to investigate and quantify specific site problems detected during a scheduled inspection, groundwater sampling event, special study, or other DOE activity. They are necessary to assess whether processes currently active on or near the site pose any future threat to the site if left unmodified and are required to evaluate the need for custodial maintenance, repair, or corrective action.

Follow-up inspections are to be made by technical specialists in the discipline appropriate to the problem that has been identified. For example, if erosion is the problem, the inspector(s) will be knowledgeable in evaluating erosion, presumably a soils scientist or geomorphologist. If settlement or sliding is the problem, a geotechnical engineer would be the appropriate inspector.

The first step of the follow-up procedure will be an on-site visit to gather firsthand knowledge for the development of a plan of action to conduct the tests or studies necessary to understand the phenomenon in progress. Additional visits may then be scheduled to gather the data needed to draw conclusions and recommend corrective action.

Upon completion of the follow-up inspection, the DOE will analyze the information gathered; make an assessment of the situation; prepare an inspection report describing the site conditions; and, if necessary, make recommendations for further action. If maintenance, repair, or corrective action is warranted, the DOE will notify the NRC, the state of Idaho, and the adjacent residents as specified in Section 9.0. 


\subsection{CONTINGENCY INSPECTIONS}

Contingency inspections are unscheduled inspections ordered by the DOE when it receives outside information indicating that site integrity has been or may be threatened. Trigger events for contingency inspections may include reports of severe vandalism, intrusion by humans or livestock, severe rainstorms or floods, or unusual events such as tornadoes or earthquakes.

Contingency inspections will be carried out in two or more steps. The first step will be an on-site visit to gather firsthand knowledge for the development of a plan of action to conduct the tests or studies necessary to understand the phenomenon in progress. Additional visits may then be scheduled to gather the data needed to draw conclusions and recommend corrective action.

Once the DOE has been notified of an unusual event, an assessment of the situation is required by 10 CFR 40 to be submitted to the NRC within 60 days of the initial report that damage or disruption has occurred at the Lowman disposal site. The state of Idaho will also receive a copy of this report. At a minimum, this report must include the following:

- A description of the problem.

- A preliminary assessment of the maintenance, repair, or corrective action required.

- Conclusions and recommendations.

- Assessment data, including field and inspection data, and photographs.

- Field inspector names and qualifications.

A copy of the report, and all other data and documentation, will be maintained in the permanent site file. The annual report to the NRC will also include the results of these contingency inspection reports. If appropriate, the annual (or scheduled) Lowman site inspection report will also contain the results of these inspections.

After the preliminary inspection/assessment report has been reviewed, the DOE must submit a corrective action plan to the NRC for approval and to the state of Idaho within the 60-day period required by 10 CFR 40 . Based on the findings of these reports, the GJPO will complete the corrective actions needed according to the guidance for implementing a corrective action described in Section 9.0. 


\subsection{CUSTODIAL MAINTENANCE}

Custodial maintenance will be performed at the Lowman site on an as-needed basis. Unscheduled maintenance or repairs may be required based on the recommendations from annual site inspections, follow-up inspections, or contingency inspections.

\subsection{PLANNED MAINTENANCE}

No routine maintenance is planned for the Lowman disposal site.

\subsection{UNSCHEDULED MAINTENANCE OR REPAIR}

Unscheduled custodial maintenance activities that may be required at the Lowman disposal site include the following:

- Repair the gate.

- Replacement of entrance signs.

- Replacement of perimeter warning signs.

- Reestablishment of survey control and boundary monuments.

- Repairs due to animal burrows on the disposal cell.

- Removal of volunteer plant growth on the disposal cell or in the diversion channels.

For these types of custodial actions, the GJPO will prepare a purchase order statement of work authorizing the repair and including contractor qualifications.

If any problems are identified that indicate that the integrity of the disposal cell or compliance with 40 CFR 192 may be affected, the recommended repair action must be approved in advance by the NRC and will be treated as a corrective action.

\subsection{CERTIFICATION AND REPORTING REQUIREMENTS}

The following information on unscheduled maintenance or repair must be provided in the site inspection report and included in the annual report to the NRC:

- Summary of work required.

- Work order, purchase order, or statement of work.

- Contractor qualifications, if applicable.

- Contractor documentation of completion of work. 
- DOE certification of completion of work.

After completion of the work, the contractor must submit verification of the completed work and/or a written report if the action is considered significant. The DOE will inspect the site, as necessary, and review the report before certifying that all work is completed in accordance with any required specifications. Copies of all records, documentation, and certifications must be included in the permanent Lowman site file. Copies of all relevant documentation will also be transmitted to the state of Idaho. 


\subsection{CORRECTIVE ACTION}

In the unlikely situation that natural or unforeseen events threaten the stability of the disposal cell, a corrective action that could include temporary emergency measures would be carried out to correct the problem. In addition, the DOE would evaluate the factors that caused the problem and ensure that recurrence is minimized or avoided.

Once a potential problem has been identified, the DOE will notify the NRC and the state of Idaho and submit an inspection/preliminary assessment report to the NRC for review within 60 days of problem identification. The preliminary assessment report will evaluate the problem and will provide recommendations for the next step (e.g., immediate action or continued evaluation). After the NRC has reviewed the report and recommendations, the DOE will develop a corrective action plan and submit it to the NRC for approval. The DOE may also choose to combine the inspection and recommendation in one report, depending on the severity of the problem. Once the NRC has approved the corrective action, the plan will be implemented by the DOE. Figure 9.1 illustrates the general sequence of events in the corrective action process, and Figure 9.2 identifies the key elements in the corrective action process.

The NRC regulations do not specify a time frame for implementing corrective action. However, the proposed EPA groundwater regulations, 40 CFR 192.02 (c), require that a corrective action program be placed into operation no later than 18 months after confirming that an exceedence is attributable to disposal cell performance. Assessing the extent of the problem and developing a corrective action plan will not be considered initiation of the corrective action program. Section 9.0 of the UMTRA LTSP guidance document (DOE, 1992) contains further details on corrective actions.

\subsection{PROBLEM IDENTIFICATION}

Site inspections by qualified inspectors and routine custodial maintenance are designed to identify potential problems at the developmental stage, thus eliminating the need for corrective action. However, it is recognized that extreme natural events may occur, that vandalism may affect the surface, or that unanticipated events may occur. Additional data collection or evaluative monitoring may be needed to assess whether the processes associated with the problem would pose any future threat to the site if left unmodified. The initial step in identifying the problem could include one or more on-site inspections. The inspection/preliminary assessment would include, but not be limited to, the following:

- Quantifying the nature and extent of the problem.

- Reevaluating the engineering design parameters germane to the problem.

- Establishing a data collection and/or evaluative monitoring program to quantify the magnitude of the problem. 
PROBLEM INDICATING CORRECTIVE ACTION IDENTIFIED

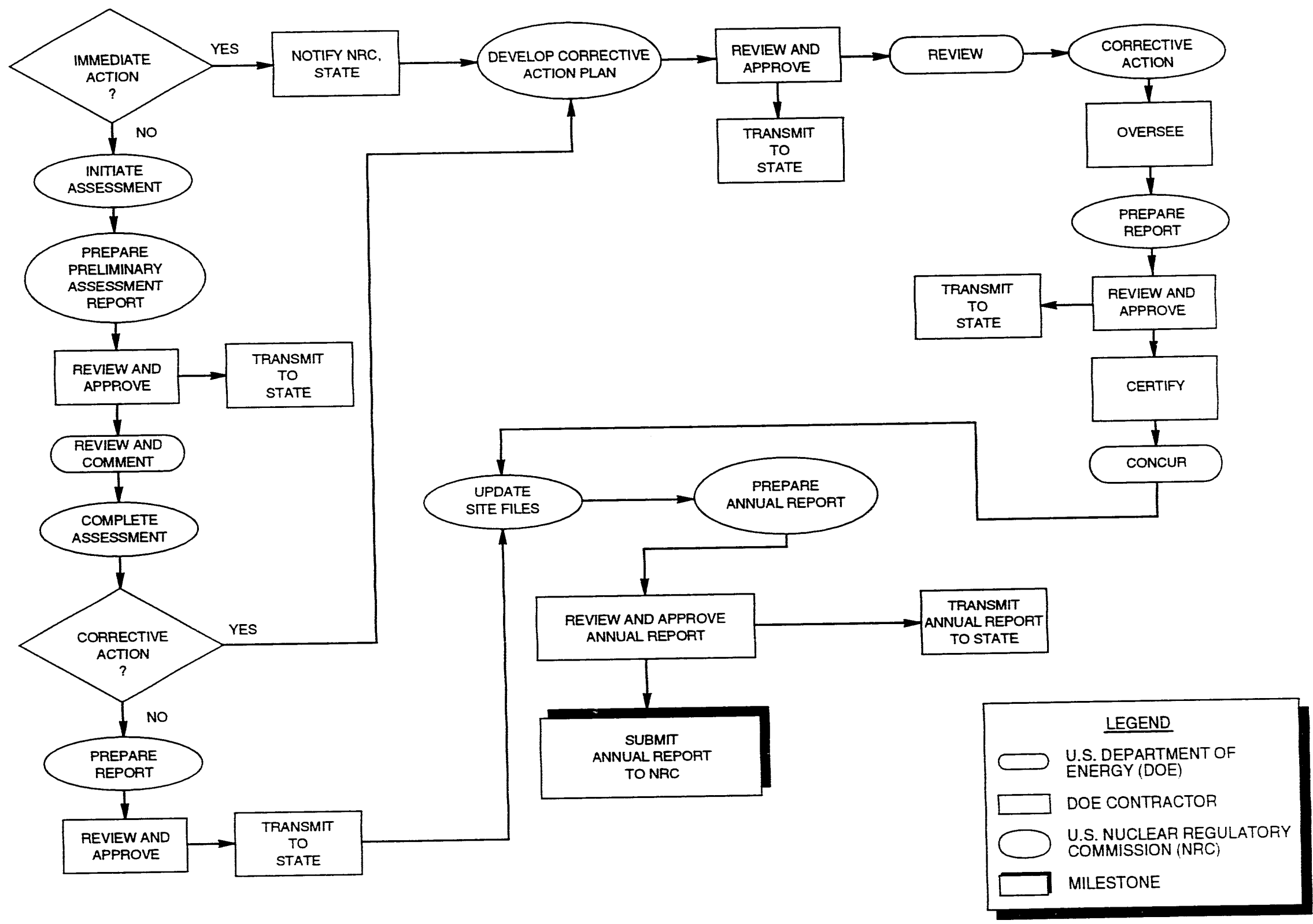

FIGURE 9.1

CORRECTIVE ACTION

UMTRA PROJECT LONG-TERM SURVEILLANCE PROGRAM 


\section{NEED FOR CORRECTIVE ACTION IDENTIFIED}

- DOCUMENT AND REPORT PROBLEM TO NRC, STATE, AND TRIBES

- eVAlUate PROBLEM AND PROPOSE a SOLUTION

- DEVELOP CORRECTIVE ACTION PLAN AND NOTIFY NRC, STATE

- SELECT CONTRACTOR TO PERFORM CORRECTIVE ACTION

- ESTABLISH CONTRACTUAL CONDITIONS FOR PERFORMING CORRECTIVE ACTION AND GUARANTEE CORRECTIVE ACTION WILL. BE PERFORMED IN ACCORDANCE WITH CONTRACTUAL AGREEMENTS AND DESIGN SPECIFICATIONS
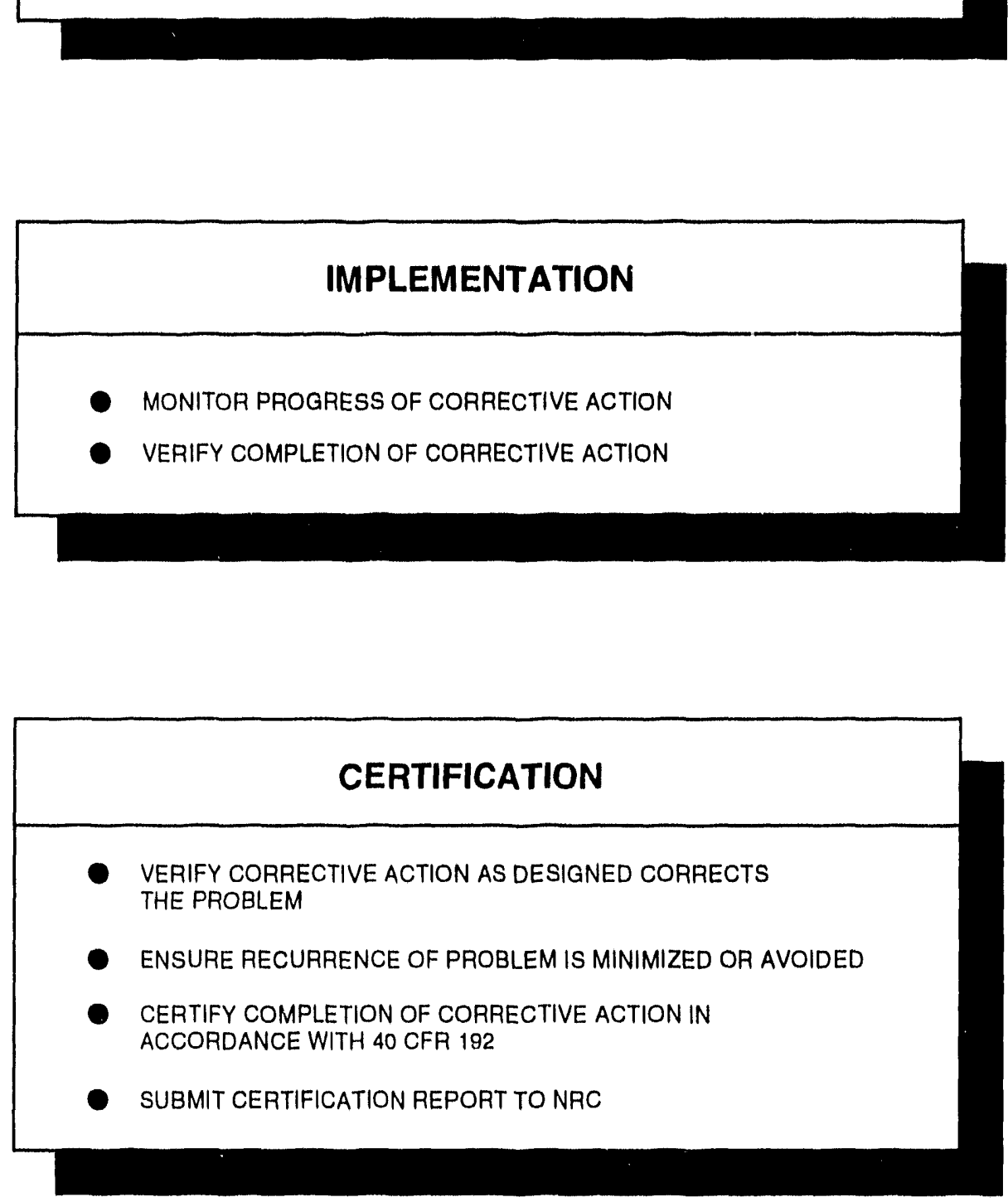

FIGURE 9.2

KEY ELEMENTS IN THE CORRECTIVE ACTION PROCESS 


\subsection{CERTIFICATION AND REPORTING REQUIREMENTS}

While a corrective action is being performed or evaluated, the DOE will prepare progress reports on the corrective action. The NRC will be given a copy of each report, or the roport will be attached to the annual roport. In any event, the NRC will be apprised of the problem and the solution that is being evaluated. All reports will be provided to the state of Idaho.

After completion of the corrective action, all work completed will bo certified in accordance with the design specifications and in accordance with the EPA standards. The NRC will review the certification that the corrective action is acceptable. A copy of the certification statement will become part of the permanent site files. All reports, data, and documentation generated during the corrective action will be included in the permanent site file. 


\subsection{RECORD KEEPING AND REPORTING REQUIREMENTS}

A permanent site file maintained by the DOE will contain all the information nocessary to prepare for and conduct situ surveillance. Carefully compiled, complete, accurate reports of site surveillance activities will be maintained in accordance with archival procedures set forth in CFR, Title 41, Public Contractors and Property Management; Chapter 101, Federal Property Management Regulations; Subchapter B. Archives and Records; Section 101.11. Records Management (41 CFR 101.11).

As required by 10 CFR 40.27 , the DOE will provide an annual report to the NRC documenting the results of the long-term surveillance program. Copies of the annual report will be provided to the state of Idaho and will be added to the permanent Lowman site file. The annual reports and supporting documentation in the permanent site files will

- Document the history of disposal site performance.

- Demonstrate to the NRC that license provisions continue to be met.

- Provide the DOE and the NRC with the information necessary to forecast future disposal site surveillance and monitoring needs.

- Provide information to the public to demonstrato that site integrity has been maintained.

\subsection{RECORDS}

The permanent Lowman site file will be maintained by the G.JPO in Grand Junction, Colorado. Tho original deeds, custody agreements, and other property documents will be kept in the DOE Facilities and Property Management Division, Albuquerque, New Mexico. Copies of these documents also will be maintained in the GJPO files.

Surveillance and maintenance documentation maintained at the GJPO will exist as a record collection separate from the UMTRA Project Document Control Center. As such, the records will be handled in accordance with DOE Order 1324.2A to ensure proper handling, scheduling, and disposition of the documents.

All information will be available for review by the NRC and the public. The Lowman permanent site file will include the following:

- Licensing documentation.

- The LTSP.

- Disposal site legal description, custody documentation, and cooperative agreements. 
- Interagency agreements, authorizations, and access ag̣oements.

- Documontation of rights of entry.

- EA and Finding of No Significant Impact.

- Disposal site characterization report and processing site characterization report.

- Final RAP and final design for construction.

- Pertinent design and construction documents and drawings.

- Site certification report (certification summary, completion, and final audit reports).

- As-built drawings.

- Site atlas (vicinity, topographic, and base maps).

- Baseline and aerial photographs.

- Groundwater monitoring reports and records.

- Additional monitoring reports and records.

- Monitor well permits and abandonment records.

- Annual reports to the NRC.

- Annual inspection reports and records.

- Follow-up or contingency inspection preliminary assessments, reports, and records.

- Custodial maintenance or repair reports and records.

- Corrective action plans, reports, and records.

- oA program plan.

The permanent Lowman site file will be updated, as necessary, after completing the annual disposal site inspections. Original UMTRA Project records and files will be archived with the DOE UMTRA Project Office, Albuquerque, New Mexico. Copies of the documentation and annual updates, and additions will be kept in the permanent site file held by the GJPO, Grand Junction, Colorado. 


\subsection{REPORTS}

The GJPO will provide an annual report to the NRC, documenting the results of the annual site inspections and any other activities conducted in conjunction with the long-term surveillance program. Criterion 12 to Appendix A of 10 CFR 40 requires that the annual report be submitted within 90 days after the date of the last UMTRA Program site inspection for that calendar year.

The GJPO will also submit reports to the NRC documenting follow-up or contingency inspections and any corrective action plans. If any unusual damage or disruption is discovered, Criterion 12 requires that all preliminary inspection reports be submitted within 60 days of the discovery.

The results of the groundwater monitoring program will also be reported to the NRC annually. The UMTRA Project Office will be responsible for preparing these groundwater monitoring reports until this responsibility is transferred to the GJPO. 


\subsection{EMERGENCY NOTIFICATION AND REPORTING}

The Lowman disposal cell was designed to comply with 40 CFR 192 with minimum maintenance and oversight for a period of 1000 years, or at least 200 years. However, due to unforeseen events, problems could develop that affect the disposal cell's ability to remain in compliance with $40 \mathrm{CFR}$ 192. Because of this possibility, the DOE has notified state and Federal agencies requesting notification of any purposeful intrusion or damage discovered or reported at the Lowman disposal site as well as the occurrence of an earthquake, tornado, or flood in the Lowman disposal site area.

\subsection{AGENCY AGREEMENTS}

The DOE has negotiated notification agreements with the Boise National Forest, Lowman Ranger District; the U.S. Geological Survey (USGS) National Earthquake Information Center (Denver, Colorado); the Idaho State Office of the NWS (Boise, Idaho); and the Boise County Sheriff's Department. Copies of draft notification requests are presented in Attachment 5. The designated point of contact for emergency notification is the GJPO's 24-hour phone line (303) 248-6070. This phone number is also posted on the Lowman disposal site entrance signs so that members of the public can notify the DOE if problems are discovered.

The agreements shall be carried out in accordance with the requirements of DOE Order 5000.3B, Occurrence Reporting and Processing of Operations Information. In accordance with this order, the UMTRA Project Office will be the designated facility contact until the Lowman site is brought under the general license. After that, the designated facility contact will be the GJPO.

Returned response letters from all of the agencies will be kept in the permanent site files. Updating the contact lists and telephone numbers for all agencies with whom the DOE has enternd into agreements will be done annually, in conjunction with the site inspection, and included in the disposal site inspection report.

To further solidify written agreements with these agencies, the DOE GJPO shall periodically contact these agencies to update them about the location of and concerns for the Lowman disposal site.

\subsection{UNUSUAL OCCURRENCES}

The DOE has requested notification of unusual events at the Lowman site from the following agencies:

- Boise County Sheriff's Department: The DOE has requested that the GJPO be notified of any unusual occurrences in the disposal site area that may affect surface or subsurface stability. 
- Boise National Forest Lowman Rangor District: The DOE has requested that the GJPO be notified of any unusual occurtences in the site area that may affect surface or subsurface stability.

\subsection{EARTHQUAKES}

The DOE subscribes to the USGS Early Warning Service for notification when an earthquake of sufficient magnitude threatens a disposal site. This service provides data on the magnitude of the event and the location of the epicenter.

The USGS National Earthquake Information Center will notify the DOE GJPO if a seismic event(s) occurs that fits any of the following descriptions:

- Any earthquake of magnitude 3.0 or greater, within 0.3 degree labout $20 \mathrm{mi}$ $(30 \mathrm{~km}))$ of the site.

- Any earthquake of magnitude 5.0 or greater, within 1.0 degree labout $70 \mathrm{mi}$ $(110 \mathrm{~km})$ ) of the site.

\subsection{METEOROLOGICAL EVENTS}

The DOE will complete an agreement for a continuing reporting service with the Idaho State Office of the NWS in Boise, Idaho. The NWS will notify the DOE GJPO within 8 hours of issuance of a flash flood warning or a tornado warning in Boise County, Idaho. 


\subsection{QUALITY ASSURANCE}

Development of $Q A$ procedures specific to the UMTRA long-term surveillance program is the responsibility of the GJPO. The GJPO QA program plan should specify requirements for the following:

- Program planning.

- Program activities, including inspections, site maintenance, corrective action, and emergency responses.

- Monitoring that may be required.

- Qualifications and training of personnel.

- Surveillance and audits of program.

- Analytical OA.

- Analytical data valıdation.

All site inspections, monitoring data, records, photographs, maps, and other information related to the LTSP for the Lowman site are subject to formal and unannounced audits conducted by the DOE UMTRA Project Office or the NRC. Specific QA criteria have already been developed for aeria! photographs (DOE, 1992).

Groundwater rustoration will not be required at the Lowman disposal site. Therefore, QA activities are not necessary at this time. 


\subsection{PERSONNEL HEALTH AND SAFETY}

DOE Order 5480.1B, Environment, Safety and Health Program for DOE Programs, establishes personnel health and safety procedures for all DOE operations. After a disposal site is licersed and transferred to the GJPO, health and safety procedures for GJPO personnel and GJPO subcontractors will be the responsibility of the GJPO. The GJPO will determine health and safety requirements for its personnel in accordance with applicable orders and Federal regulations. Because the disposal cell was constructed to control $\mathrm{Ra}-226$ and $\mathrm{Rn}-222$ releases from the residual radioactive material to within regulatory standards 140 CFR 192.02(a)l, radiation exposure tracking and dosimetry badges are not needed.

\subsection{HEALTH AND SAFETY}

The inspector's health and safety training and certifications, the locations and telephone numbers for emergency medical and law enforcement facilities, and the facility contact 24-hour telephone number should be verified prior to a site inspection.

Specific safety concerns at the Lowman disposal site include slip, trip, and fall hazards; animal, snake, and insect bites; heat and cold stress; fire hazards; puncture and cut hazards; and driving hazards.

Electrical power lines cross the Lowman mill site. Any crane or drilling rig must keep a minimum distance of $34 \mathrm{ft}(10 \mathrm{~m})$ from the power lines during operation, and $16 \mathrm{ft}(5 \mathrm{~m})$ from the power lines in transit with the boom or derrick lowered. Additionally, buried utilities have not been searched and marked. A search for buried utilities must be conducted prior to any off-pile drilling.

\subsubsection{Emergency medical and law enforcement}

Emergency medical and local law enforcement agencies have been briefed on the scope of work at the Lowman disposal site during the long-term surveillance and maintenance phase. The pertinent 24 -hour emergency numbers are as follows:

- Fire: $\quad 911$ or $\quad 208) 259-3361$

- Ambulance: 911 or 1-800-632-8000

- Police/Sheriff: 911 or (208) 392-4411

Medical emergencies are coordinated through the County Sheriff's Office. Lowman has its own ambulance and several emergency medical technicianqualified residents. Residents with medical problems are taken to a clinic in Stanley, Idaho. The nearest hospital with an emergency room is St. Lukes, which is located in Boise, Idaho, approximately $73 \mathrm{mi}(120 \mathrm{~km})$ northeast of the disposal site. Boise also has a "life flight" capability for transporting people in need of 
emergency and/or immediate hospital care (DOE, 1991a). Directions to St. Luke's hospital from the site are as follows:

Travel south on State Highway 21 to Boise, Idaho. Make a right-hand turn on $1 \mathrm{st}$ Street and go two blocks, then turn left on Bannich. St. Luke's Hospital is located at the intersection of $1 \mathrm{st}$ and Bannich.

\subsection{REPORTABLE INCIDENTS}

The inspection team will be briefed by the GJPO health and safety officer on potential site hazards and other requirements prior to site inspections or any site visit.

In accordance with DOE Order 5000.3B, any accident, injury, or environmental event (e.g., tornado, flood, etc.) occurring during the site inspection is a reportable incident. The condition or event will be reported to the GJPO facility manager or designated contact within 8 hours of the accident. The GJPO facility manager's 24-hour telephone number for reporting an incident is (303) 248-6070. 


\subsection{REFERENCES}

BRR (Basin and Range Research), 1987. Class I/l Cultural Resources Survey, Lowman, Idaho, prepared by BRR, Boise, Idaho, for Jacobs Engineering Group Inc., Albuquerque, New Mexico.

DOE (U.S. Department of Energy), 1993. 1992 Annual Prelicensing Inspection of the Lowman, Idaho, UMTRA Project Disposal Site, DOE/ID/12584-124, prepared for the U.S. Department of Energy by Chem-Nuclear Geotech, Inc., DOE Grand Junction Projects Office, Grand Junction, Colorado.

DOE (U.S. Department of Energy), 1992. Guidance for Implementing the UMTRA Project Long-term Siırveillance Program, final, September 1992, UMTRA-DOEI AL-350125.0000, DOE UMTRA Project Office, Albuquerque Operations Office, Albuquerque, New Mexico.

DOE (U.S. Department of Energy), 1991a. Environmental Assessment of Remedial Action at the Lowman Uranium Mill Tailings Site, Lowman, Idaho, DOE UMTRA Project Office, Albuquerque Operations Office, Albuquerque, New Mexico.

DOE (U.S. Department of Energy), 1991b. Remedial Action Plan and Site Design for Stabilization of the Inactive Uranium Mill Tailings at the Lowman Site, Lowman, Idaho, DOE UMTRA Project Office, Albuquerque Operations Office, Albuquerque, New Mexico.

DOE (U.S. Department of Energy), 1989. Technical Approach Document, UMTRADOE/AL-050425-0002, Revision II, DOE UMTRA Project Office, Albuquerque Operations Office, Albuquerque, New Mexico.

EPA (U.S. Environmental Protection Agency), 1989. Statistical Analysis of Groundwater Monitoring Data at RCRA Facilities - Interim Final Guidance, EPA/530-SW-89-026, EPA Office of Solid Waste, Waste Management Division, Washington, D.C.

EPA (U.S. Environmental Protection Agency), 1986. RCRA Groundwater Monitoring Technical Enforcement Guidance Document, Division of Waste Management, Washington, D.C.

MKF (MK-Ferguson), 1992. "Draft Completion Report," Lowman, Idaho, prepared by MK-Ferguson for the U.S. Department of Energy, Albuquerque Operations Office, UMTRA Project Office, Albuquerque, New Mexico.

MKF (MK-Ferguson), 1991. Surveillance and Maintenance Subcontract Documents, Final Design for Construction, Lowman, Idaho, prepared by MK-Ferguson for the U.S. Department of Energy, 1991, UMTRA Project Office, Albuquerque, New Mexico. 
NRC (U.S. Nuclear Regulatory Agency), 1991. Letter to M. L. Mathews, UMTRA Project Manager, Albuquerque, New Mexico, NRC/UMT/0891-0056, from J. J. Surmier, Division of Low-Level Waste Management and Decommissioning, U.S. Nuclear Regulatory Commission, Washington, D.C.

TAC (Technical Assistance Contractor), 1985. UMTRA Technical Assistance Contractor Standard Operating Procedures, prepared by the Jacobs Engineering Group, Inc., for the UMTRA Project, Albuquerque, New Mexico.

\subsection{CODE OF FEDERAL REGULATIONS}

10 CFR 40, "Domestic Licensing of Source Material," Code of Federal Regulations, Vol. 10, Part 40, U.S. Nuclear Regulatory Commission, Office of the Federal Register National Archives and Records Administration, Washington, D.C.

40 CFR 192, "Health and Environmental Protection Standards for Uranium and Thorium Mill Tailings," Code of Federal Regulations, Vol. 40, Part 192, U.S. Environmental Protection Agency, Office of the Federal Register National Archives and Records Administration, Washington, D.C.

40 CFR 264, "Standards for Owners and Operators of Hazardous Waste Treatment, Storage, and Disposal Facilities," Code of Federal Regulations, Vol. 40, Part 264, U.S. Environmental Protection Agency, Office of the Federal Register National Archives and Records Administration, Washington, D.C.

41 CFR 101, "Federal Property Management Regulations," Code of Federal Regulations, Vol. 41, Part 101, General Services Administration, Office of the Federal Register National Archives and Records Administration, Washington, D.C.

\subsection{DOE ORDERS}

Order 5000.3B, "Occurrence Reporting and Processing of Operations Information," draft September 24, 1991, U.S. Department of Energy, UMTRA Project Office, Albuquerque Operations Office, Albuquerque, New Mexico.

Order 5400.1, General Environmental Protection Program, June 29, 1990, U.S. Department of Energy, Environmental Protection Division, Office of Environment, Safety and Health, Washington, D.C.

Order 5480.1B, Environment, Safety and Health (ES\&H) Program for DOE Operations, September 1986, U.S. Department of Energy, Safety Programs Division, Washington, D.C.

Order 5700.6C, Quality Assurance, U.S. Department of Energy, September 23, 1986, U.S. Department of Energy, Office of Nuclear Energy, Washington, D.C. 


\subsection{FEDERAL REGISTER}

52 FR 36000, EPA's Proposed Standards for Remedial Action at Inactive Uranium

Processing Sites with Groundwater Contamination, September 24, 1987, Federal

Register, Office of the Federal Register National Archives and Records

Administration, Washington, D.C.

55 FR 45591, Custody and Long-Term Care of Uranium and Thorium Mill Tailings Disposal

Sites, October 30, 1990, Federal Register, U.S. Nuclear Regulatory Commission,

Office of the Federal Register National Archives and Records Administration,

Washington, D.C.

\subsection{PUBLIC LAWS}

PL 95-604 (Public Law 95-604), 1978. Uranium Mill Tailings Radiation Control Act of 1978, 42 USC 7901, November 8, 1978, 95th Congress of the United States of America, Washington, D.C. 
15.0 LIST OF CONTRIBUTORS

The following individuals contributed to the preparation of this LTSP.

\begin{tabular}{ll}
\hline Name & Contribution \\
\hline A. Bennett (TAC) & Document review \\
M. Day (TAC) & Document review \\
J. Gibb (TAC) & Document review \\
J. Jones (TAC) & Technical editing, document review \\
J. Lommler (TAC) & Engineering \\
P. Martinez (TAC) & Document review, real estate \\
M. Miller (TAC) & Document review \\
R. Saar (TAC) & Document review \\
C. Silva (TAC) & Document coordination \\
E. Storms (TAC) & Hydrology \\
L. Ulland (TAC) & Document review \\
C. Yancey (TAC) & Document review, site manager \\
\hline
\end{tabular}


ATTACHMENT 1

SITE OWNERSHIP/CUSTODY DOCUMENTATION 


\section{LAND OWNEPSHIP DOCUMENTATION}

\section{GENERAL}

Remedial action for the Lowman uranium mill radioactive sands site consisted of consolidation and stabilization of the contaminated materials on site. The state of Idaho acquired the larger portion of the site, 37 ac $(15$ ha), from NWI Land Management Corporation. NWI Land Management Corporation gifted to the state of Idaho the site and all fixtures and personal property located at the site. The land acquired from NWI Land Management Corporation was to remain with the state of Idaho until the surface remedial action project at Lowman was completed. Once completed, transfer of the land to the custody of the U.S. Government, under the jurisdiction of the DOE, was to take place.

The state also acquired a parcel of land by purchase from the U. S. Forest Service, under the Small Tracts Act. The parcel, consisting of 4.32 ac $(1.75 \mathrm{ha})$, was required for the final disposal cell design and to provide a buffer zone to the disposal cell area. Purchase of this tract was in fee simple title. The subsurface mineral rights were obtained from the BLM through a transfer of jurisdiction.

The legal description of the disposal site is provided below and a plan view of the disposal cell is presented in Figure 2.3 of the Lowman LTSP. Upon execution of the transfer, the recorded information (instrument number and filing date) will be provided to the DOE UMTRA Project Office and incorporated into the final LTSP.

\section{DOCUMENTATION OF ACQUISITION}

A. Surface and Subsurface Acquisition

(1) Legal Description of the Disposal Site.

A parcel of land located in the Southeast $1 / 4$ of Section 27, the Southwest $1 / 4$ of Section 26, and a portion of H.E.S. No. 490; all in Township 9 North, Range 7 East, Boise Meridian; Boise County, Idaho; more particularly described as follows:

Beginning at a U.S. Forest Service Aluminum Cap marking the Section Corner common to Sections 26, 27, 34 and 35, T9 N., R7 E., B. M.;

thence, along the section line common to Sections 26 and $27, \mathrm{~N} 0^{\circ} 02^{\prime} \mathrm{O} 5^{\prime \prime}$ W 1342.53 feet to a Bureau of Land Management Brass Cap marking Corner No. 2 of said H.E.S. No. 490;

thence, leaving said section line, S $26^{\circ} 46^{\prime} 59^{\prime \prime} E 96.17$ feet to a point, being the REAL POINT OF BEGINNING;

thence, S $54^{\circ} 22^{\prime} 20^{\prime \prime} \mathrm{W} 369.09$ feet to a point;

thence, $S 72^{\circ} 38^{\prime} 46^{\prime \prime} \mathrm{W} 251.45$ feet to a point; 
thence, S 81"43'27"W 277.89 leet to a point:

Honce, N O"45'14"W 380.03 foet to a point;

thence, N $15^{\circ} 49^{\prime} 57^{\prime \prime} \mathrm{E} 696.42$ feet to a point;

thence, $N 88^{\circ} 38^{\prime} 10^{\prime \prime} \mathrm{E} 840.24$ teet to a point;

thence, $S 15^{\circ} 50^{\prime} 35^{\prime \prime} \mathrm{W} 769.22$ teet to the REAL POINT OF BEGINNING;

said parcel contains 18.08 acres, more or less;

This legal description was prepared from information supplied by Porter's Land Surveying to MK-Ferguson and does not necessarily reflect the actual ground location of the points described herein. A certified legal description will be provided to MK-Ferguson after a field survey is performed to verify the field positions of the offset corners to the points described in this legal description. A certified survey will be provided to supersede this information.

\section{TRANSFER OF FINAL DISPOSAL SITE}

Pursuant to the cooperative agreement between the state of Idaho and the DOE, the tracts described above shall be transferred to the Federal Government prior to licensing of the final disposal cell.

A letter to the Idaho Department of Health and Welfare, dated May 19, 1993, was submitted requesting the transfer of acquisition documents to the U.S. Army Corps of Engineers (USACE). The USACE will review the documents provided and request a final title opinion. They will then effectuate the transfer.

\section{REAL ESTATE FILES}

Real estate correspondence and related documents are maintained and filed by the DOE, Albuquerque Operations Office, Property Management Branch, Facilities and Property Management Division, Albuquerque, New Mexico, under the supervision of Corville J. Nohava, (505) 845-6450. 
ATTACHMENT 2

NRC CONCURRENCE AND LICENSING DOCUMENTATION 
U.S. Department of Energy

Agreement No. DE-FCO4-85AI20535

Appendix B, Remedial Action Plan

for Iowman, Idaho

The United states of Amarioa

Departmant of Enargy

State of Idaho

By: $\frac{\text { That }}{\text { Mark In Matthew }}$
Project Manager
Uranium Mili Tallings Remedial sotion

By8

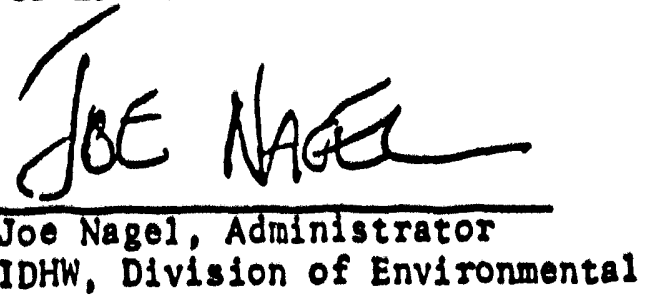
Quality

1410 N. Hilton

Bolse, Idaho $83720-9000$

Fleld office, Albugatargas

P.0. Box 5400

Aibuguergue, Ny 87215

Date: $7-|6-9|$

Date: $9-4 / 91$

CONOURRENCE:

NUCLIAR REOUIATORY COMISSION

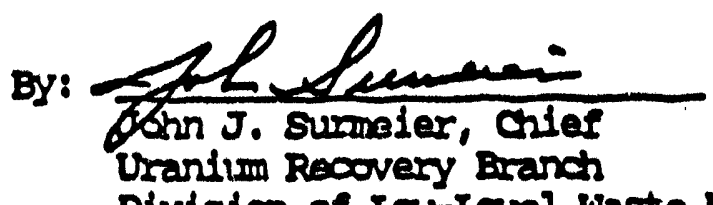

Division of Iow-Ievel Waste Maragement and Decomissioning

Date: $7-21-9$ 
UNITED STATES

NUCLEAR REGULATORY COMMISSION

WASHINOTON, D. C. 20555

JUL $3 \div 1991$

Mark L. Matthews, Project Manager

Uranium Mill Taflings Remedial Action

Project office

U.S. Department of Energy

A lbuquerque Operations Office

P.0. Box 5400

Albuquerque, New Mexico 87115

Dear Mr. Matthews:

The U.S. Nuclear Regulatory Commission (NKC) staff has completed its review of the final Remedial Action Plan and Site Design (RAP) and all associated documentation pertinent to the proposed remedial action for the uranium mill tallings site at Lowman, Idaho. Our review is documented in the Final Technical Evaluation Report (TER) (see Enclosure 1), which discusses the NRC staff's evaluation of the remedial action for compliance with the EHA standards.

In the groundwater area, the Lowman site is unique in that it does not have the outstanding open issue of postponed groundwater cleanup as a result of DOE's ability to demonstrate a lack of groundwater contamination at the site. Therefore, based on our review, the NRC can give full concurrence in the final Lowman Remedial Action Plan and Site Design. As a result, I have signed the original signature pages transmitted to the NRC for signature with Revision 3 to the RAP. The completed signature pages for the RAP are included as Enclosure 2.

DOE submitted RAP Modification (RAP MOD) No. 1 as Revision 2 to the RAP on April 22, 1991, for NRC staff review and concurrence. The RAP MOD requested the use of supplemental standards to prevent excessive environmental harm from the removal of residual radioactive material in the proposed remedial action tor Lowman. I he NRC staft reviewed and concurred in this RAP MOD on June 18, 1991. Our review of this RAP MOD has also been documented in the final TER and the signature pages for the RAP MUD are provided in Enclosure 3.

As you are aware, DOE also recently submitted to the NRC Revision B to the Remedial Action Inspection Plan (RAIP) (June 24,1991) for review and concurrence; and two Project Interface Documents Nos. $12-5-04$ and 12-S-05 (June 11, 1991) for review. As a result of our review of these documents, the NRC staff concurs in the RAIP and is in agreement with the classification of the PID NO. 12-S-04. The staff, however, does not agree with the Category II classification of PID No. 12-S-05 and will provide a complete discussion of our evaluation under separate cover at a later date. 
If you have any questions regarding the information in the enclosed final TER, please contact me at FTS $492-3439$ or the NRC Project Manager, S. L. Wastler, at FTS $492-0582$.

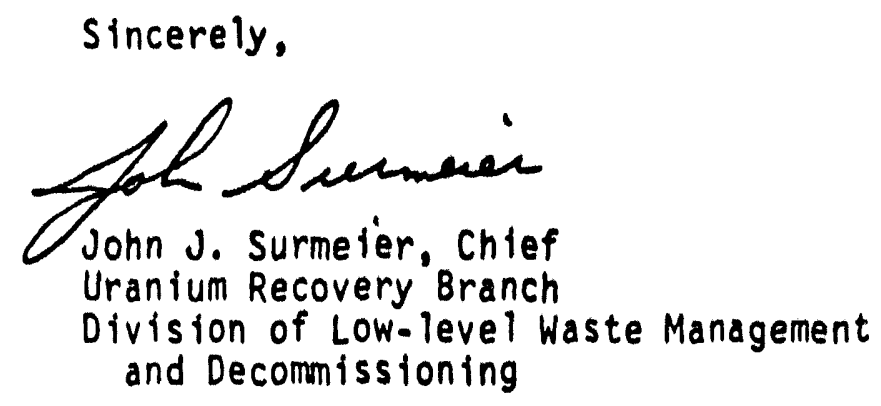

Enclosures: As stated

CC: P. Mann, DOE/AL

M. Abrams, DOE/AL

R. Donovan, Idaho

C. Cody, Idaho

K. Feldman, EPA 


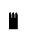

ATTACHMENT 3

PERMANENT SITE FILE INDEX

4 


\subsection{REPORTS}

1.1 Long-term surveillance plan

1.2 Environmental assessment and Finding of No Significant Impact

1.3 Disposal site characterization report

1.4 Final remedial action plan and final design for construction

1.5 Site certification report

1.6 Groundwater monitoring reports and records

1.7 Additional monitoring reports and records

1.8 Annual reports to the U.S. Nuclear Regulatory Commission

1.9 Annual inspection reports and records

1.10 Follow-up or contingency inspection preliminary assessments, reports, and records

1.11 Custodial maintenance or repair reports and records

1.12 Corrective action plans, reports, and records

\subsection{QUALITY ASSURANCE PROGRAM PLAN}

\subsection{DOCUMENTATION}

3.1 Licensing documentation

3.2 Disposal site legal description, title, custody documentation, or cooperative agreements

3.3 Interagency agreements, authorizations, and access agreements

3.4 Monitor well permits and well abandonment records

3.5 Pertinent design and construction documents

\subsection{DRAWINGS AND PHOTOGRAPHS}

4.1 Site atlas

4.1.1 Disposal site vicinity map

4.1.2 Disposal site topographic map

4.1.3 Disposal site map

4.1.4 Disposal site as-built drawings

4.1.5 Design and construction drawings

4.2 Baseline and aerial photographs 


$$
=
$$




\section{SITE INSPECTION PHIOTO LOG}

Site:

Site Activity:

Date:

Time of Day: From

to

Weather Conditions:

Roll Number:

Film Type:

Number of Exposures

Photo Number

Location (Azimuth)

Description
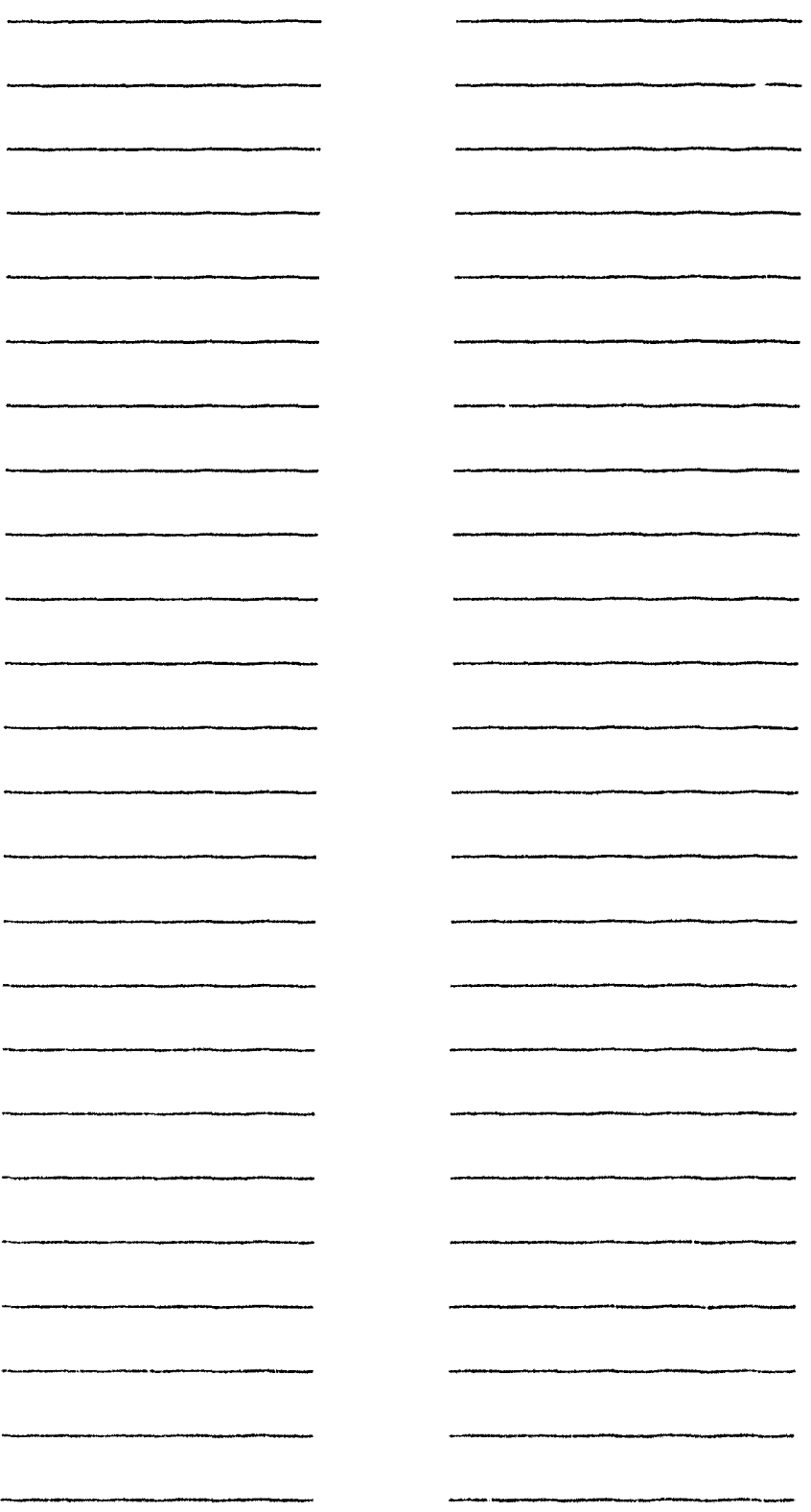


\section{SITE INSPECTION PHOTO LOG (CONT.)}

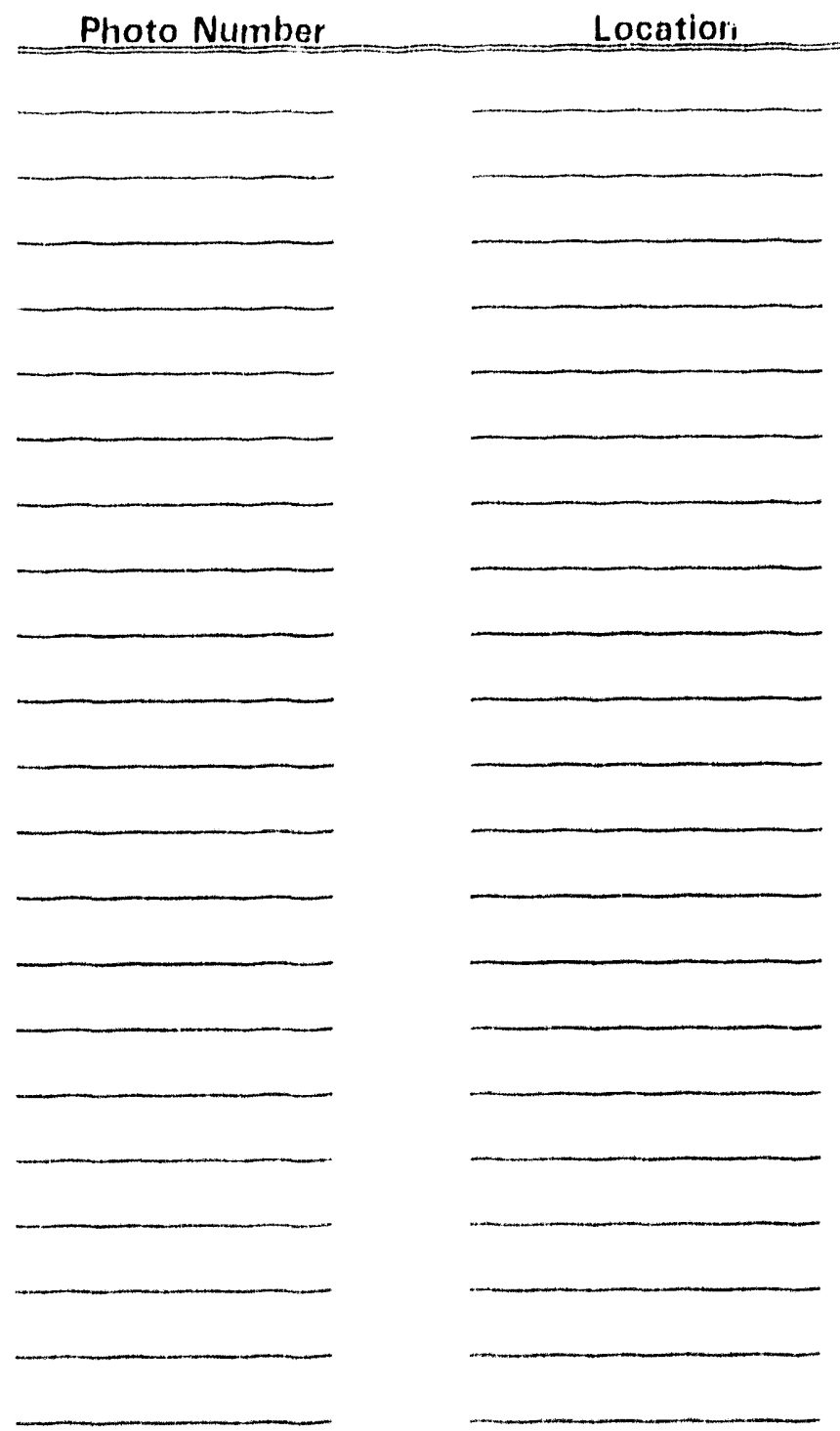

Photographer:

Printed Name

Description

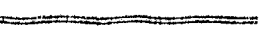


Site

Date
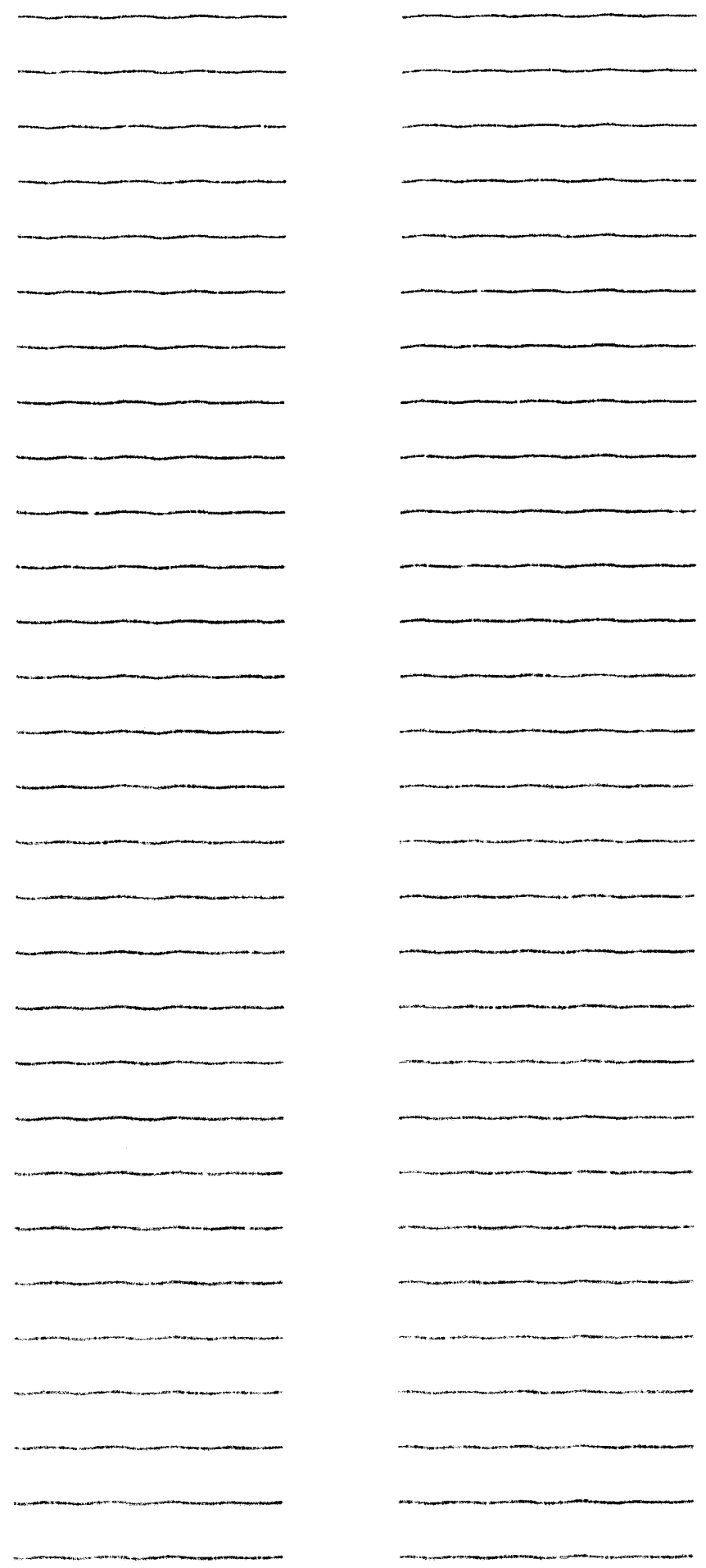


\section{SITE INSPECTION PHOTO LOG (CONT.)}

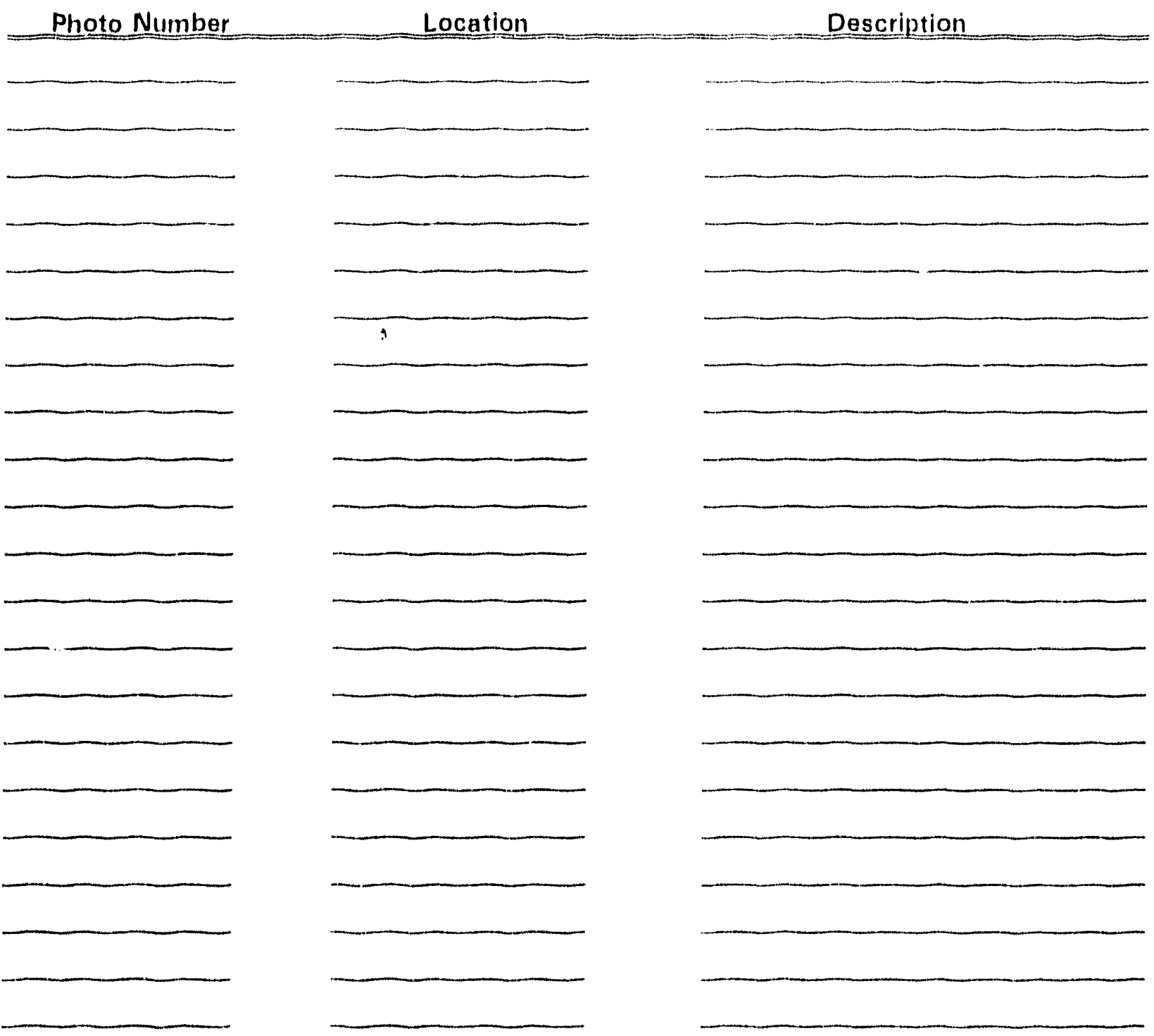


ATTACHMENT 5

INITIAL SITE INSPECTION CHECKLIST 


\section{SITE INSPECTION CHECKLIST FOR THE LOWMAN, IDAHO, URANIUM MILL RADIOACTIVE SANDS DISPOSAL SITE}

Date of Last Inspection:

Reason for Last Inspection:

Responsible Agency*:

U.S Department of Energy (DOE) Grand Junction Projects Office (GJPO)

Address: P.O. Box 2567, Grand Junction, Colorado $81502-2657$

Responsible Agency Official:

Inspection Start Date and Tirne:

Weather Conditions at Site:

Inspection Completion Date and Time:

Chief Inspector:

Name Title Organization

Assistant Inspector:

Name

Title

Organization

\section{A. GENERAL INSTRUCTIONS}

1. All checklist items must be completed and detailed comments made to document the results of the site inspection. The completed checklist is part of the field record of the inspection. Additional pages should be used, as necessary, to ensure that a complete record is made. Attach the additional pages and number all pages upon completion of the inspection.

2. Inspectors are to provide an up-to-date résumé or vitae for inclusion in the inspection report.

3. Any checklist line item marked by an " " that is checked by an inspector must be fully explained or an appropriate reference to previous reports provided. The purpose of this requirement is to provide a written explanation of inspector observations and the inspector's rationale for conclusions and recommendations. Explanations are to be placed on additional attachments and cross-referenced appropriately. Explanations, in addition to narrative, will take the form of sketches, measurements, and annotated site atlas overlays.

\footnotetext{
"Responsibility for site inspections assigned by DOE UMTRA Projeut Office, Albuquerque, to DOE GJPO, November 6, 1990.
} 
4. The site inspection is a walking inspection of the entire site, including the perimeter and sufficient transects to inspect the entire surface and all features specifically described in this checklist. Every monument, site marker, sign, monitoring well, and erosion control marker will be inspected.

5. A set of color print $35-\mathrm{mm}$ photographs is required. Sufficient photographs will be taken to compare to baseline photographs and determine if there are any significant differences in site appearance. In addition, all anomalous features or new features (such as changes in adjacent area land use) are to be photographed. A photo log entry will be made for each photograph taken.

6. Field notes taken to assist in completion of this checklist will become part of the inspection record. No form is specified; the field notes must be legible and in sufficient detail to enable review by succeeding inspectors and the responsible agency.

\section{B. PREPARATION (to be completed prior to site visit)}

1. License lincludes long-term surveillance and maintenance plan) reviewed.

2. Site as-built plans reviewed and base map with copies of the following site atlas overlays obtained:

a. Adjacent off-site features and land use; fences, gates, and signs; access roads and paths.

b. Survey boundary monuments, boundary monument, site markers, settlement plates, aerial photo ground controls, ground photo locations.

c. Monitoring wells, site drainage, diversion channels.

d. Planned inspection transects and vegetation cover.

e. Others.

These overlays will be used to identify site features and record, as appropriate, field data.

3. Previous inspection reports reviewed.
a. Were anomalies or trends in modifying processes detected on previous inspections?
b. Was a Phase II inspection conducted?
c. Was custodial maintenance performed? 
d. Was contingency repair work done as a result of the Phase II inspection?

4. Site custodial maintenance and contingency repair records reviewed.

a. Has site contingency repair resulted in a change from as-built conditions?

b. Are reviewed as-builts available that reflect contingency repair changes?

5. Adjacent property entry approval obtained lattach signed access agreement).

6. Aerial photos, if taken since last inspection, reviewed. For each set, enter date taken, scale, and if interpreted.

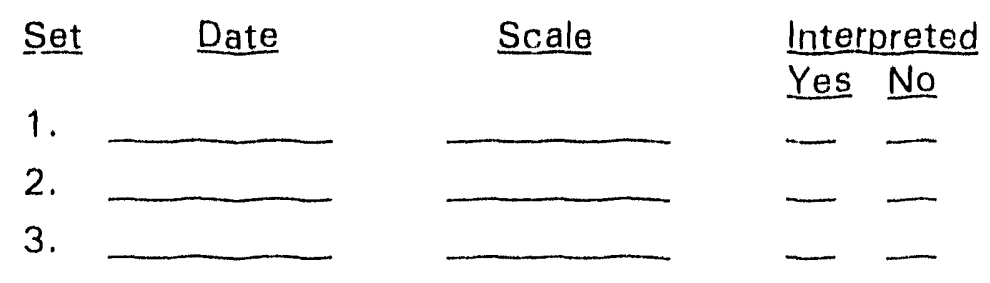

7. Were any of the following suggested by examination of aerial photographs? IIf yes, give photo set date and indicate if item noted by interpreter or inspector):

a. Intrusion by man?

b. Intrusion by animals?

c. Channelized erosion on slopes?

d. Change in area drainage?

e. Landslides?

f. Creep on slopes?

g. Obstruction of diversion channels?

h. Bank erosion of diversion channels? 
i. Seeparge?

j. Cracking?

k. Change in vegetative cover?

1. Displacement of fences, site markers, boundary markers, or monuments?

$\mathrm{m}$. Change in adjacent land use?

n. Evidence of radioactive sands exposure or transport?

8. From as-builts, or subsequent inspection reports, note distance and azimuth from designated site location, such as a monument, to adjacent off-site features that could eventually affect integrity of site.

Off-site feature Site monument no. Distance Azimuth

1.

2.

3.

9. Assemble and check out the following equipment, as needed, to conduct inspections:

a. Cameras, film, and miscellaneous support equipment.

b. Binoculars.

c. Tape measure.

d. Optical ranging device.

e. Brunton compass.

f. Photo scale stick.

g. Erasable board.

h. Plant press, plastic bags for vegetation.

i. Keys to locks.

j. Bolt cutters.

k. Hand lens.

l. Clipboard.

m. Others. 


\section{SITE INSPECTION}

1. Adjacent off-site features / within 0.4 motor 10.25 mile) of site boundaryl

a. Have there been any changes in use of adjacent areas (grazing, construction, agriculture)?

b. Are there any new roads or trails?

c. Has there been a change in the position of nearby stream channels?

d. Has there been headward erosion of nearby gullies?

e. Are there new drainage channels?

f. Others?

2. Access roads and paths, fences, gates, and signs.

a. Is there a break in the fence?

b. Have any posts been damaged or their anchoring weakened?

c. Is there evidence of erosion or digging beneath the fence?

d. Does the gate show evidence of tampering or damage?

e. Is there any evidence of human intrusion?

f. Is there any evidence of large animal intrusion?

g. Have any signs been damaged or removed? (Number of signs replaced:

h. Are access roads and paths passable?

i. Others? 
3. Monmments and other permanent features.

a. Have the survey or boundary momuments boun defaced or disturbed?

b. Have the site markers been disturbed by man or natural processes?

c. Do natural processes threaten the integrity of any monument or site marker?

d. Others?

4. Crest

a. Is there evidence of uneven settling? (depressions, scarps)

b. Is there cracking?

c. Has the outer cover layer been breached?

d. Is there evidence of erosion?

1) By water? (rills, rivulets)

2) By wind? (pedestal rocks, ripple marks)

e. Is there evidence of animal burrowing?

f. Others?

5. Slopes.

a. Is there evidence of gradual downslope movement (creep)? (terraces, deflection of plants)

b. Is there cracking?

c. Can depressions or bulges on the slope be seen?

d. Has the outer cover layer been breached? 


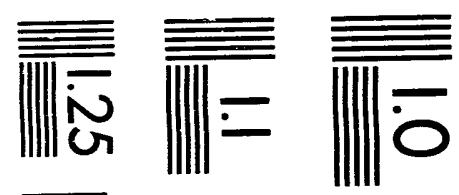

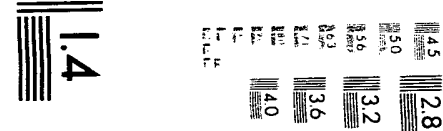

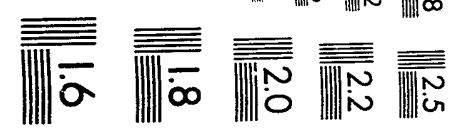



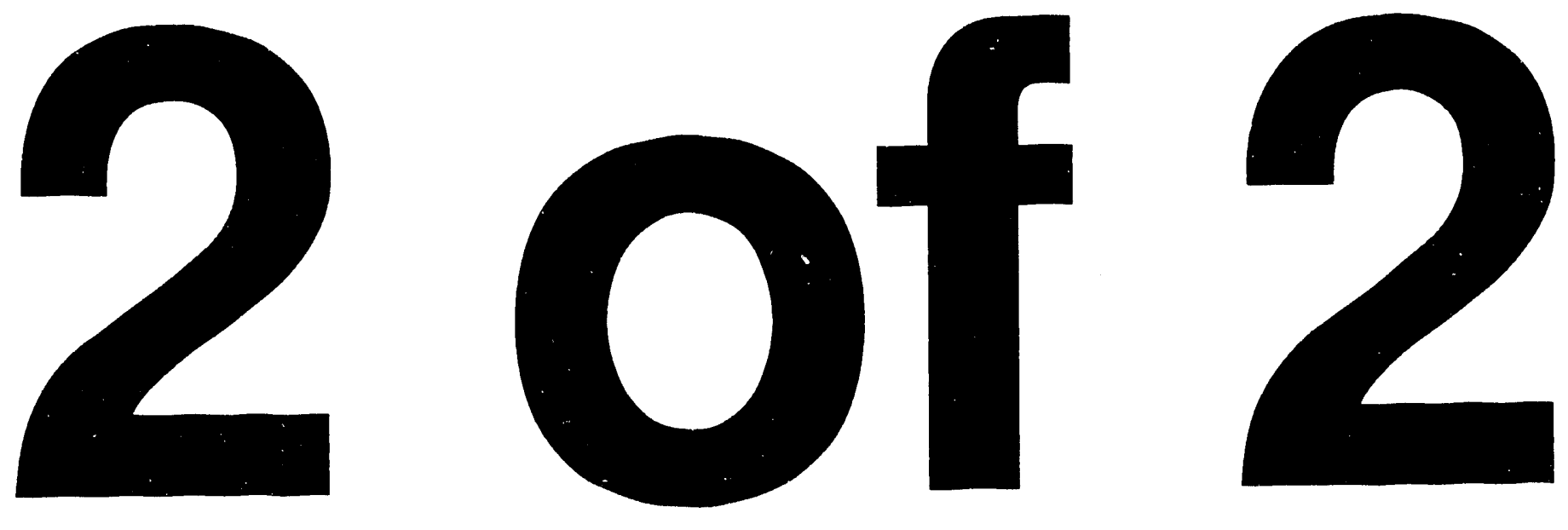
e. Is there evidence of erosion:

1) By water?

2) By wind?

f. Has water runoff become channelized? (rivulets, gullies)

g. Is there evidence of seepage? (moisture, color, vegetation)

h. Is there evidence of animal burrowing?

i. Is there evidence of deterioration of riprap or gravel cover?

j. Others?

6. Periphery (within site boundaries).

a. Is there evidence of seepage such as wet areas or localized change of vegetation?

b. Is there evidence of sediment transport from the radioactive sand pile by water or wind?

c. Is the vegetative cover as described in the as-builts?

d. Is the drainage as described in the as-builts?

e. Others? Burrowing animals; erosion.

7. Diversion channels.

a. Is there evidence of bank erosion?

b. Has the integrity of riprap structures been disturbed by people or natural processes?

c. Is there evidence of channel erosion?

d. Is there evidence of sedimentation in the channel?

e. Is the channel obstructed in any way? 


\section{E. CERTIFICATION}

I have conducted a prelicensing inspection of the Lowman uranium mill radioactive sands site in accordance with the procedures of the license (includes the site surveillance plan) as recorded on this checklist, attached sheets, field notes, photo log sheets, and photos.

Chief Inspector's Signature

Title
Printed Name

Date

(Stamp or Seal) 
ATTACHMENT 6

AGENCY NOTIFICATION AGREEMENTS 


\section{DRAFT}

September 10, 1993

Michael Butler

Boise County Sheriff's Dept.

Box 189

Idaho City, ID 83631

Dear Mr. Butler:

The U.S. Department of Energy (DOE) Uranium Mill Tailings Remedial Action Project Office is requesting notification of any unusual activities or events in or around the uranium tailings disposal cell located approximately 0.5 mile east of Lowman, Idaho. The purpose of the notification request is to assist the DOE in surveying and maintaining the integrity of its radioactive waste disposal cell, and to ensure public safety.

If during the course of routine activities, anything out of the ordinary is observed by your staff or reported to your office, we would appreciate immediate notification to the DOE Grand Junction Projects Office's 24-hour phone line at (303) 248-6070.

If the notification request discussed above is agreeable to you, please sign and return the attached reply letter for our records as soon as possible. 
Should you have any questions, please contact Woody Woodworth of my staff at (505)

845-6130. Thank you for your attention in this matter.

\author{
Albert R. Chernoff \\ Project Manager \\ Uranium Mill Tailings Remedial Action \\ Project Office
}

\title{
ARC/CS/pmg
}

Enclosure

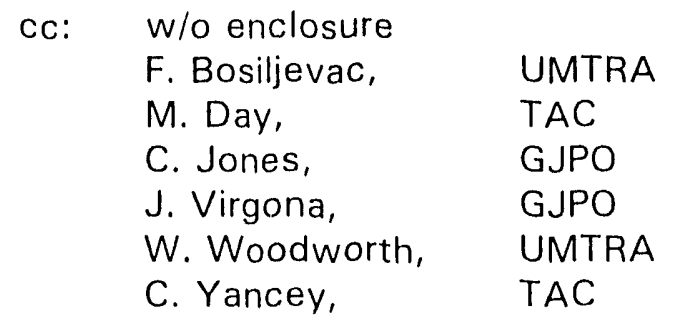




\title{
D R A F T
}

September 10, 1993

\author{
Albert R. Chernoff \\ UMTRA Project Manager \\ U.S. Department of Energy \\ Uranium Mill Tailings Remedial Action \\ Project Office \\ 5301 Central Avenue, N.E., Suite 1720 \\ Albuquerque, NM 87108 \\ Dear Mr. Chernoff:
}

This letter is to concur with the U.S. Department of Energy (DOE) request for notification as set forth in the DOE's letter of September 10, 1993. As requested in your letter, this office will contact the DOE's Grand Junction Projects Office at (303) 248-6070 if any unusual event or anomaly is observed or reported at the Lowman, Idaho, disposal site.

Sincerely,

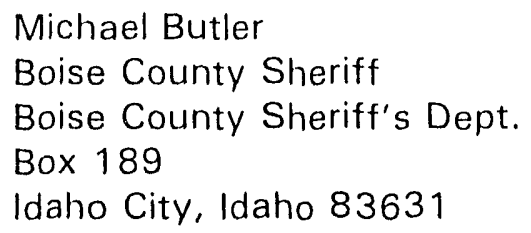

$\mathrm{MB} / \mathrm{CS} / \mathrm{pg}$

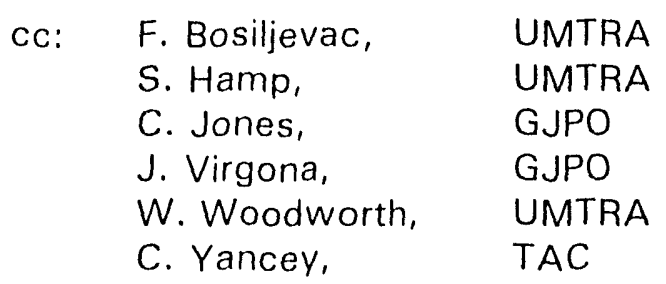




\section{R A F T}

September 10, 1993

Morris D. Huffman

Boise National Forest, Lowman Ranger District

HC77 Box 3020

Lowman, Idaho 83637

Dear Mr. Huffman:

The U.S. Department of Energy (DOE) Uranium Mill Tailings Remedial Action Project Office is requesting notification of any unusual activities or events in or around the uranium radioactive sands disposal cell located approximately 0.5 mile east of Lowman, Idaho. The purposes of this notification request are to assist the DOE in surveying and maintaining the integrity of its disposal cell and to ensure public safety. If during the course of routine activities, anything out of the ordinary is observed by your staff or reported to your office, we would appreciate immediate notification to the DOE Grand Junction Projects Office's 24-hour phone line (303) 248-6070.

If the notification request discussed above is agreeable to you, please sign and return the enclosed reply letter for our records as soon as possible. 
Should you have any questions, please contact Woody Woodworth of my staff at (505)

845-6130. Thank you for your attention in this matter.

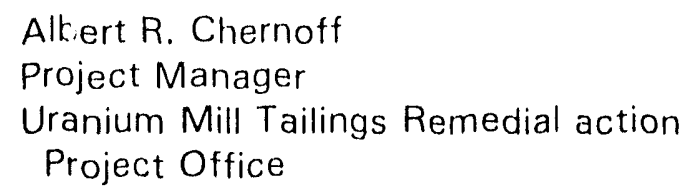

ARCiCS/pg

Enclosure

cc: W/o enclosure

F. Bosiljevac, UMTRA

M. Day, TAC

C. Jones, GJPO

J. Virgona, GJPO

W. Woodworth UMTRA

C. Yancey, TAC 


\title{
D R A F T
}

September 10, 1993

\author{
Albert R. Chernoff \\ UMTRA Project Manager \\ U.S. Department of Energy \\ Uranium Mill Tailings Remedial Action \\ Project Office \\ 5301 Central Avenue N.E., Suite 1720 \\ Albuquerque, NM 87108 \\ Dear Mr. Chernoff:
}

This letter is to concur with the U.S. Department of Energy (DOE) request for notification as set forth in the DOE's letter of September 10, 1993. As requested in your letter, this office will contact the Grand Junction Projects Office at (303) 248-6070 if any unusual event or anomaly is observed or reported at the Lowman, Idaho, disposal site.

Sincerely,

Morris D. Huffman

Boise National Forest, Lowman

Ranger District

HC77 Box 3020

Lowman, Idaho 83637

\section{$\mathrm{MH} / \mathrm{CS} / \mathrm{pg}$}
cc: F. Bosiljevac,
UMTRA
C. Jones,
GJPO
J. Virgona,
GJPO
W. Woodworth,
UMTRA
C. Yancey,
TAC 


\section{DRAFT}

September 10, 1993

John Jannuzzi

National Weather Service Office

3905 South Vista Avenue

Boise, Idaho 83705-0126

Dear Mr. Jannuzzi:

The U.S. Department of Energy (DOE) Uranium Mill Tailings Remedial Action Project is requesting receipt of notification in the event of issuance of flash flood or tornado warnings in Boise County, Idaho. We would appreciate notification to the DOE Grand Junction Projects Office's 24-hour phone line at (303) 248-6070 within 8 hours of issuance of a warning or episode of warnings.

The purpose of this warning is to assist us in surveying and maintaining the integrity of the radioactive waste disposal site located 73 miles northeast of Boise, Idaho.

If the notification request discussed above is agreeable to you, please sign and return the enclosed reply letter for our records as soon as possible. 
Should you have any questions, please contact Woody Woodworth of my staff at (505)

845-6130. Thank you for your attention in this matter.

Albert R. Chernoff

Project Manager

Uranium Mill Tailings

Remedial Action

Project Office

\section{ARC/CS/pg}

Enclosure

cc: W/o enclosure

F. Bosiljevac, UMTRA

M. Day, TAC

C. Jones, GJPO

J. Virgona, GJPO

W. Woodworth, UMTRA

C. Yancey, TAC 


\title{
D R A F T
}

September 10, 1993

\begin{abstract}
Albert R. Chernoff
UMTRA Project Manager

U.S. Department of Energy

Uranium Mill Tailings Remedial Action

Project Office

5301 Central Avenue N.E., Suite 1720

Albuquerque, NM 87108
\end{abstract}

Dear Mr. Chernoff:

This letter is to concur with the U.S. Department of Energy (DOE) request for notification as set forth in the DOE's letter of September 10, 1993. As requested in your letter, this office will contact the Grand Junction Projects Office at (303) 248-6070 if any unusual event or anomaly is observed or reported at the Lowman, Idaho, disposal site.

Sincerely,

John Jannuzzi

National Weather Service Office 3905 South Vista Avenue

Boise, Idaho 83705-0126

$\mathrm{JJ} / \mathrm{CS} / \mathrm{pg}$
cc:
F. Bosiljevac,
UMTRA
C. Jones,
GJPO
J. Virgona,
GJPO
W. Woodworth, UMTRA
C. Yancey,
TAC 


\section{R A F T}

September 10, 1993

Bruce Presgrave

U.S. Geological Survey

National Earthquake Information Center

P.O. 25046, Mail Stop 967

Denver Federal Center

Denver, Colorado 80225

Dear Mr. Presgrave:

The U.S. Department of Energy (DOE) Uranium Mill Tailings Remedial Action Project is requesting notification if a seismic event is recorded in Boise County, Idaho. The purpose of this request is to assist DOE in surveying and maintaining the integrity of its radioactive waste disposal site located approximately 0.5 mile east of Lowman, Idaho. (Latitude $44^{\circ}$ 05' O9" North / l.ongitude $115^{\circ} 36^{\prime} 30^{\prime \prime}$ West, T9N, R7E, Section 27)

We would appreciate notification to the DOE Grand Junction Projects Office's 24-hour phone line at (303) 248-6070 if a seismic event(s) occurs that fits any of the following descriptions:

- Any earthquake of magnitude 3.0 or greater, within 0.3 degree (about 20 miles) of the site;

- Any earthquake of magnitude 5.0 or greater, within 1.0 degree (about 70 miles) of the site.

If the notification request discussed above is agreeable to you, please sign and return the 
enclosed reply letter for our records as soon as possible.

Should you have any questions, please contact Woody Woodworth of my staff at (505)

845-5758. Thank you for your attention in this matter.

Albert R. Chernoff

Project Manager

Uranium Mill Tailings Remedial Action

Project Office

\section{$\mathrm{ARC} / \mathrm{CS} / \mathrm{pg}$}

Enclosure

cc: w/o enclosure

E. Artiglia, TAC

F. Bosiljevac, UMTRA

M. Day, TAC

C. Jones, GJPO

W. Woodworth UMTRA

J. Virgona, GJPO 


\title{
D R A F T
}

September 10, 1993

\author{
Albert R. Chernoff \\ UMTRA Project Manager \\ U.S. Department of Energy \\ Uranium Mill Tailings Remedial Action \\ Project Office \\ 5301 Central Avenue N.E., Suite 1720 \\ Albuquerque, NM 87108 \\ Dear Mr. Chernoff:
}

This letter is to concur with the U.S. Department of Energy (DOE) request for notification as set forth in the DOE's letter of September 10, 1993. As requested in your letter, this office will contact the Grand Junction Projects Office at (303) 248-6070 if any unusual event or anomaly is observed or reported at the Lowman, Idaho, disposal site.

Sincerely,

Bruce Presgrave

U.S. Geological Survey

National Earthquake Information

Center

P.O. Box 25046, Mail Stop 967

Denver Federal Center

Denver, Colorado 80225

$\mathrm{BP} / \mathrm{CS} / \mathrm{pg}$
cc:
F. Bosiljevac,
UMTRA
C. Jories,
GJPO
J. Virgona,
GJPO
W. Woodworth,
UMTRA
C. Yancey,
TAC 


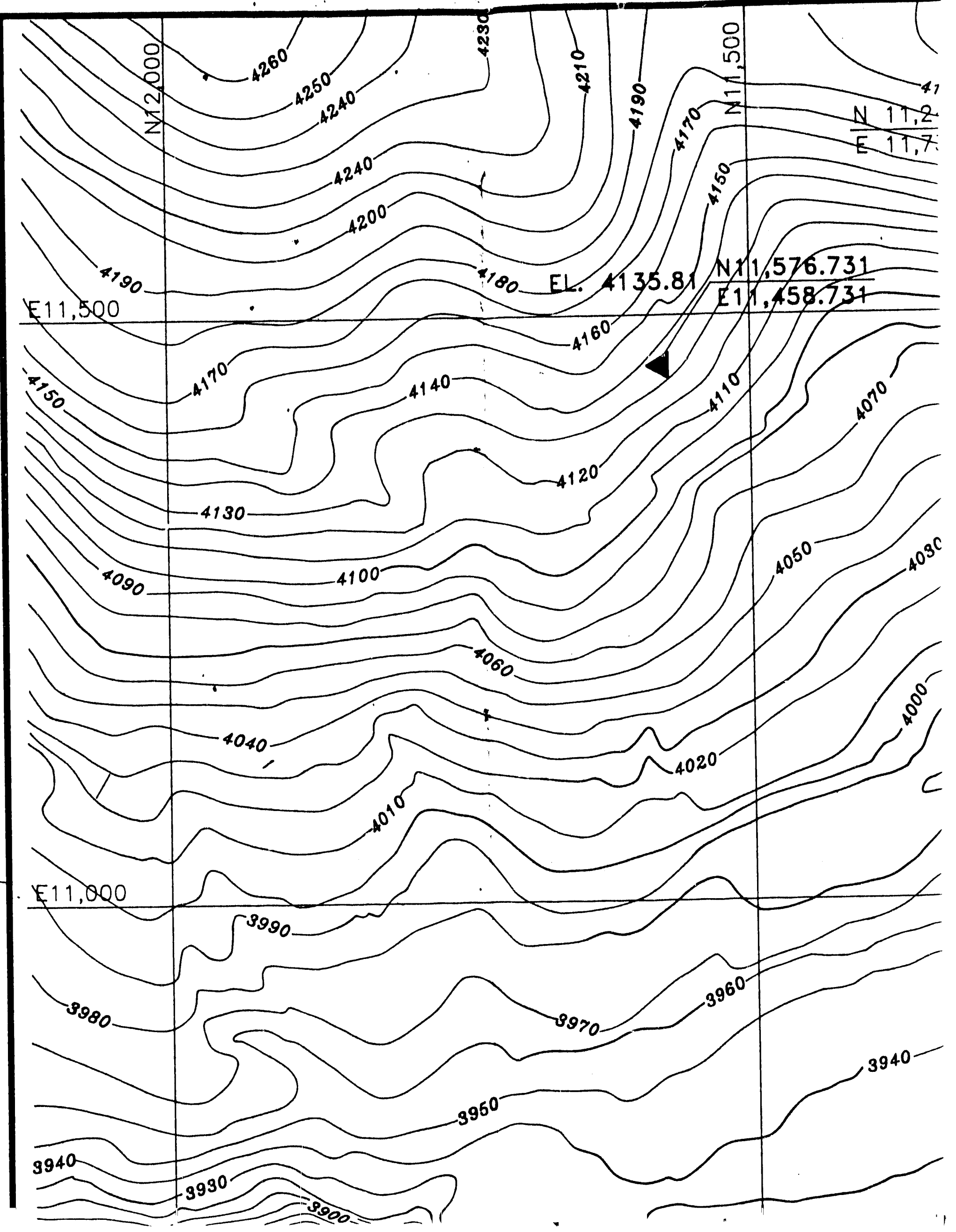




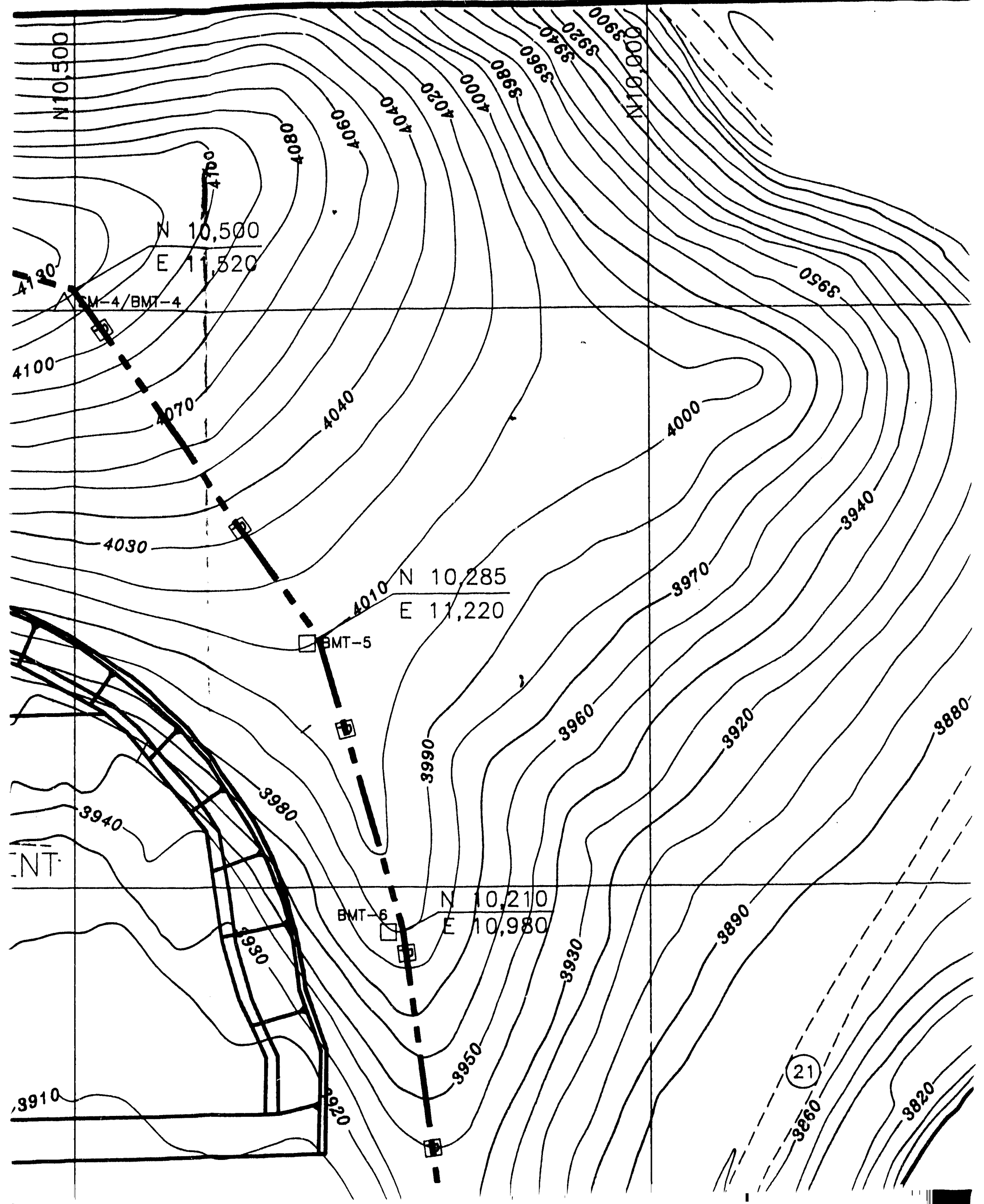




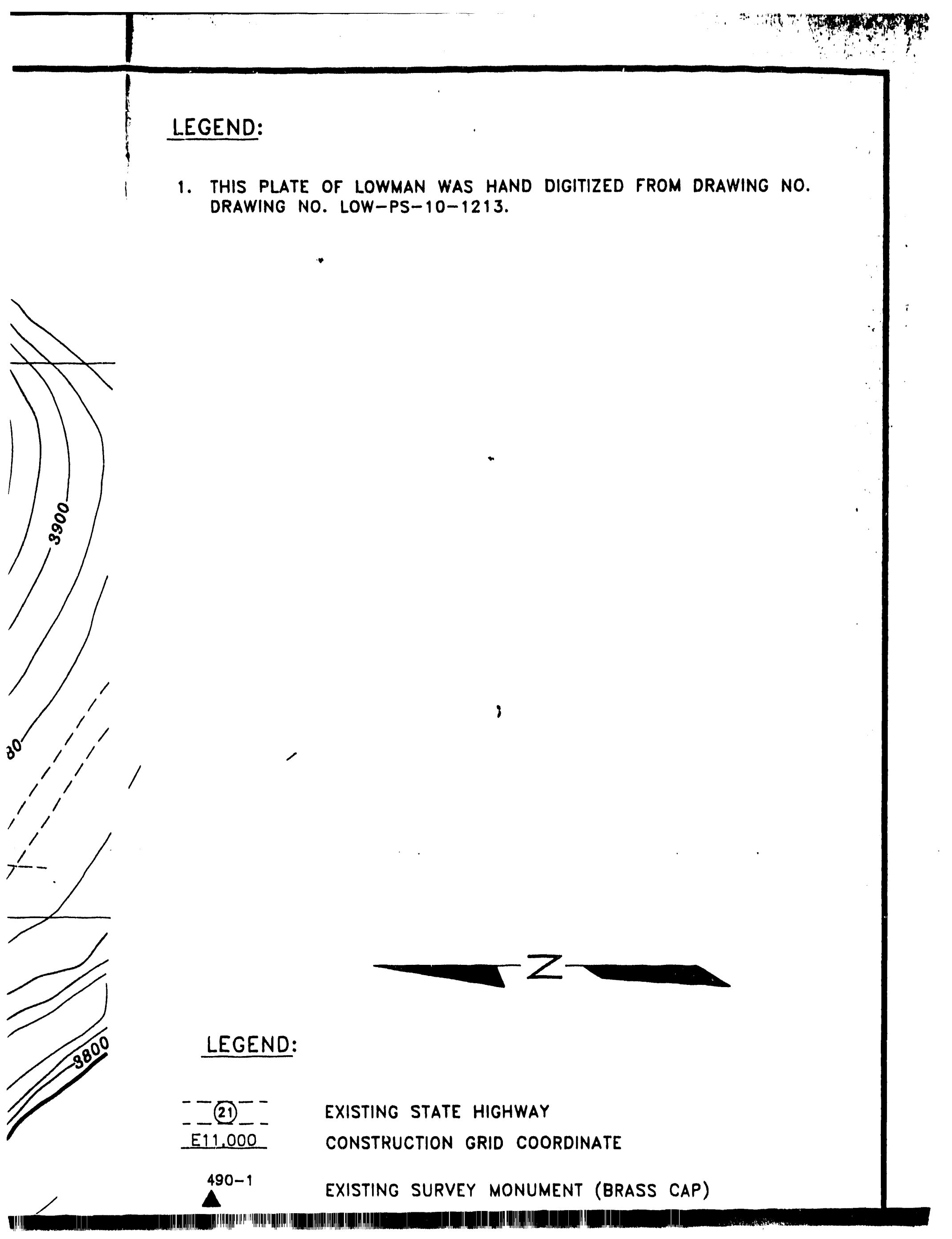




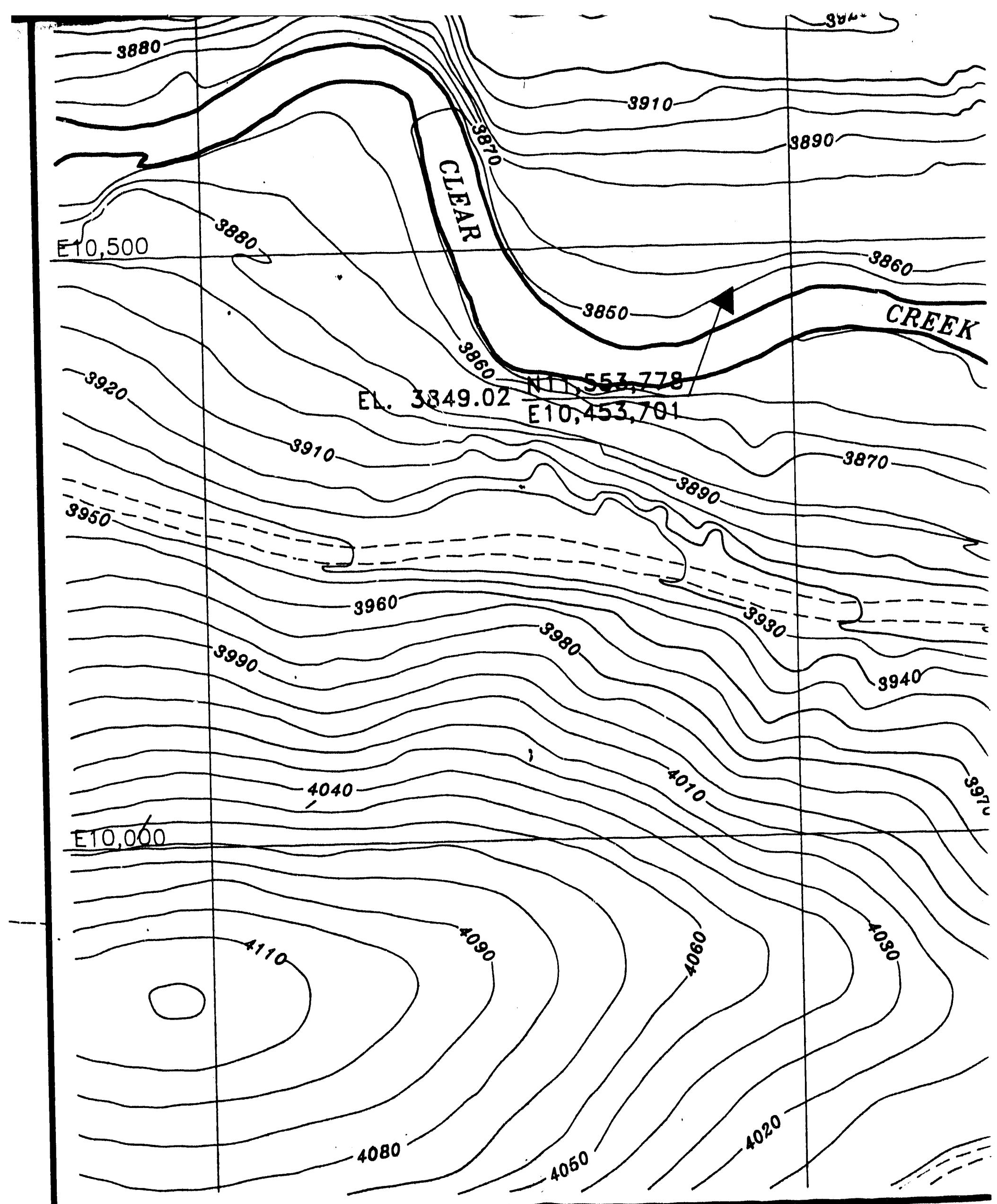




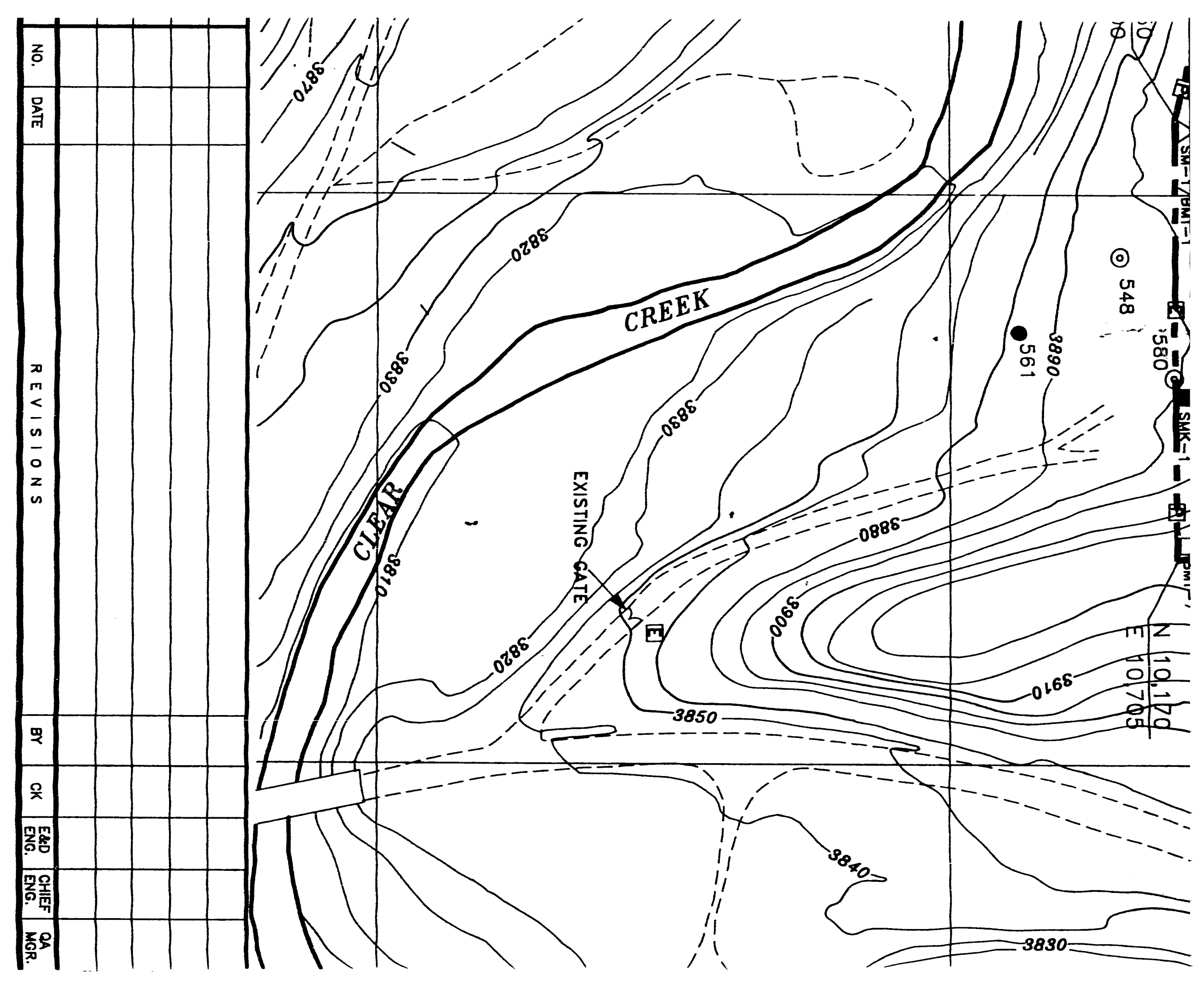




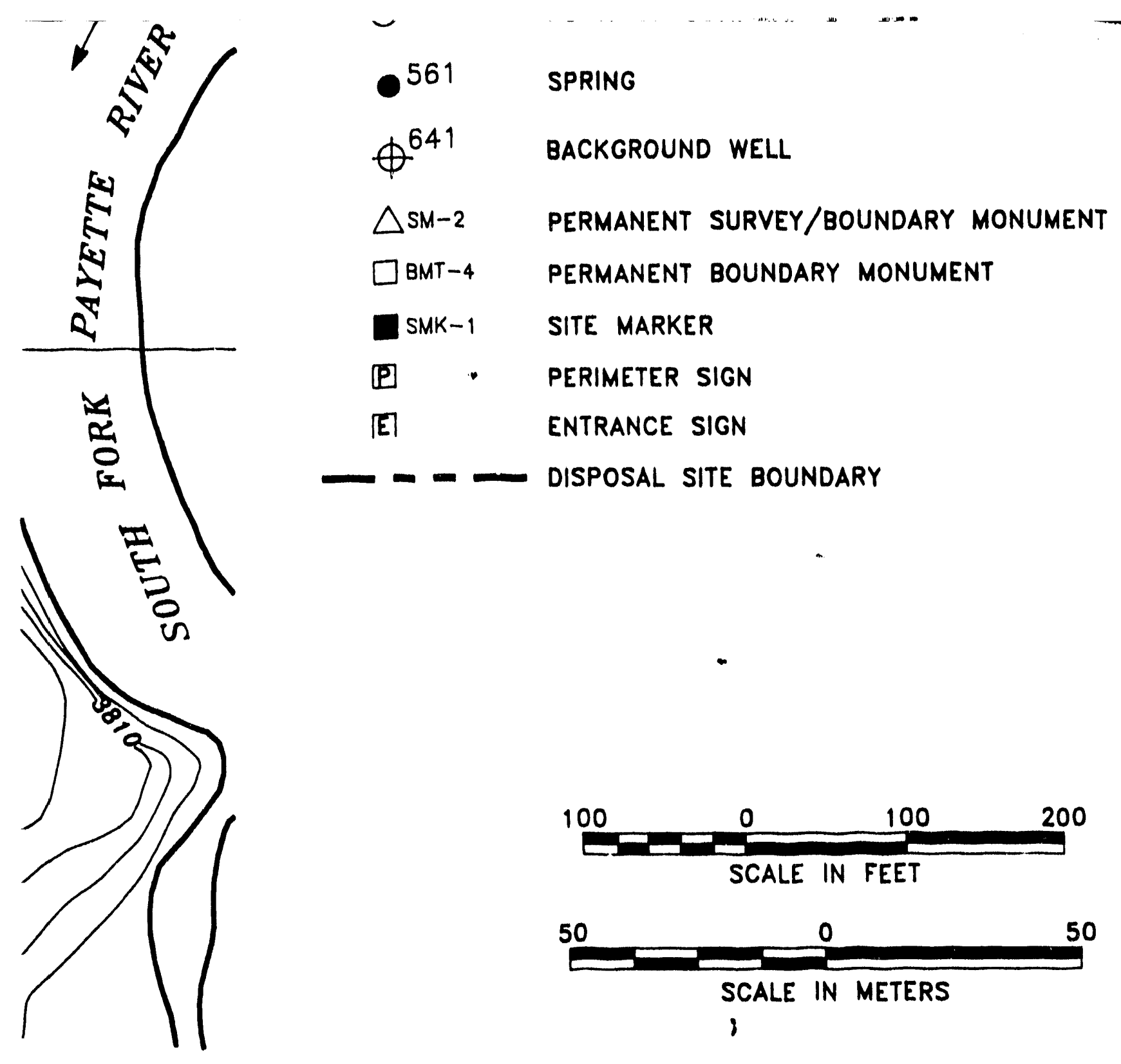

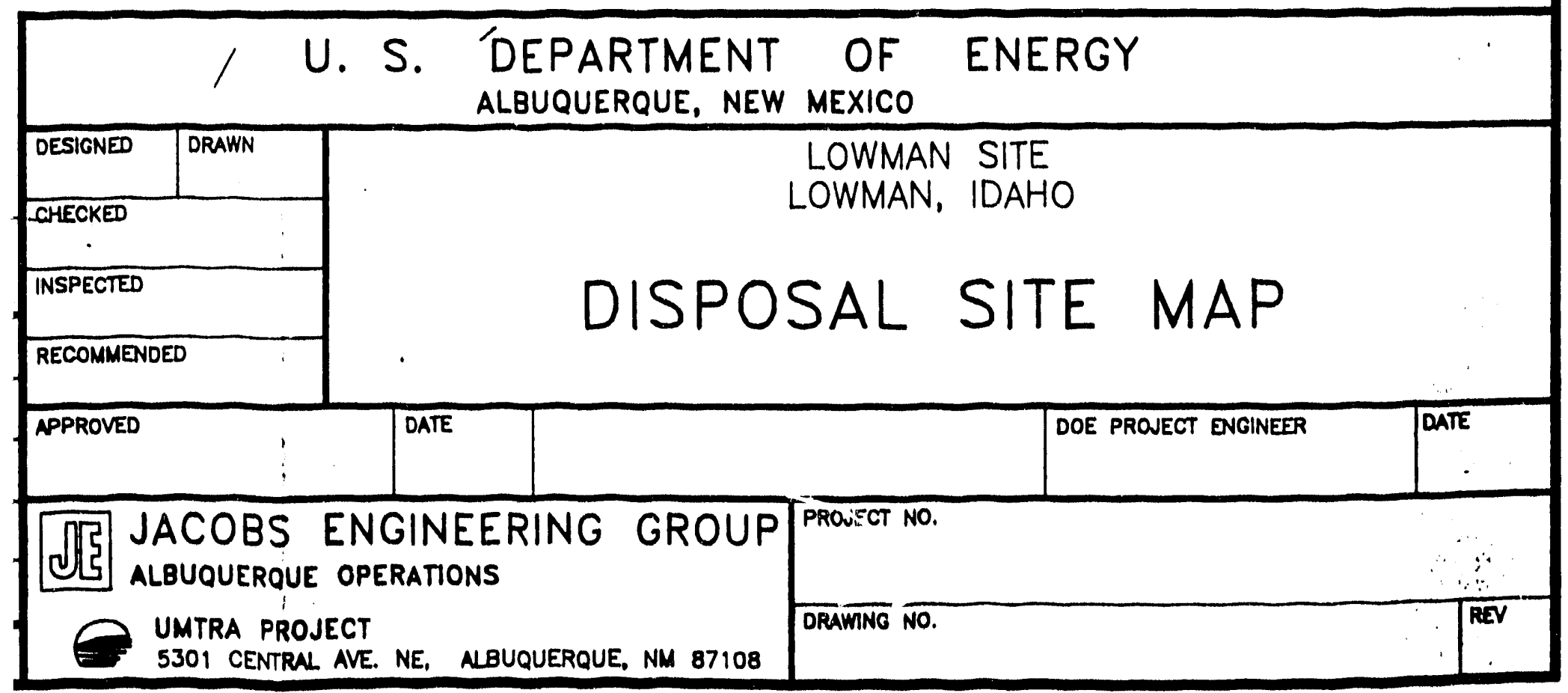



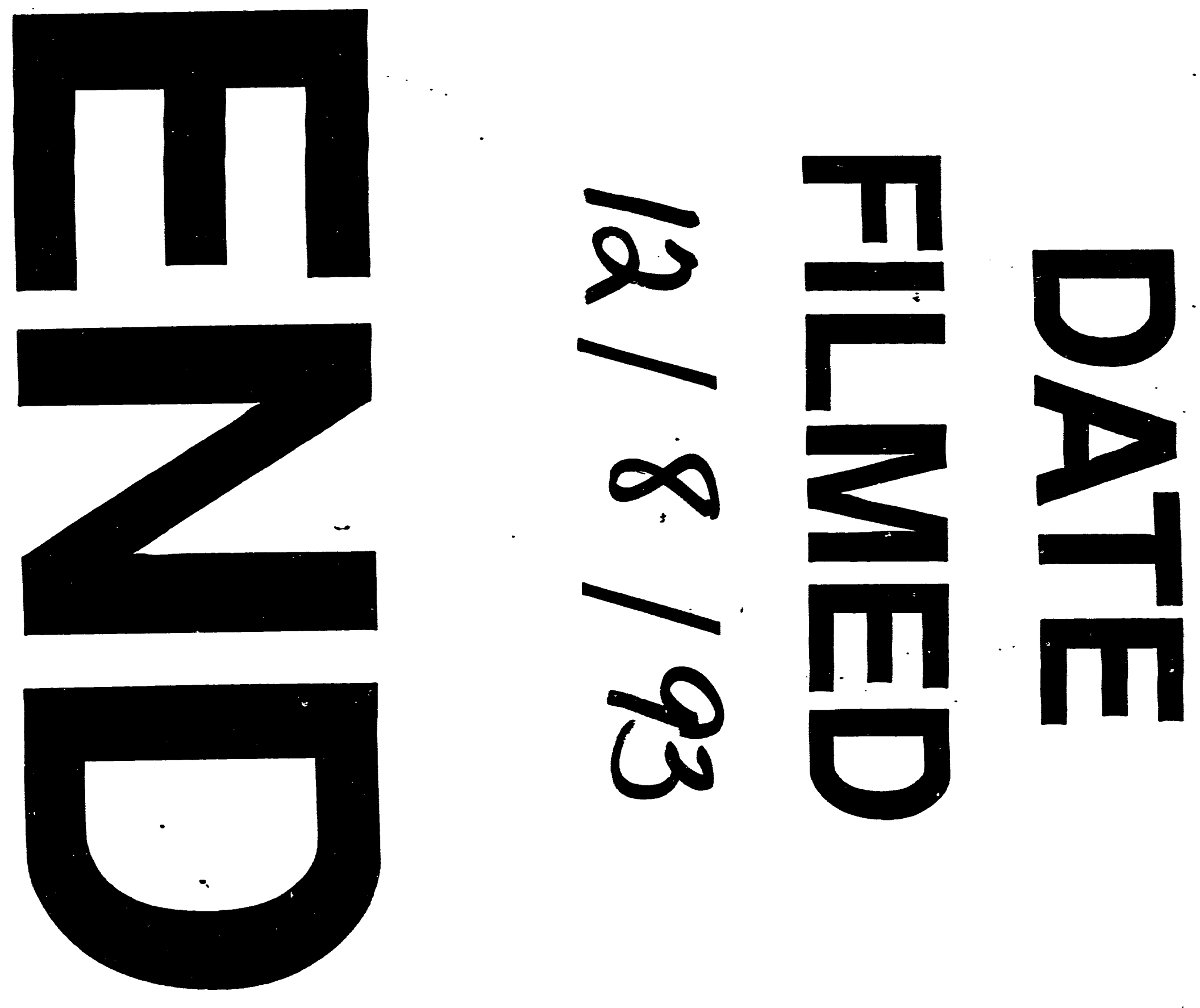

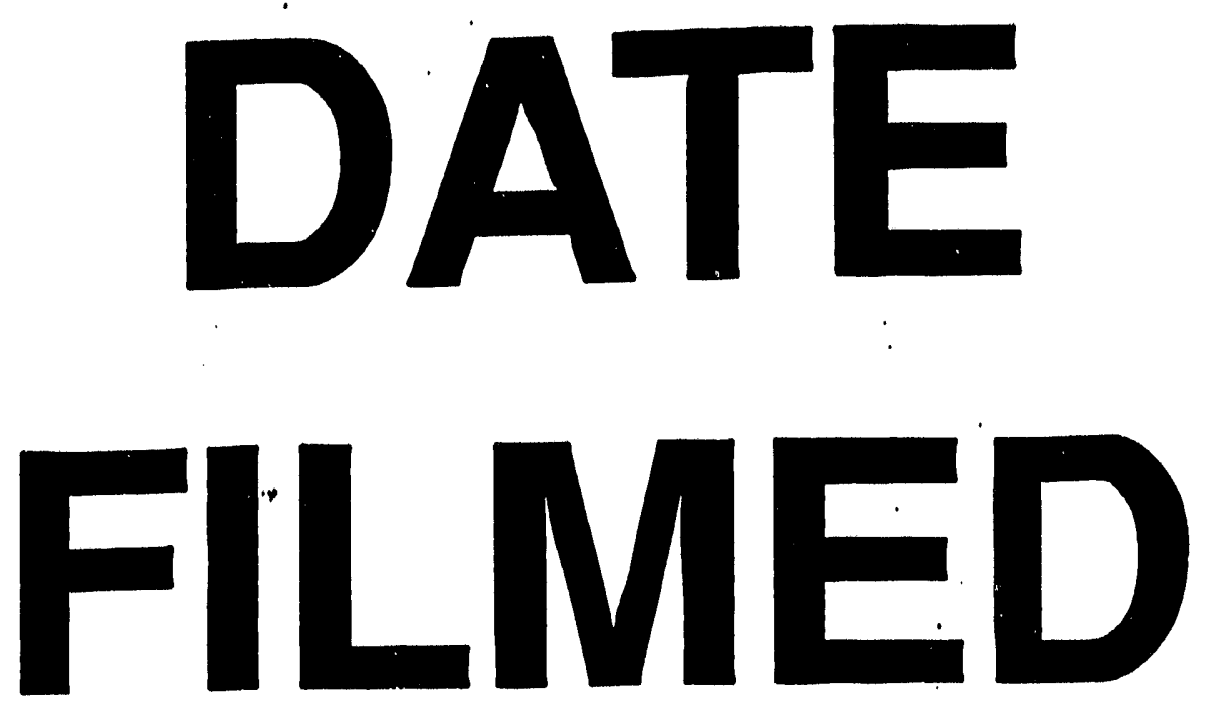

$12 / 8 / 93$
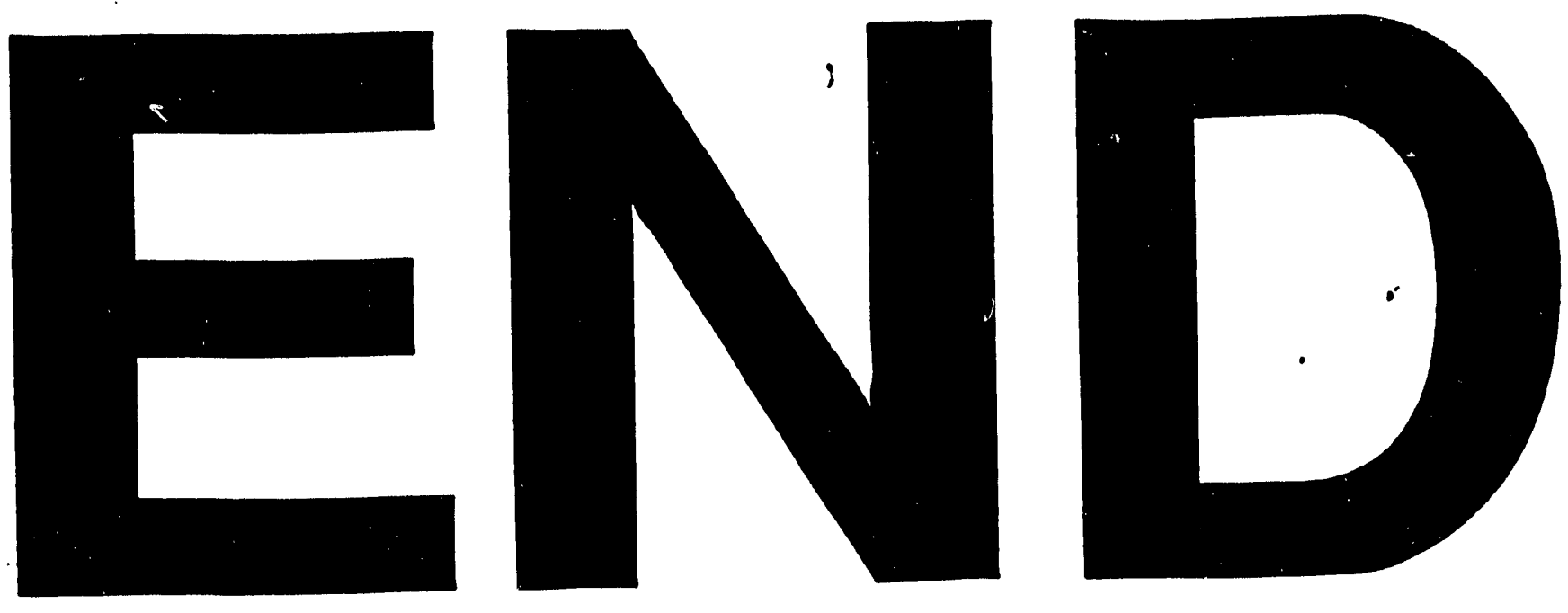
